Historic, Archive Document

Do not assume content reflects current scientific knowledge, policies, or practices. 

RETURN TO POMOLOGY

SECTION OD WOYE:CLATURE.

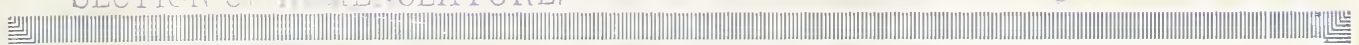

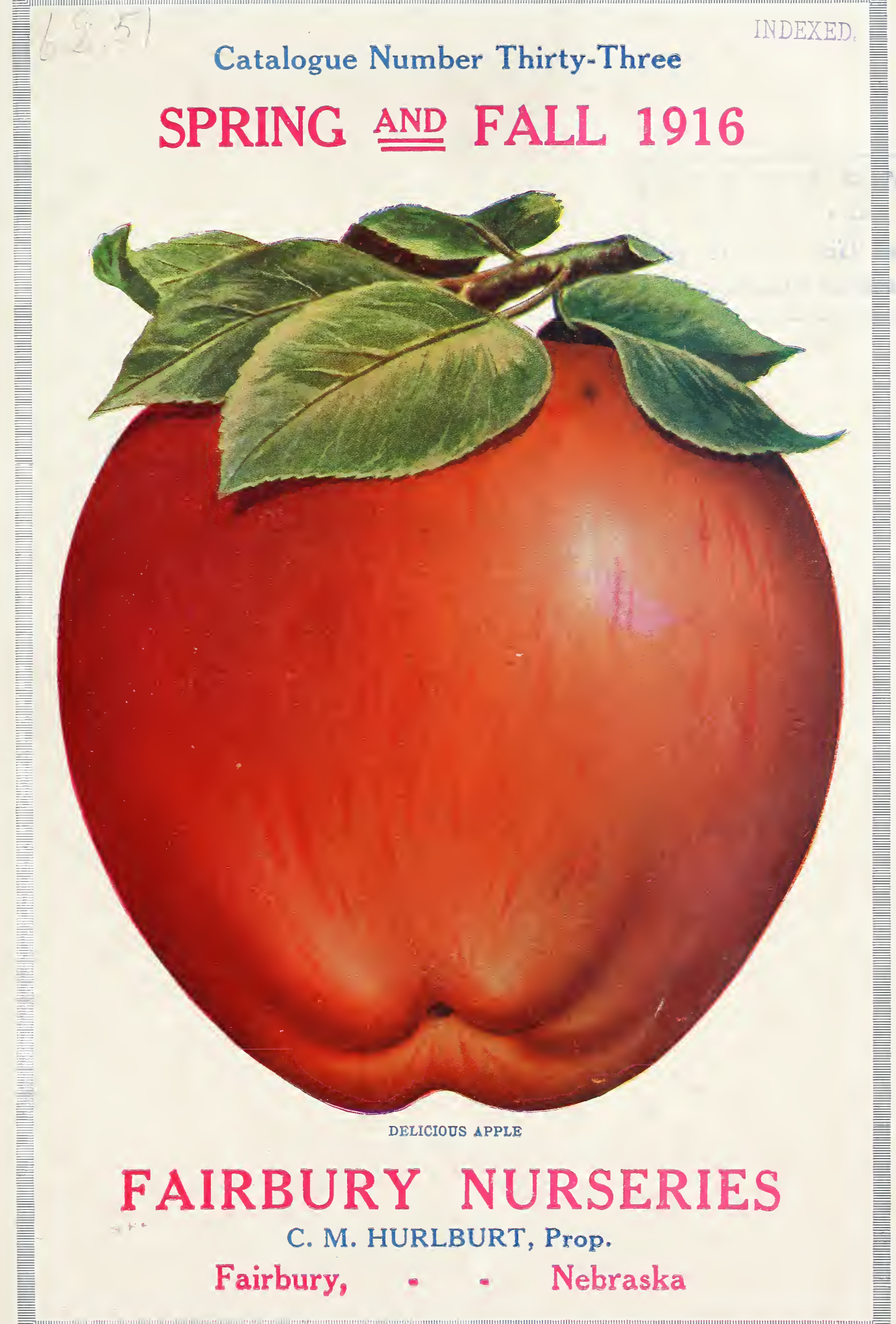

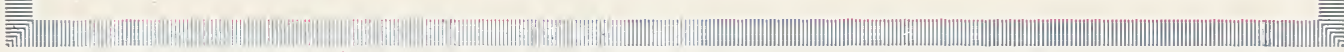




\section{Hanska Plum}

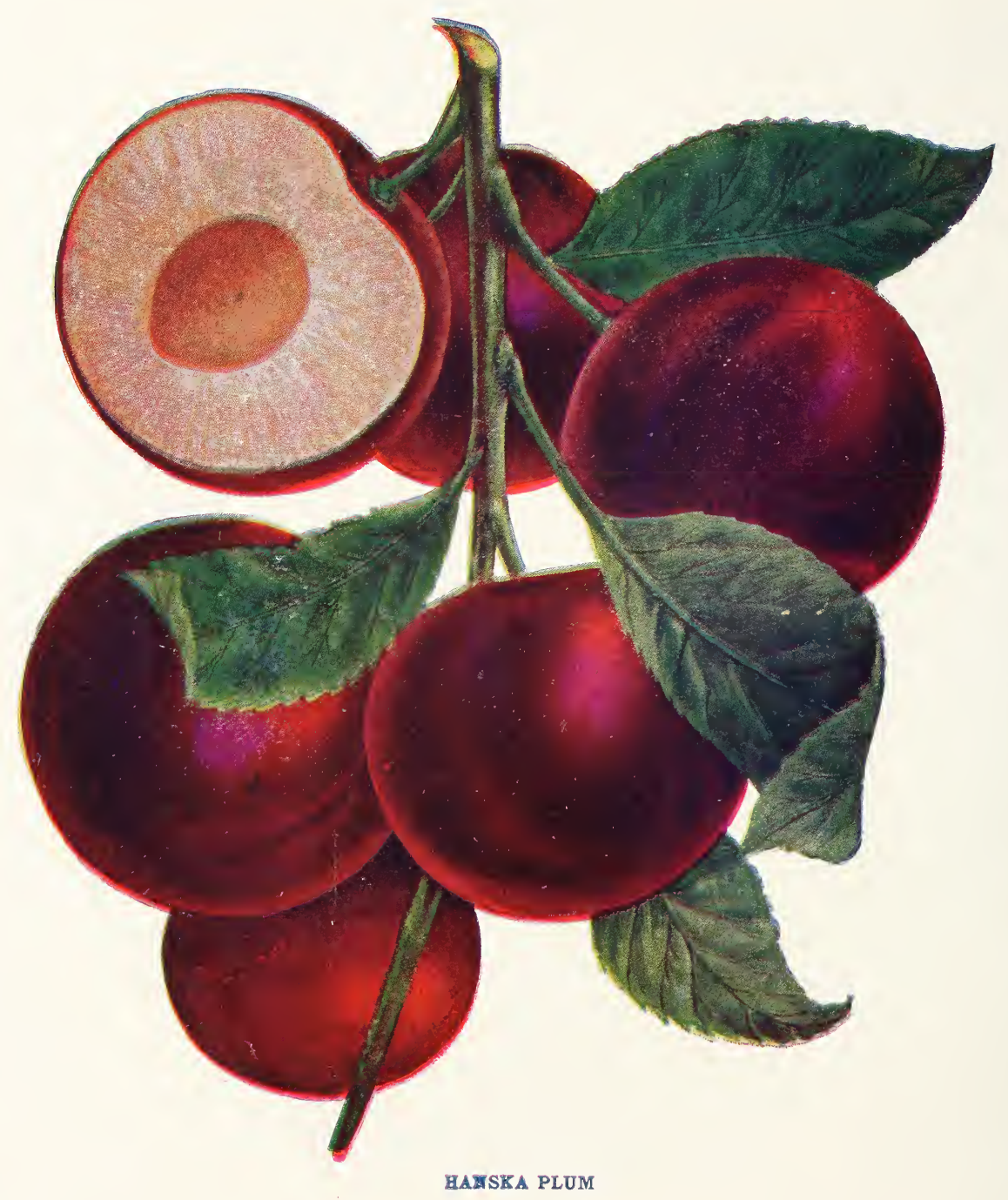

For description and prices see page 14 . 


\section{THE FAIRBURY NURSERIES, FAIRBURY, NEBRASKA}

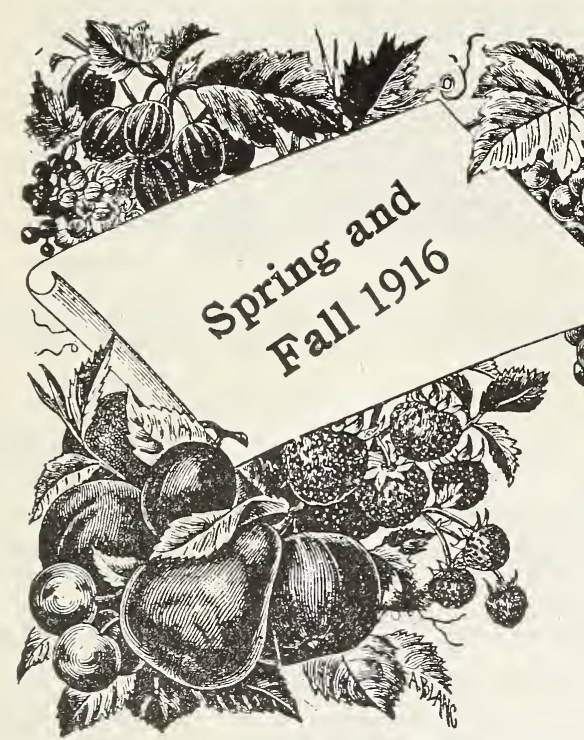

much lower than is often paid at other places for inferior stock.

No home can be completely satisfactory and beautiful without its fruit and friendly shade and flowers.

No city lot should be so small that it cannot make room for a tree, a clinging vine or an ornamental shrub.

No farm should be so large and so wholly given to crop production that it cannot give generous space to orchards and vineyards and all manner of small fruits; this, together with stately shade trees and beautiful flowers enhances the value of any real estate.

There is no food so healthful as fruit; no food so delicious, either in its fresh or preserved state, and none more easily produced. Then why not begin now to grow a variety on your own soil for your own benefit and have the added pleasure of being literally able to "Sit beneath your own vine and fig tree"?

This is now a day of specialties in all lines and we are specialists in the art of propagating nursery stock. We have made it our lifework and we know how to grow and cultivate, how to bud and graft and prune, in order to obtain shapely trees with good roots, and when you buy your stock from us you receive the benefit of our years of experience. We have hundreds of thousands of trees and plants of various sorts, and all in fine condition to ship to you at an early date in the spring.

We also have three greenhouses from which we can supply you with a general assortment of plants, such as the leading florists keep in stock.

It has been our aim in preparing this catalogue to make the descriptions and time of ripening as accurate and as intelligible as possible so our patrons may make selections suitable to their locality, and also that a succession of ripening, from the earliest to the lastest among the fruits and flowering among the ornamentals may be obtained, and we feel confident that no one can give you better service in your desire to beautify your home and grounds than we can.

We wish to express our sincere thanks for the generous patronage accorded us and to assure our customers, and those we hope to have as customers in the future, of our most careful and painstaking handling of the business intrusted to our care. 


\title{
WHAT WE DO
}

\begin{abstract}
We cultivate our trees in the most thorough manner and dig with the best improved tree digger, thus getting good length of roots.

We guarantee all trees, vines and plants to be in a good, healthy and growing condition

In packing we use paper lined boxes or bales, using plenty of wet moss and straw, thus preventing stock from becoming dry in transit; we make no charge for bales or boxes.

While we take the best of care in filling orders with stock true to name, should a mistake

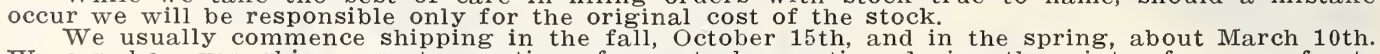
We can, however, ship a greater portion of our stock any time during the winter from our frostproof cellars; by this plan we can accommodate our customers who live in the South.

On receipt of an order we notify the customer at once by card; if after a reasonable length of time you do not hear from us, write us again; sometimes letters go astray.

In filling orders we send varieties called for as far as possible; for those varieties we are out of we substitute others in their place equally as good, unless you write us not to substitute.

We ship over the St. Joseph \& Grand Island, the C., R. I. \& P., and the B. \& M. railroads; over the American and Adams Express companies, and by Parcel Post.

See page 62 .
\end{abstract}

\section{TERMS}

In ordering, always give age or size and price of stock wanted; please be very particular in writing your name and address plainly.

Send cash with order, or good bank reference; if you wish stock sent C. O. D. by express, send one-fourth cash with order; we will then ship it and you can pay balance due to your express agent on receipt of stock.

All remittances should be made payable to C. M. Hurlburt; send by Postoffice or Express Money Order, Bank Draft, Check or Registered Letter. For amounts less than one dollar you may send one and two-cent stamps.

Our references are First National Bank or any business man in Fairbury, Neb.

\section{SPECIAL OFFERS}

We sell 5 trees at 10 rates, 50 trees at 100 rates, 500 trees at 1,000 rates.

On all cash orders, at prices in this catalog, sent us before March 1, 1916, we will allow 5 per cent discount. This offer is to induce you to order early.

Please notice that no discount is allowed after March ist. We make no deviation from this rule.

We prepay the freight to any railroad station in the United States, on single or club orders, for plants or trees amounting to $\$ 10.00$ or more, provided the full amount of the order is sent before shipment is made; should you prefer to have a $\$ 10.00$ order or more sent by express we will prepay as much on the expressage as the freight would amount to.

Do not make the mistake of making out a ten-dollar order, deducting from that amount the discount and due bill, and expect the freight to be prepaid; to secure prepaid freight, the order or total amount of club orders must be $\$ 10.00$ or more net.

Sometimes our railroad agents here fail to collect enough freight charges from us on prepaid shipments; should your agent require you to pay additional charges in such a case, send us the receipt he gave you, and we will return the money to you.

\section{INSTRUCTIONS TO PLANTERS}

Never buy trees of a traveling tree agent; as a rule they are not trustworthy, and will charge from two to ten times what the tree is worth.

Buy direct from some reliable nursery, or from a local nursery agent that you know to be honest. By this plan you will save money and have a source of redress in case there is anything wrong with your order.

It is a good plan to send in your order early, while the nursery's list of varieties is complete. Another thing, if you wait until late in the season, chances are that you will be so rushed with work that you will neglect to order at all, and thus lose a year's growth on your orchard.

As soon as trees are received the boxes or bundles should be unpacked and the roots of the trees soaked in a barrel or tank of water for twenty-four hours before planting; don't leave them in the water longer than this. If you are not ready to plant at once, they may be heeled in moist earth well packed around the roots.

In preparing ground, plow deep and pulverize the soil well before planting. Dig holes large enough so that roots of trees will have plenty of room; in planting, fill holes two-thirds full of loose soil, working it well among the roots as put in, then firm as solid as you can with the foot; fill remainder of hole with water; after it has soaked away fill up the hole with loose earth and do not firm it.

To heel-in trees in the fall for spring planting, select a spot where water will not stand after rains, make an incline of earth the length of the trees, the lower edge of which should be a foot below the surface of the ground, and the upper edge six inches above the surface. Now put the trees two inches apart on the incline with roots down; with a spade commence at lower edge of incline and dg out enough earth to cover trees all over; firm solid around the roots. You can now put in another layer of trees and proceed as before. See that the roots of last layer are covered at least one foot deep; if earth is not wet it should be well watered.

\section{Treatment of Trees that Have Been Frozen in the Packages or Received During Frosty Weather}

Put them unopened in a cellar or some other cool, protected place, free from frost, or cover them up heavily or entirely with earth until they are fully thawed out, when they can be unpacked and planted or placed in trenches until convenient to plant. Treated in this way they will not be injured by the freezing. 


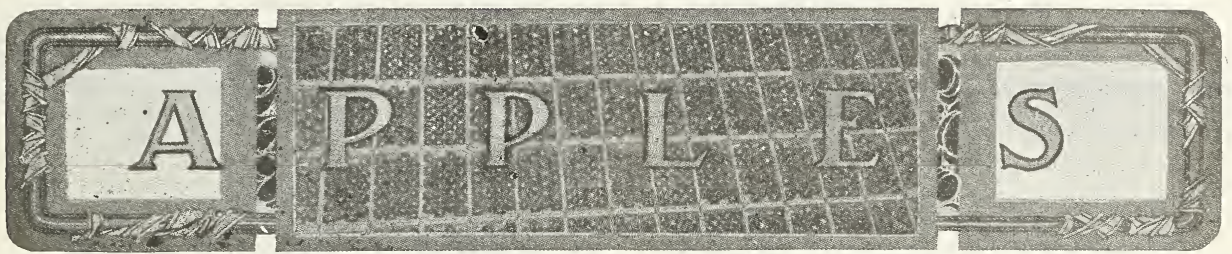

The first fruit in importance is the apple. Its period of ripening, unlike that of other fruits, extends nearly or quite through the year. By making judicious selections of summer, autumn and winter sorts, a constant succession can easily be obtained of this indispensable fruit for family use.

If apples are planted at the rate of fifty trees per acre, rows of peach trees can be planted between the apples, which, growing more quickly than the apple trees, soon protect them from winds, and thus prove a great benefit to them. After eight or ten years of productiveness, as the space is needed for the apples, the peach trees may be removed, leaving the orchard better for the protection, and at the same time having yielded the planter a large return for his outlay and labor.

We would advise you in planting an apple orchard to select those varieties which have proven hardy and productive in our western country. We give a brief description of varieties which we consider best suited for Kansas and Nebraska.

Note-We have a large stock of apple trees this year and have made prices very low; now is the time to buy apple.

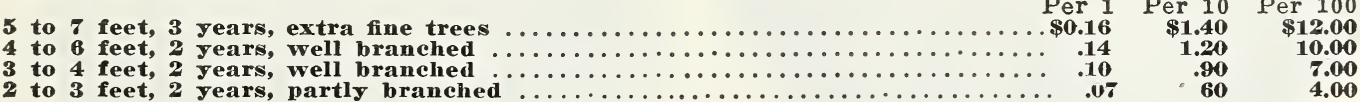

Other nurseries are charging higher prices on Delicious than on other varieties. We have a large stock of Delicious on hand and will furnish at same price, provided however, you do not select more than 30 per cent of that variety.

\section{Summer Varieties}

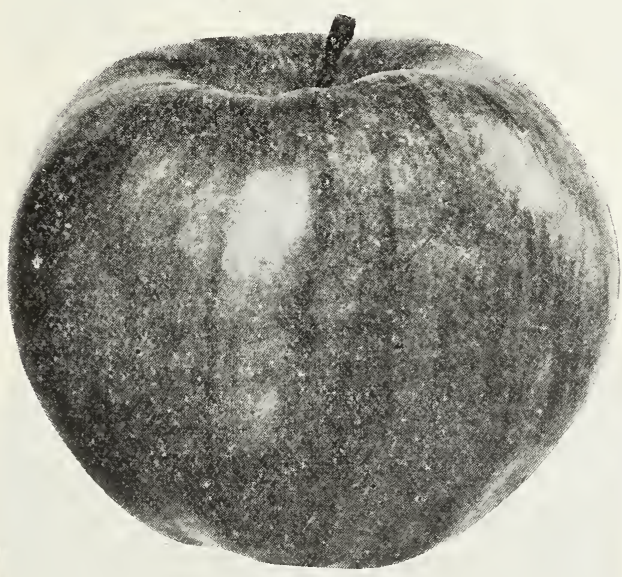

Duchess.

Carolina Red June. Tree hardy, upright, early bearer, shoots slender, foliage dark, color red, almost black in sun, fruit medium, form variable, surface smooth with minute dots.

Duchess of oldenburg. Tree rather poor in nursery, but has proven one of the best for the North; fruit large, surface smooth, waxen yellow ground covered with bright carmine stripes: sour; one of the very best for cooking; very productive. August.
Sweet June. Extra large yellow fruit, fine flavor, good for baking.

Early Harvest. Fruit medium size, greenish yellow, tender and juicy. First to ripen in July.

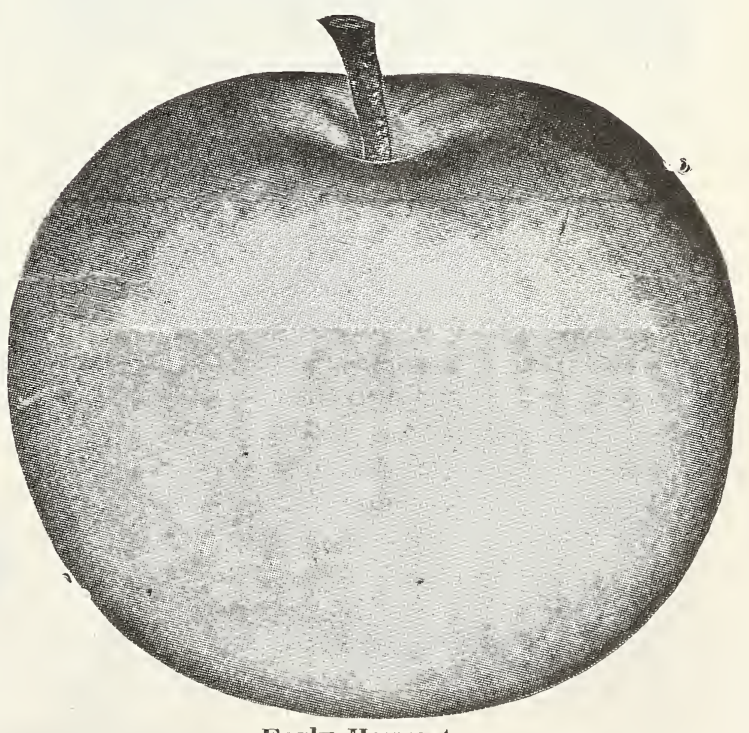

Early Harvest.

For Parcel Post prices see page 6. 
Red Astrachan. Fruit large, beautiful, deep crimson, crisp, juicy and of good quality. A hardy Russian variety. Splendid market sort. August.

Yellow Transparent. One of the earliest apples. Fruit is medium large, smooth, transparent. Skin is clear white, turning pale yel- low when ripe. Flesh white, fine grained, aromatic, and of splendid quality. Tree is vigorous, good bearer. Two-year-old trees frequently produce fruit. Succeeds well in all Eastern states, and should be planted in all cold climates. Succeeds well on thin soils. Ripens in early August. Its hardiness, vigor and early bearing commend it to planters.

\section{Fall Apples}

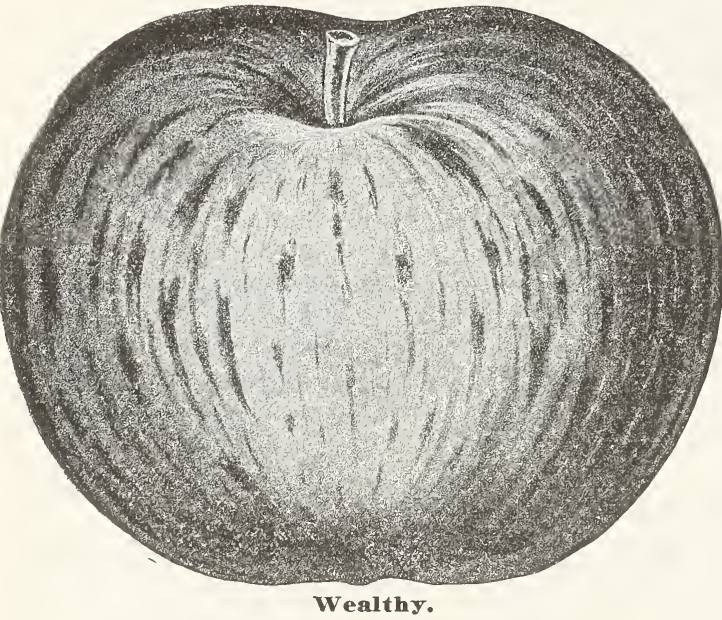

Maiden's Blush. Rather large, oblate, smooth, regular, with a fine, evenly shaded red cheek or blush on a clear pale yellow ground; flesh white, tender, sprightly, with a pleasant, subacid flavor; bears large crops. August and September.

Wealthy. A variety highly valued for its extreme hardiness at the far North. Tree is a thrifty grower and a good bearer. Fruit medium, roundish, skin is smooth, mostly covered with dark red, flesh white, fine grained, Juicy, sub-acid, good quality. Will keep till January. Extra good sort and splendid dessert and cooking apple. This is one of the few most desirable varieties for Minnesota, Wisconsin, Iowa and Nebraska, as well as the Eastern and Middle states.

Bismarck. Striped crimson over light yellow; fair quality tree dwarfish hardy and comes into bearing very young; good where one has but a small space to spare for apples, as they may be planted very close together. September.

Rambo. One of the best fall eating apples, green striped with red. September.

\section{Winter Apples}

Ben Davis (New York Pippin). Fruit medium to large, round, skin yellowish, splashed and striped and almost covered with red, flesh white, tender, moderately juicy, sub-acid, an excellent variety, tree very hardy, a free grower, coming into bearing early and very productive; it blooms late in the spring, thereby often escaping late frosts; very popular in the West and Southwest. December and March.

Jongthan. Beautiful tree, good grower, fruit rull medium, fair producer, color dark, shaded to almost black in sun, fruit drops in dry season. November and December, but can be kept until April.

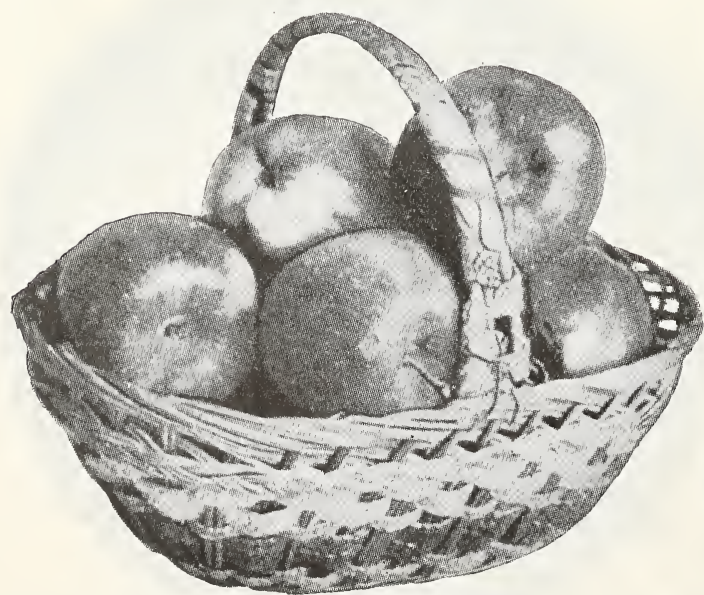

Winesap. Too well known to require a description. Tree hardy almost wherever planted, early bearer and profitable; tree inclined to overbear causing the fruit to be undersized; color red, sometimes almost black; flesh almost yellow, firm and crisp; one of the best. November to May.

.

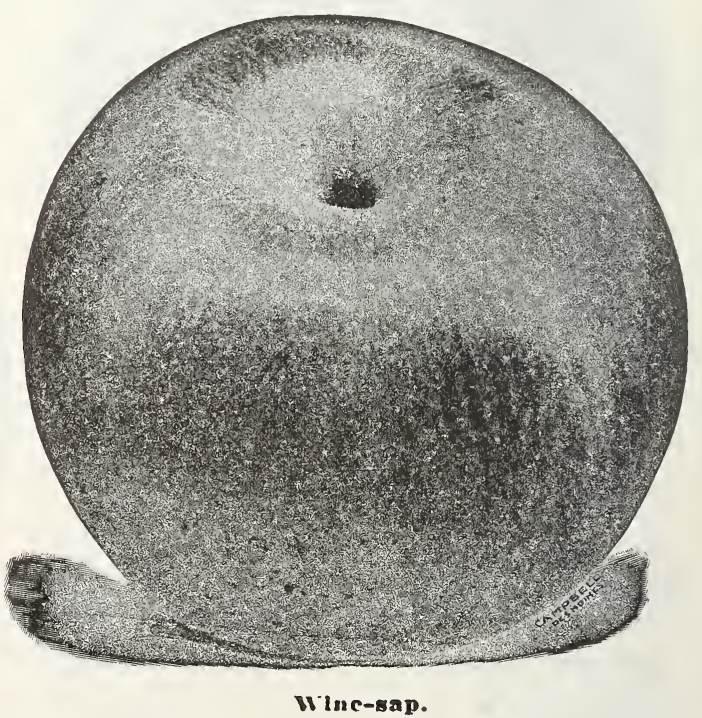

We pay the freight see page 4 . 


\section{WINTER APPLES-Continued}

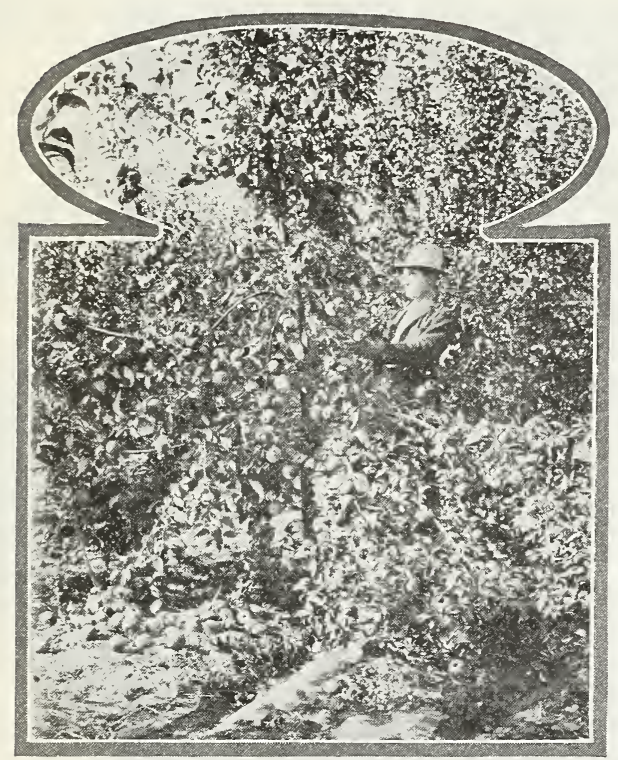

Missouri Pippin

Missouri Pippin. Tree resembles a seedling, good grower, foliage dense, fruit early, very productive; fruit medium, surface smooth shaded, mixed striped red; flavor sub-acid, very good; season, December to March.

Winter Banana. An excellent variety, which has stood the severest tests. Tree is hardy and will succeed in very cold climates, its wonderful productiveness will bring quicker and larger returns than any other apple in the orchard. The fruit has a richness in flavor that cannot be described. Surpasses in aromatic taste the choicest pear. Flavor very rich, spicy and aromatic. Flesh golden yellow, fine grained, firm and juicy. Tree a very strong grower, and will grow to be of immense size, suitable for lawn or shade tree, the leaves being nearly double the size of other sorts.

Delicious. Fruit is large, with the surface almost covered with a most beautiful, brilliant

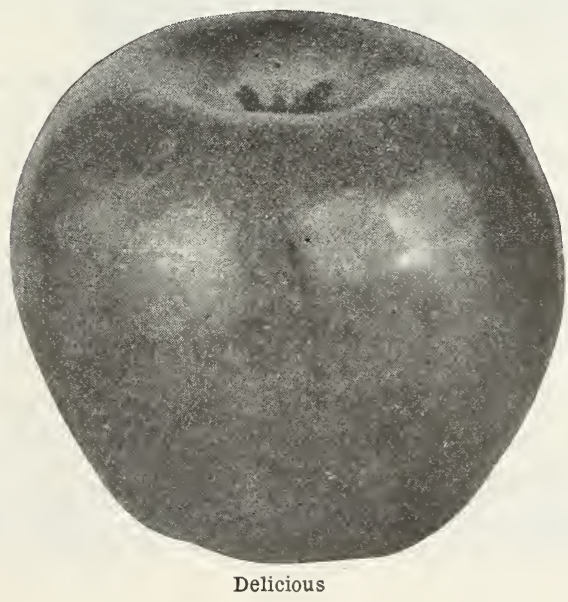

dark red, blending to golden yellow at the blossom end. In quality, it is unsurpassed, in flavor it is sweet, slightly touched with acid, but only enough so as to make it all the more pleasing, with an aroma delightfully fragrant. The flesh is fine grained, crisp, juicy, melting and withal delicious. In keeping quality, it ranks with the best, coming out of storage in March and April in perfect condition. Tree is very hardy. Delicious originated twenty years ago at Peru, Madison Co., Iowa, by the late Jesse Hiatt, and on his farm the original tree still flourishes, bearing annual crops of beautiful fruit.

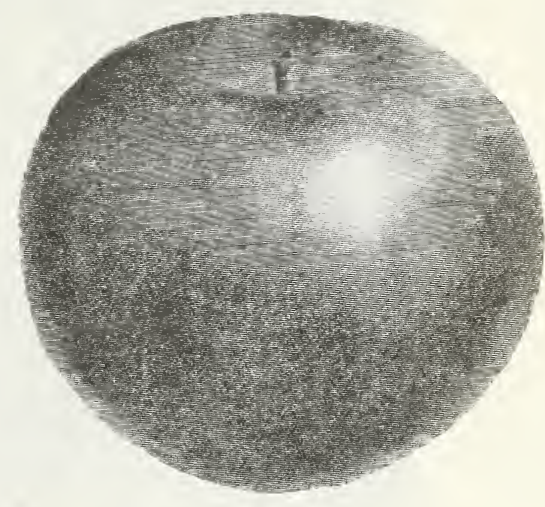

Grimes Golden

Grimes' Golden. Tree upright and hardy, fruit full, color golden yellow when ripe, medium to large, quality sub-acid, mild and melting; valuable in any orchard.

York Imperial. Medium, oblate; white, shaded with crimson; flesh firm, crisp, juicy and subacid. A good bearer and keeper; one of the best winter apples; moderate. November to April.

Stayman's Winesap. It is one of our best quality apples. Seedling of the old Winesap, but much better. Fruit nearly twice as large, much better quality, very fine grain, crisp, tender and juicy. It excels many others as a keeper. It is very hardy, a strong grower and very productive. A fast grower, foliage perfect, root system strong, will grow on poor land where the old
Winesap would die. This apple will make you money. Hangs till November; large to very large, somewhat cone-shaped, completely covered with dark red, indistinctly striped subacid.

N. W. Greening. A greenish yellow of large size. Very juicy and sub-acid. A good cooker and a splendid keeper. The tree is hardy and a very strong grower. It does not come into bearing very early but it pays well for itself after it does come into bearing. It is a reliable tree and the fruit finds ready sale.

MeIntosh Red. One of the best apples we have today. It is of the Fameuse class. Extremely attractive in appearance. Very large and very tender and has a delightful odor. Does extremely well in certain parts and certain sections of the northern states. The tree is a very stout grower, long lived, and a heavy bearer.

Gano. The fruit is bright red on yellow ground (no stripes); large; oblong, tapering to the eye; surface smooth, polished; dots minute; basin shallow, sometimes deep; eye large, cavity deep, brown in color; stem medium to long; core medium. Season January to April. Tree healthy vigorous, hardy; an early annual and prolific bearer. 


\section{APPLES-Continued}

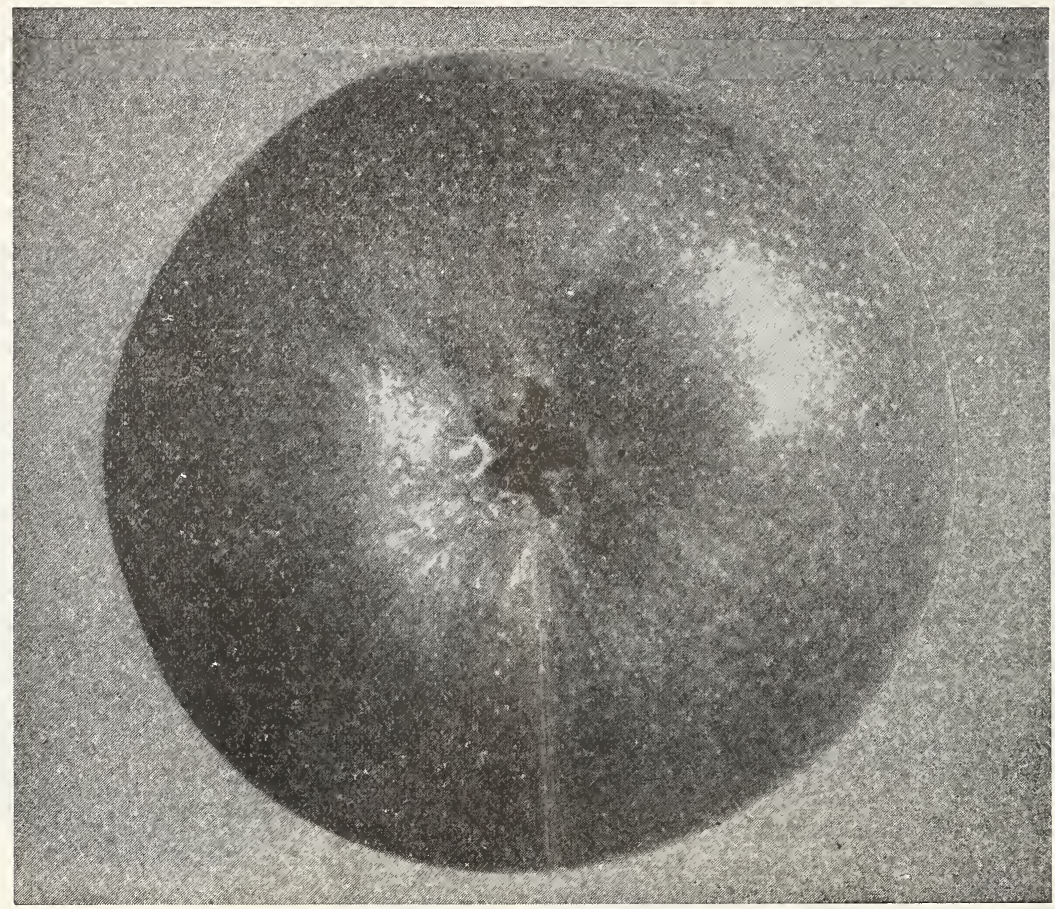

Vaughn's Seedless Apple.

\section{VAUGHN'S SEEDLESS APPLE}

This remarkable apple tree was found by one of our local agents in Vermillion county, Ind., and we have secured the sole right to propagate and sell it.

Now we do not claim that this is the largest apple known, for there are many varieties just as large, nor is it the best flavored apple, for there are others just as good, but there are none so sure to bear a crop each year, and few that will keep as well, and upon the strength of the above statements we recommend it to our customers.

Why is it that an apple tree will bear a heavy crop of fruit one year, and then bear few or no apples for one to three years afterward? You have all noticed this; you will say that the tree in producing and maturing the heavy crop of fruit robbed itself of so much vitality that it was not able to produce fruit the second or third year; that it had to have time to recuperate and grow new wood and fruit buds before it could produce again; this we will admit is the correct theory; but did you ever stop to consider what portion of the apple took the vitality from the tree? Is it the skin or flesh? No, for they are composed mostly of water and the tree can produce them as easily as it can leaves, without loss of strength.

It's the seed of the apple, and nothing else, that robs the tree of its strength and causes it to produce only two years out of five. In Vaughn's Seedless Apnle we have gotten rid of the element that produces barrenness, and by planting this variety we can raise apples every year.

Description-The fruit is about the size and shape of the Winesap; flesh firm and yellow, like the Russet, with a flavor similar to the Rambo; nearly red in color, with small yellow dots, and will keep until May.

The tree has no bloom for late frosts to destroy, but the fruit is set in the closed bud; the fruit has a large open calyx, which is an advantage over all other apples, for in spraying you can easily get the mixture with its poison into the calyx where it will be waiting for the pesky codling moth when it makes its appearance.

Each

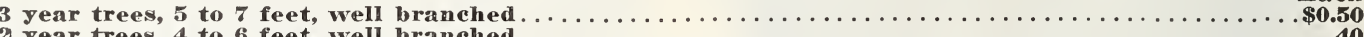

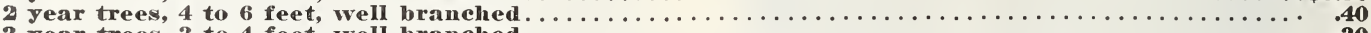

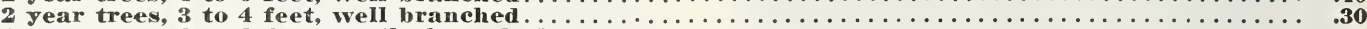

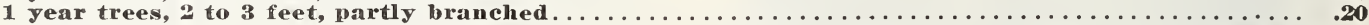

Fairbury Nurseries,

Maryland, Neb.

Fairbury, Neb.

Dear Sirs:- Received the trees in the best condition and am well pleased with the careful attention you have given my order, and your trees are fine. My neighbors from seven to ten miles ¿way came down on horseback to see them and all thought them dandies. I will try to get more customers for you. Whenever we need somethins else in your line of business we will surely send customers for you. Whenever we need somethins else in your line of business we will surely sen
jur order to you. 


\section{Crab Apples}

The improvements in the varieties of Crab Apples have kept pace with the other kinds of fruit. A few years ago it was only thought fit for cider, jelly and preserves, but there are varieties now that command good prices in the market for dessert purposes; especially is this true of the Whitney. Besides being useful they are very ornamental when in bloom and when burdened with their load of highly colored fruit.

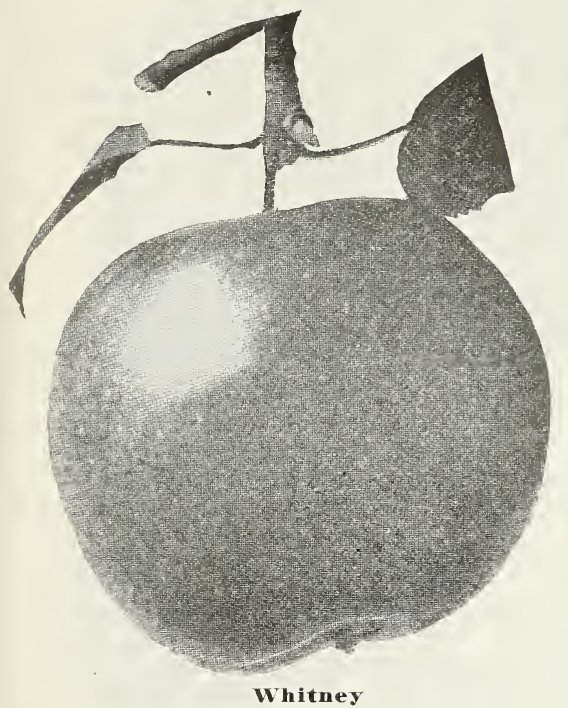

\begin{tabular}{|c|c|c|c|}
\hline & Per 1 & Per 10 & Per 100 \\
\hline 5 to 6 feet, 3 years, fine trees $\ldots .$. &.$\$ 0.22$ & $\$ 2.10$ & \\
\hline $\begin{array}{l}\text { to } 5 \text { feet, } 2 \text { years, wel } \\
\text { to } 4 \text { feet, } 2 \text { years, well }\end{array}$ & .16 & 1.50 & 14.00 \\
\hline to 3 feet, 2 years, partly branched & .10 & .90 & 8.00 \\
\hline
\end{tabular}

Hyslop. Medium size, crimson red with blue bloom. Fine quality, very showy. Should not be planted north of here. September to October.

Whitney No. 20. A large crab, $1 \frac{1 / 2}{2}$ to 2 inches in diameter. Skin smooth, glossy green, striped with red. Flesh firm, juicy and flavor very pleasant. A fair dessert apple, and one of the best for cider and vinegar. Tree a great bearer and very hardy. Really deserves a place in our apple list. There are few early varieties of so much merit. One of the best for Northern states. Ripens in August.

Transcendent. Fruit medium, brownish red and handsome. Excellent for jelly and preserves. Good grower and immense bearer. September.

Golden Beauty. Very large and handsome; fine amber or golden yellow color.

\section{Pears}

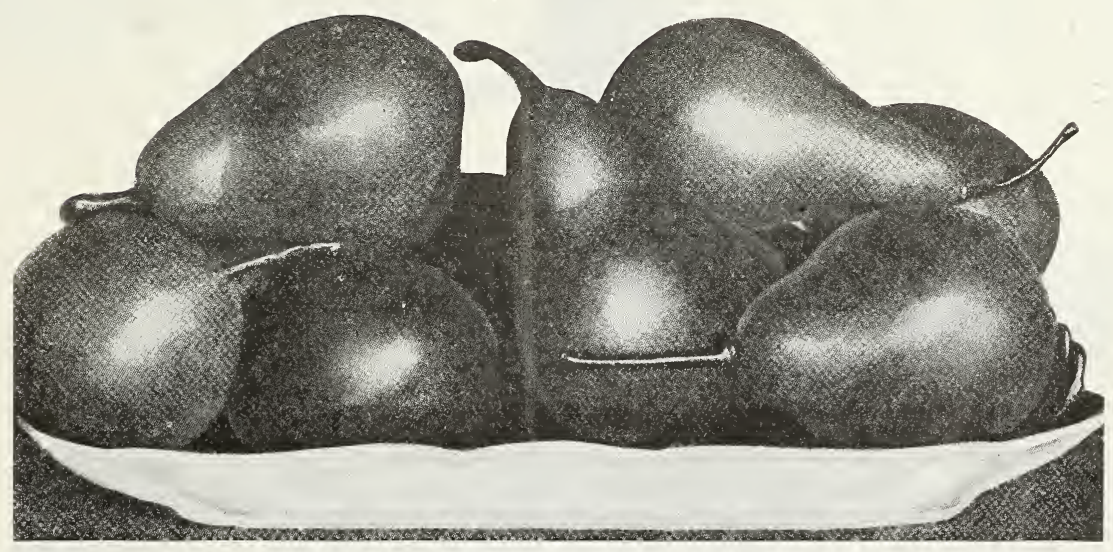

Dish of Clapp's Favorite Pears

The Pear tree will grow in almost any good soil, but thrives best in a heavy clay or loam. Standards are best for permanent orchards, dwarfs for fruit gardens or small lots. Dwarfs must be planted deep enough to cover the junction of pear and quince two or three inches and should have about half of the previous season's growth cut off each spring. Their side branches should not be removed higher than a foot from the ground. Given rich, well-tilled soil and pyramidal training. they are very productive and usually begin to bear the second season after planting. Our dwarf trees are budded on the best French quince stocks.

Two very important points in Pear culture are often neglected; the proper thinning and the gathering of the fruit. When the trees are heavily laden the fruit should be thinned when about gathering of the fruit. Will be poor and the trees injured. Summer Pears should be gathered about ten days before they are ripe; autumn Pears at least a fortnight; winter varieties, if they will hang so long, may be left until the leaves begin to fall. If, on gently lifting the fruit, the stem separates readily from the twig, it is ripe for gathering. Winter Pears may be stored in any dry cellar and kept until early summer; other varieties may be ripened on shelves in any cool, airy place. 


\section{PEARS - Continued}

Dwarf Pears come into bearing two years after transplanting and Standards not until the eighth year.

\begin{tabular}{|c|c|c|c|}
\hline & er 1 & Per 10 & Per 100 \\
\hline 5 to 7 feet, Standard, 3 years, extra fine. & .32 & $\$ 3.00$ & $\$ 28.00$ \\
\hline to 6 feet, Standard, 2 & .25 & 2.25 & 20.00 \\
\hline to 4 feet, Standard, 2 years, branched $\ldots \ldots \ldots \ldots$ & .20 & 1.75 & 15.00 \\
\hline o 4 feet, Dwarf, 2 years $\ldots \ldots$ & .20 & 1.80 & 15.00 \\
\hline to 3 feet, Dwarf, 2 years & .18 & 1.40 & 12.00 \\
\hline
\end{tabular}

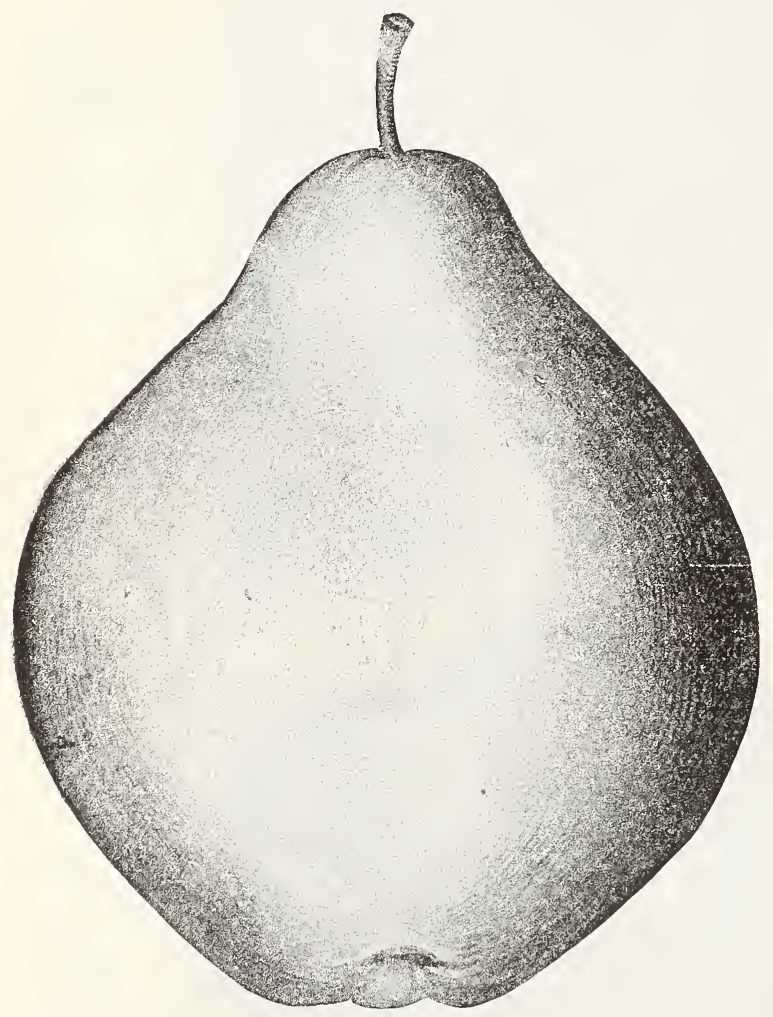

Duchess d'Angouleme.

Bartlett. Large size with often a beautiful blush to the sun; buttery, very juicy and highly flavored; bears early and abundantly; very popular. August.

Clapp's Favorite. Very large, yellowish green to full yellow when ripe, marbled with dull red in the sun and covered with small russet specks, vinous, melting and rich; season, July.

Kieffer's Hybrid. The pear was raised from seed from Chinese Sand Pear, accidentally crossed with the Bartlett or some other kind grown near it. Tree has large dark, green glossy leaves, and is of itself very ornamental is an early and very prolific bearer. The fruit is of good quality, wonderfully showy and is valuable for the table and market. It never rots at the core, and is as nearly blight proof as is possible for any pear to be. September and October.
Duchess d'Angouleme. Very large, dull greenish yellow streaked and spotted with russet, flesh white, buttery and very juicy, with rich and very excellent flavor, of the quince, to which stock this variety seems well adapted. It is always fine, the large and fine appearance of this fruit makes it a great favorite. September and October.

Seckel. Small, skin rich yellowish brown when ripe, with a dull brownish red cheek, flesh very fine grained, sweet, is exceedingly juicy, melting, buttery, the richest, highest flavored pear known. August and September.

Flemish Beauty. Is large, beautiful, juicy, melting, rich and fine, good bearer, is hardy everywhere. August and September. 


\section{Nectarine Trees}

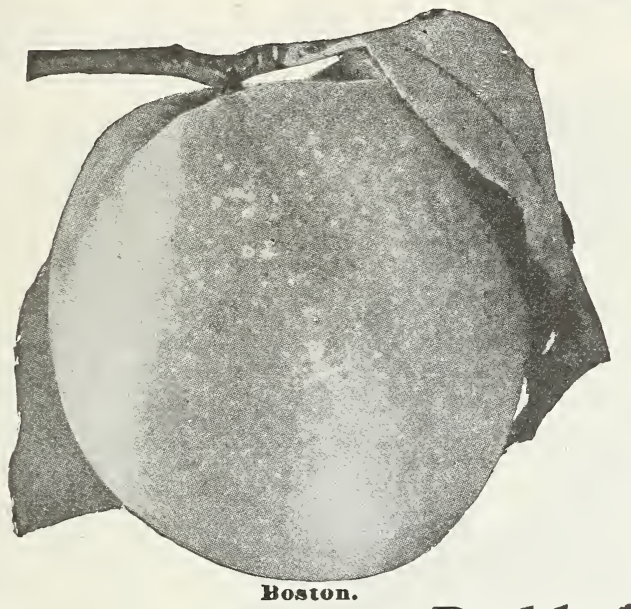

Budded Peaches

The peach tree requires a moderately rich, well drained soil, and in order to preserve the con. tinued healthy growth of the tree and thus cause it to produce well matured fruit, its branches should be headed in each year.

Pe set twenty feet apart, or they may be planted between apple trees. Plant them deep enough so that the crook in the tree where they were budded is covered over with earth.

In Nebraska we cannot expect a full crop of peaches each year, owing to our cold winters, which kill the bloom buds; but if you can only get a full crop once in three years they will pay you better than any other crop that can be raised in Nebraska, cherries and strawberries excepted.

Below we give a short description of those varieties which we consider among the best, the greater number of which we have fruited in our own grounds.

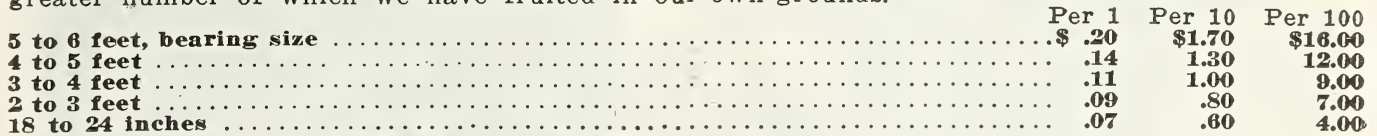

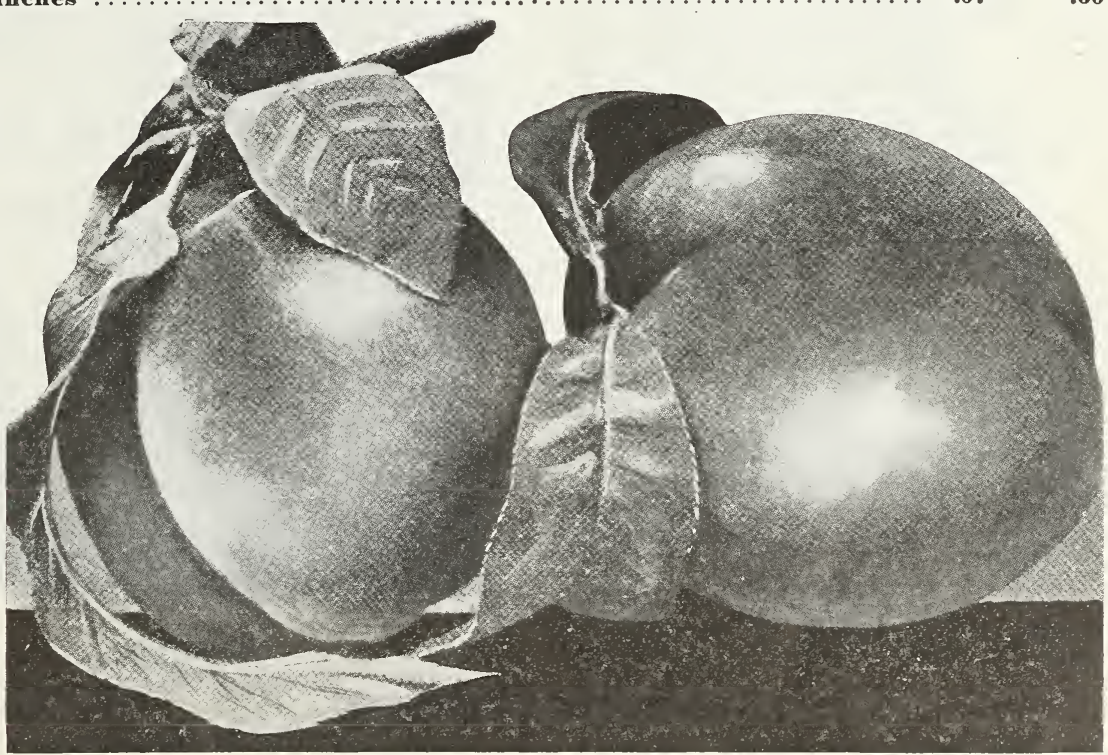

Champion Peaches

Champion. Many specimens have measured 10 inches in circumference. The flavor is delicious, rich, sweet and juicy; surpasses all other early varieties; skin creamy white with red cheek, strikingly hnadsome. It is hardy, productive, the largest size, highest flavor and best shipper of the early peaches. Ripens in early August. 


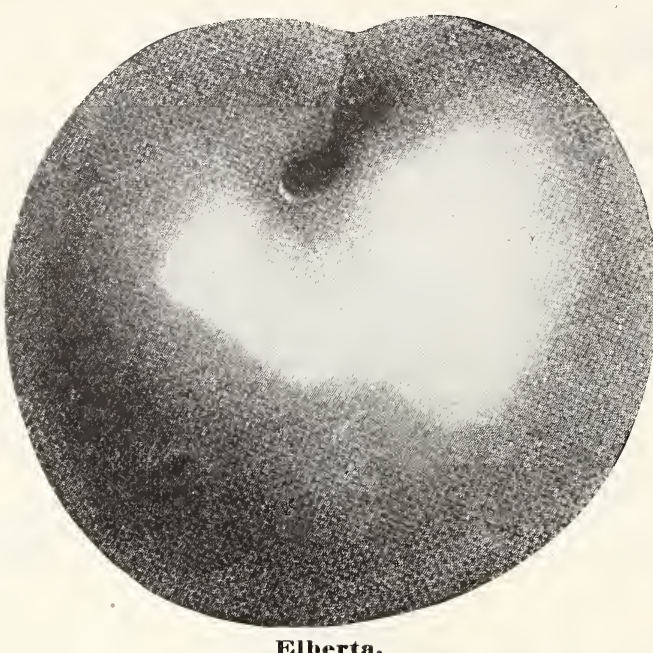

Elberta.

Alexander Early. Large size, well grown specimens, measuring eight inches in circumference, handsome and regular in form with deep maroon shade, covered with the richest tint of crimson, rich and good in quality, with a vinous flavor; adheres to the stone; should remain on the tree until fully ripe. Late in June.

Crawford's. Early. This beautiful yellow peach is highly esteemed for market purposes. Fruit very large, oblong; skin yellow with fine red cheeks; flesh yellow, juicy, sweet, excellent, productive, free. Last of July.

Crawford's Late. Fruit of the largest size: skin yellow with dull red cheek, flesh yellow. productive, one of the best. Last of August and September

Elberta. A Georgia cross between Crawford and Chinese Cling; very large, well colored; all things considered, the finest yellow freestone in cultivation; no one can go amiss by planting it; fruit perfectly free from rot, and one of the most successful shipping varieties. August 20.

Bokara No. 3. Freestone. Was first raised from seed from Bokara, Asia, by the Iowa Agricultural College. It is the hardiest peach I know. Has been in bearing for a number of years in Iowa, and it is claimed the fruit buds will survive 22 degrees below zero. Fruit is large, red with yellow cheek, skin tough, flesh of good quality. Prof. Budd says: "They are 30 per cent hardier than any of the old varieties." Ripens 1st to 10th of September. I can recommend this peach to all my customers in Nebraska, Iowa, Kansas and northern Illinois. You will not be disappointed.

Triumph. Earliest yellow flesh peach, with good eating and shipping qualities. Ripens with Alexander, blooms late, sure and abundant bearer; strong, vigorous grower. Fruit good size, yellow with red and crimson cheek. Fruit growers have given the strongest testimonials to its value.

Mountain Rose. Large, red, flesh white, rich, juicy, excellent; one of the best early peaches, ripening with Troth's Early, and much larger and finer than that variety; should be in every collection. July.

Croshy. Medium size; bright orange yellow, streaked with carmine. On account of its beautiful color and fine quality, it commands a ready sale in competition with the best standard market sorts. Claimed to be the hardiest of all peaches. Good for home and market; free. September 10

Salway. Late peach, fruit large, roundish yellow, with rich marbled brownish-red cheek; flesh yellow, firm, juicy, rich, sugary. Showy market peach; is very promising; finest in the world for canning. October. Free.

blood Cling. Large size, dark claret, with veins downy; flesh deep red, very juicy, fine flavor; tree an irregular grower. October.

Chinese Cling. Most popular Southern peach, immense size, oblong, creamy skin with faint blush of red. August.

The Mayfower Peach. Clingstone. The Mayflower is the earliest peach in the market. A week earlier than Alexander or sneed. It is of good size and fine color, being absolutely red all over, even before it is ripe enough to ship, thus making a very handsome, attractive peach. The earliness and rich color of the Mayflower makes it so valuable for the market. In quality it is fully as good as Sneed or Alexander. The tree is a strong and thrifty grower, has large blossoms that come out after all other peaches have bloomed. Thus the tree often escapes late frost and bears well, while the fruits of other varieties are killed. It is a young bearer, often bringing a few fruits the first year after transplanting. It is apt to set too much fruit and should be thinned out to secure the best results. The fruit keeps well for an early peach.

Price of the Ma:Aower: By Freight or Express $2-3$ feet, budded .......\$0.14 $\$ 1.20 \quad \$ 11.00$ -4 feet, budded, partly

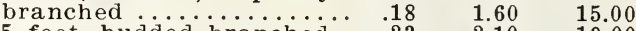
4-5 feet, budded branched . $.23 \quad 2.10 \quad 19.00$

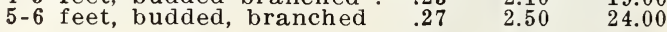

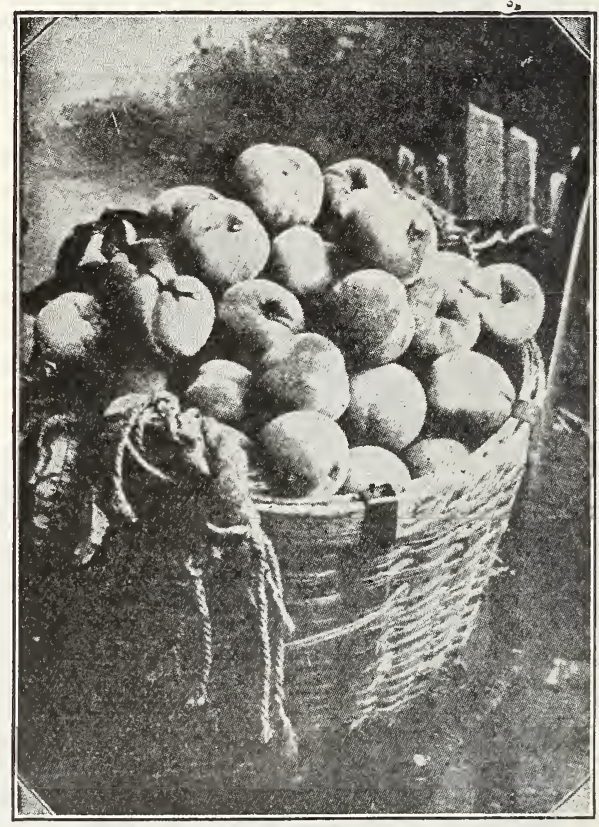

Mayflower.

\section{Seedling Peaches}

Our seedling peaches are grown from seed taken from freestone fruit and the trees will produce fruit of good quality. We have no names for them.

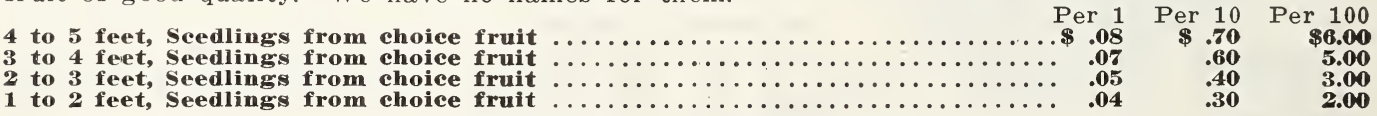




\section{Plums}

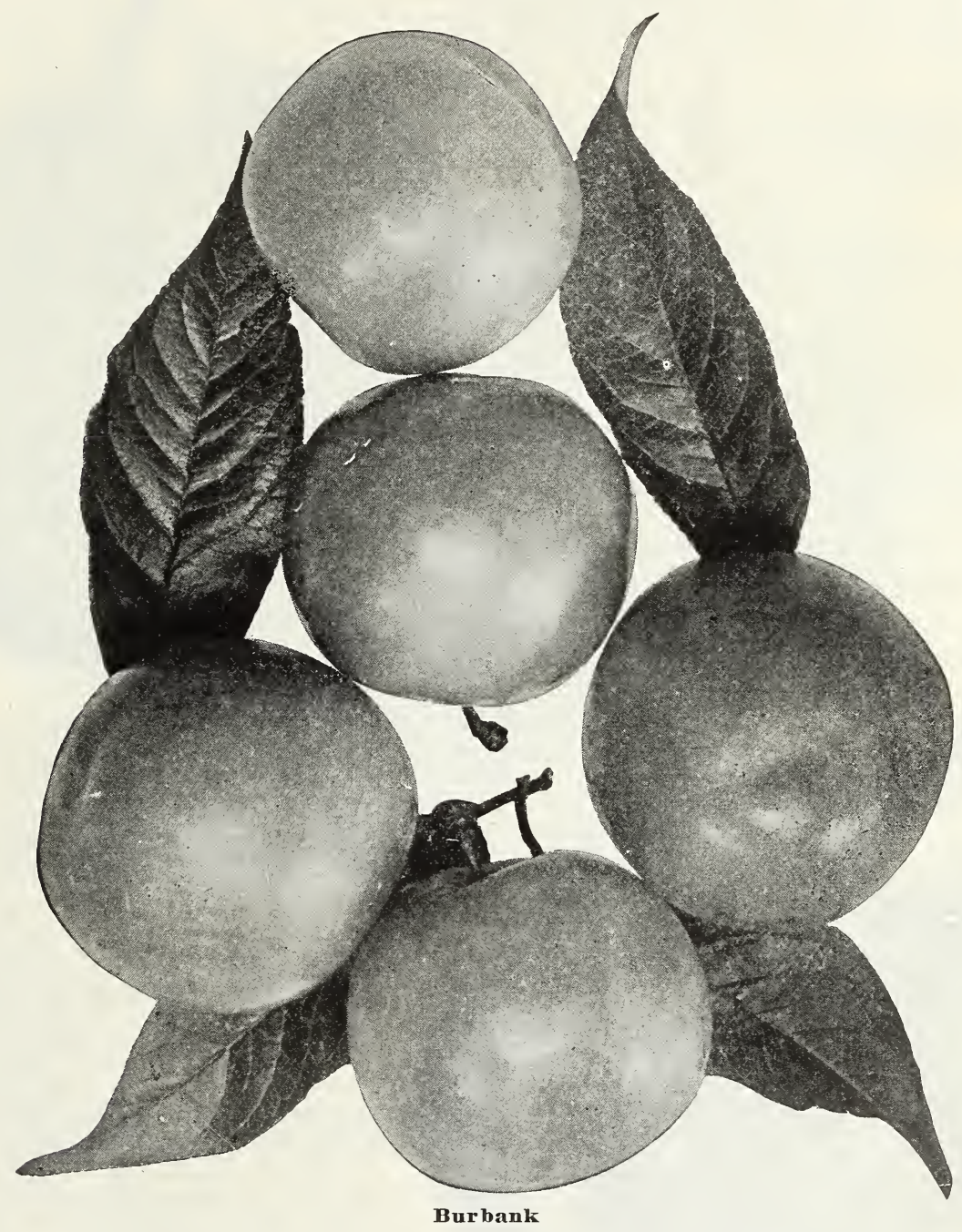

The plum does best on a rich, well drained soil. The trees should be planted sixteen feet apart, and it is well to plant several varieties together, for they seem to produce larger crops in that way than where a single variety is planted alone. Prune them so they will be low headed, and thus protect the fruit from wind storms which sometimes play sad havoc with the fruit when commencing to ripen.

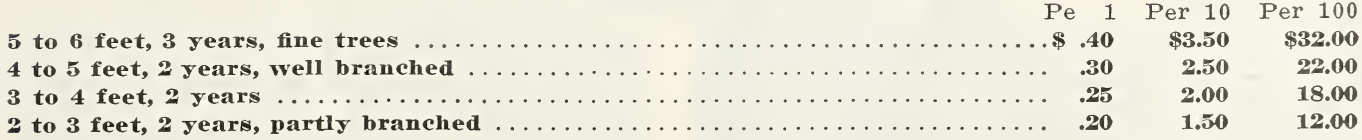

Abundance. Of medium size, large when thinned, amber with markings of red, juicy, sweet, of good quality when well ripened. May be picked when it begins to color, will keep a long time, color well and be almost as rich and sweet as if ripened on the tree-a strong point for market growers. Usually the fruit must be thinned to prevent overbearing. August. 
Burbank. The best of all the Japan sorts of plums, nearly globular, clear cherry red, and with a thin lilac bloom. The flesh is deep yellow color, very sweet, with a peculiar and very agreeable flavor, free vigorous with strong, upright shoots, large, broad leaves, commences to bear usually at two years. It blooms late and consequently more liable to escape the late spring frosts.

Woll. Fruit nearly as large as Lombard, and a perfect free stone; quality superb for cooking and for serving with sugar; tree a good grower, hardy and is becoming very popular wherever known, promising to lead all other native plums. August.

Lombard. Medium, round, oval, violet red, juicy, pleasant and good, adheres to the stone, productive. A valuable market variety, one of the most hardy and popular. Last of August.

Wild Goose. Large, rich, crimson, beautiful flesh, soft, rich, melting, delicious, with a full fruit flavor; tree a strong grower, prolific. This variety is among plums what the Ben Davis is among apples-referring to the American class of plums. July.

German Prune. A large long, oval variety, much esteemed for drying, color dark purple, of very agreeable flavor. September.

Prof. Hansen's New Hybrid Plums.

Prices on Opata, Sapa and Hanska Plums:

$\begin{array}{rrrrrrr}2 & \text { to } 3 \text { feet one year } \ldots \ldots \ldots & .30 & \$ 2.50 & \$ 20.00 \\ 3 \text { to } 4 \text { feet two year } \ldots \ldots & .40 & 3.50 & 30.00 \\ 4 \text { to } 5 \text { feet two year } \ldots \ldots & .50 & 4.50 & 40.00\end{array}$

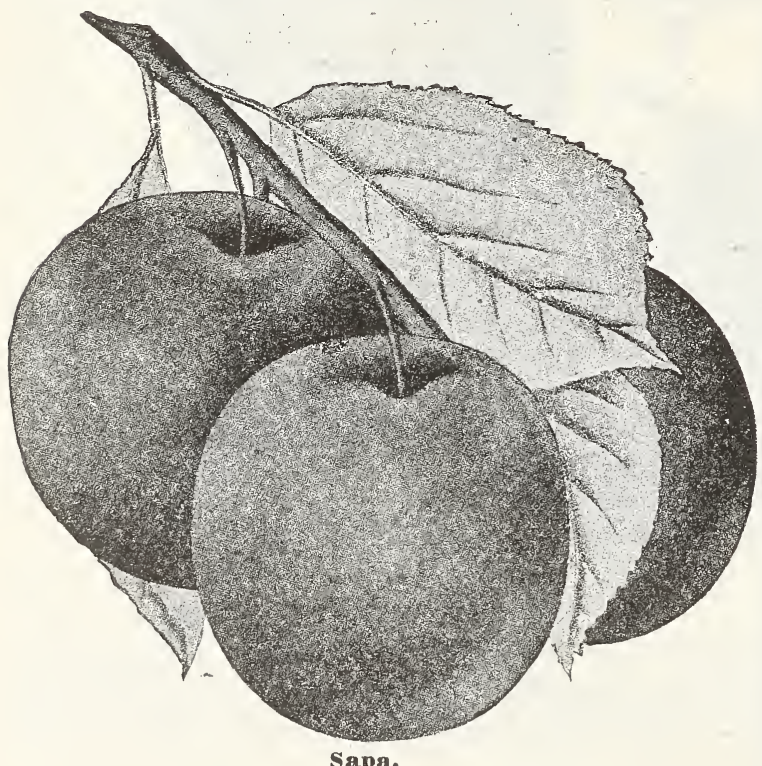

Sapa.

\section{Hanska}

Hanska. (Sioux Indian for TALL), and refers to the extraordinary growth and symmetrical shape of the Hanska plum. The Hanska does not come into bearing as early as those varieties containing Sand Cherry blood, but three and four-year-old trees in the nursery were loaded with most excellent fruit. The Hanska was produced by crossing a wild Northwestern plum with the very large, firm fleshed fragrant apricot plum of China-Prunus Simoni-which is so very popular in all of the orchards of California.

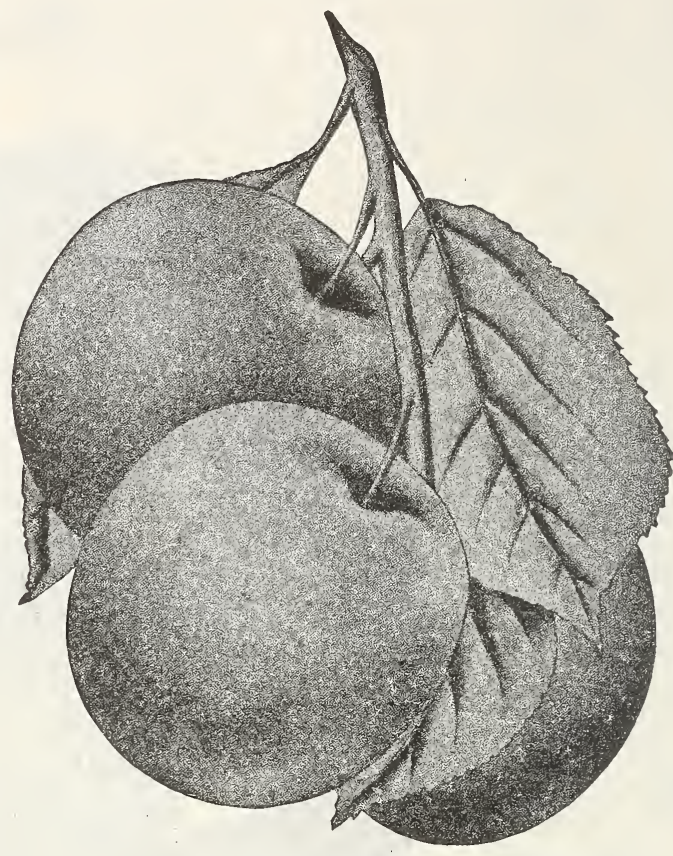

Opata.

Sapa. Very fine, perfectly hardy new plum. Prof. Hansen's description: "The female parent is one of our selected seedlings of the western sand cherry (Prunus Besseyi), favorite fruit of the Sioux Indians. The male parent, a large, purplefleshed Japanese plum originated by Luther Burbank, and by him named the Sultan. Sultan is of the Satsuma type and is perhaps a cross with some other species. The Sapa fruited first in 1907 on a tree cut back very severely for bud sticks. The tree is plum-like in habit; one-year trees in nursery have many fruit buds; the glossy, dark purple skin, and the rich dark purple red flesh of its Japanese sire. Sapa is Sioux Indian for BLACK. "As dark as the shades of evening ranked in the western heavens." Turning the branches of this tree back and exposing the long ropes of glossy black fruit to the rays of the sun, the background of the brown smooth bark and glossy dark green foliage, is certainly a pleasant sight and one to be remembered. This fruit is eatable and hangs on the tree for more than three weeks. When it first commences to mature, the skin is dark green and the flesh of the royal purple. The color of the skin and flesh gradually changes until it is as black as the darkest midnight. The skin of this variety is especially tender and practically disappears with ordinary canning. This plum makes excellent preserves and jelly and of the finest quality for eating fresh from the tree.

For Parcel Post prices see page 61 .

This variety has all of the good qualities a plum should have. The Hanska is a very large plum, a great many specimens measuring better than $11 / 2$ inches in diameter. Is of the best quality for eating from the tree, for canning, preserving, or making jelly. None of the California or native American plums compare with it in any way. In color it is a bright red with heavy blue bloom. In shape it resembles its male parent, the Apricot plum.

For cut of Hanska see second page of cover. 


\section{Cherries}

4 great deal of attention is now given to the growth of cherries in the West, and no well planted home orchard is complete without its proportion of cherry trees, and it is one of the most prolific of garden fruits. It will succeed in any kind of soil that is not wet.

It may be planted near the street, or used to line avenues as an ornament, and it will at the same time produce an abundance of delicious fruit. This may be eaten out of hand, preserved, or it will find a ready market at highly profitable prices, for shipping, canning, etc.

Our cherry trees are budded on Mahaleb cherry stocks, which do not sprout from the roots Care must be taken in planting that the trees are not planted too deep; one inch deeper than where budded is deep enough; should they be planted deeper than this, the tree will be liable to throw out roots above where budded, and these roots if broken will throw up sprouts or suckers.

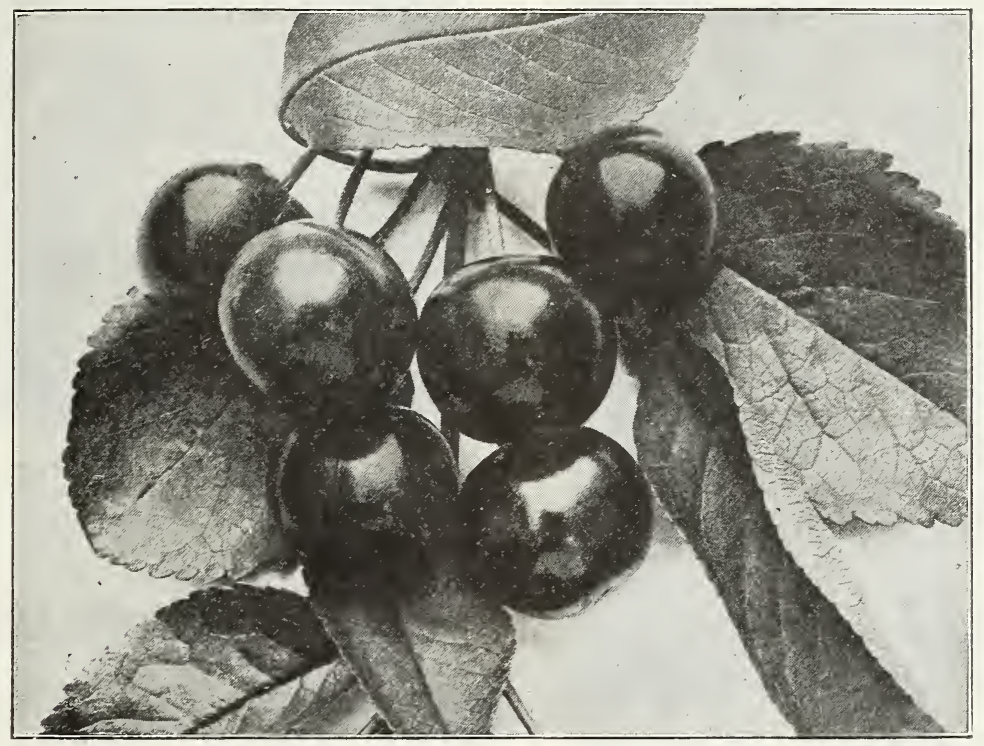

Montmorency.

Plant trees twenty feet apart, keep the main leaders headed back the first two or three years after transplanting. By so doing you will have flne bushy tops near the ground, which will be of great advantage in picking the frult.

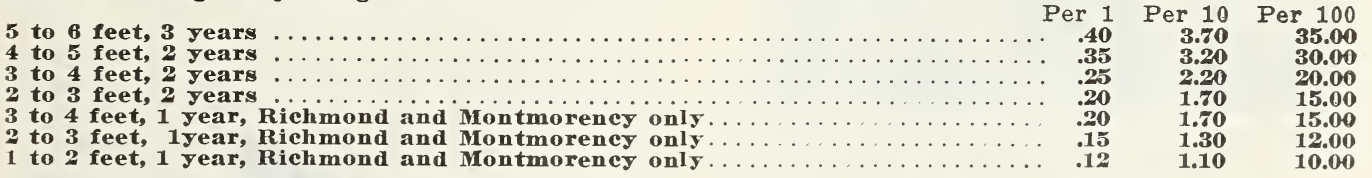

English Murillo. Tree slow grower, but very abundant bearer; very hardy; fruit slightly conical, dark red, almost black when fully ripe. Three weeks later than Richmond; most prolific. ostheim. A hardy cherry from Russia. It has been tested in the severest.winters of Minnesota, and has been found perfectly hardy. Fruit roundish, large, ovate; skin red, dark at maturity; stems long; flesh liver color; tender, juicy, almost sweet.

Early Richmond. The oldest and most reliable cherry tree grown today. It has proven its excellence for generations for home and local consumption. There is nothing to take its place. It is of good size. Light red in color. Very juicy and acid flavor. It ripens about the first of June. It bears very heavy and will produce a crop oftener than any other variety known. When in doubt, plant the Early Richmond, as it does best in all climates or on any soil.

Large Montmorency. The best of the Montmorency family and equal in value only by the Early Richmond. The Montmorency has all the good quality of the Early Richmond, but ripens tood quality of the Early Richmond, but ripens two weeks later. The fruit is identical with the Montmorency out under a great many different names, but there is only one Large Montmorency and we have the true strain.

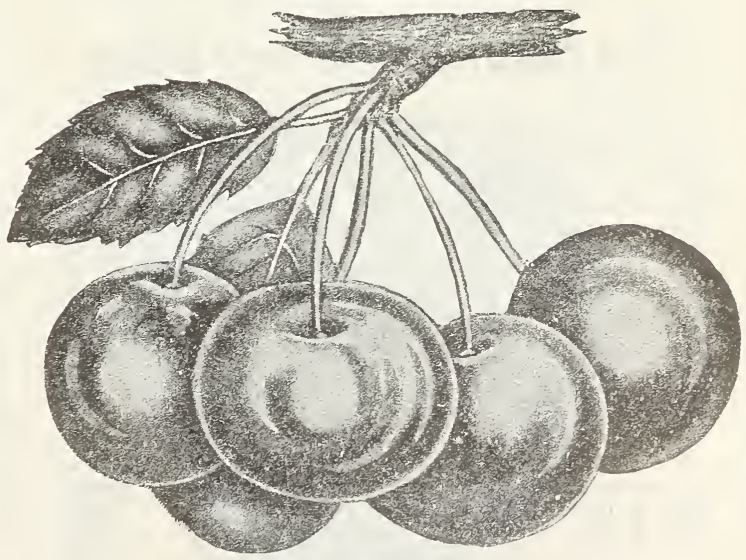

Early Richmond. 
Black Tartarian. June. The largest and one of the best. Fruit purplish black, with juicy, pleasant, tender flesh. The tree is strong-growing and produces immense crops every year, the fruit growing in huge clusters, making it easy to pick.

Grovernor wood. Large, yellow, shaded with light red, juicy, very delicious. A vigorous grower and very productive. Early Sweet.

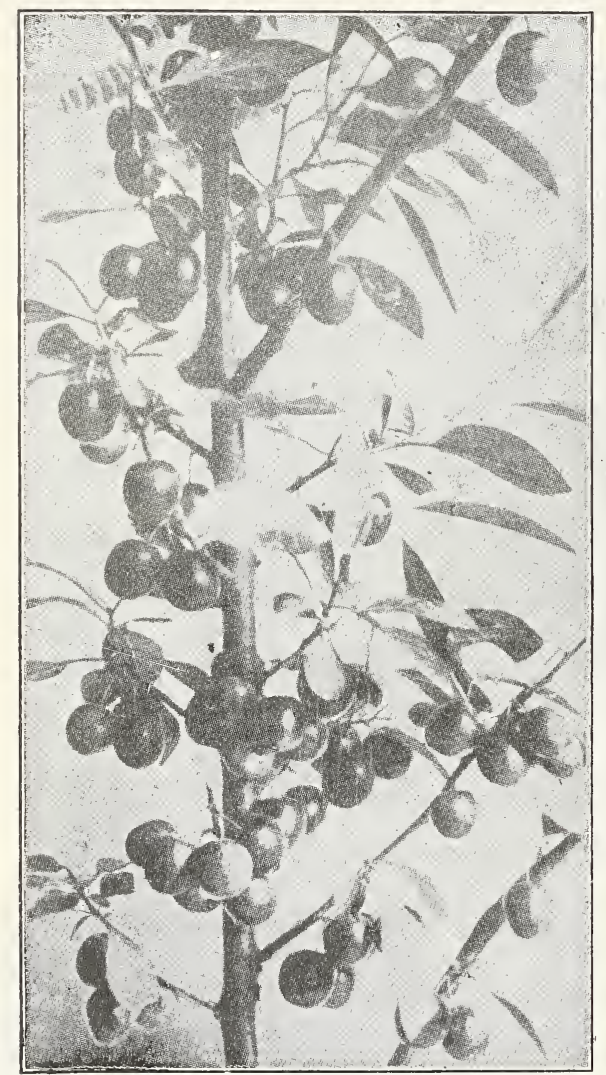

The Compass Cherry Plum.

\section{The Compass Cherry Plum}

The Compass Cherry-Plum originated with H. Knudson of Springfield, Minn., and is believed to be a cross between the Western Sand Cherry and the Miner Plum. Its habit of growth is like the Miner, while the leaf, twig and bark very much resemble the Sand Cherry. It is a strong grower, and makes a very fine orchard tree. Fruit about an inch in diameter, and is as much a plum as it is a cherry. The shape as much a plum as it is a cherry. The shape tween the ordinary American plum and Early Richmond pit in shape and size. It has a flavor peculiar to itself, very palatable and rich. An immense and early bearer. Tree perfectly hardy as far north as Manitoba.

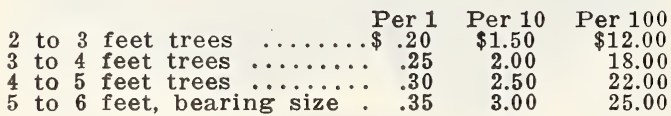

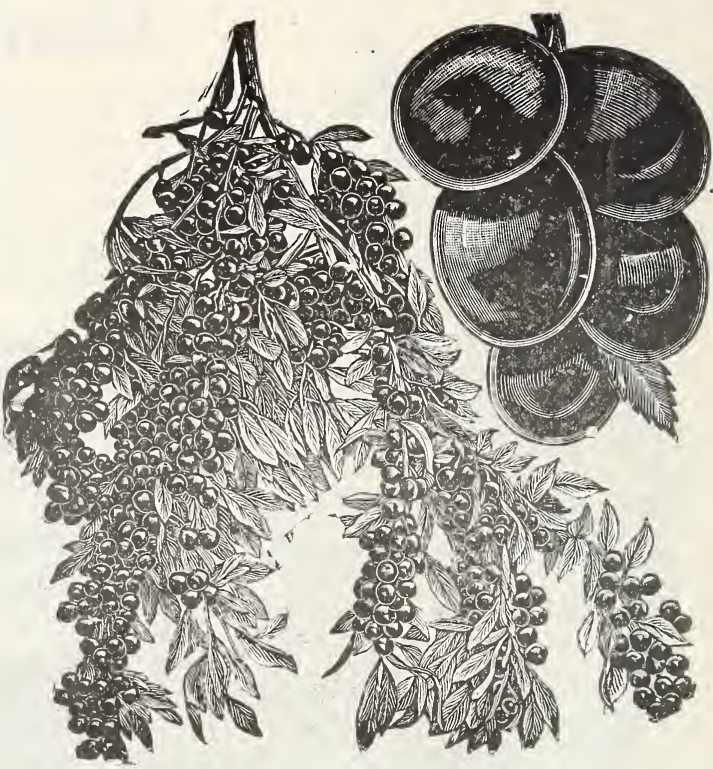

Rocky Mountain Cherry.

\section{Rocky Mountain Cherry}

This is a novelty and a very profuse bearer but the fruit is not as good as our leading sorts: grows in the form of a bush, and is as hardy as Wyoming sage brush. It has stood 45 degrees below zero and unharmed in limb or fruit bud; fruit about as large as English Murillo; cherry black when fully ripe; acid and very good for pie or wine. Season, July.

2 -foot trees, $15 \mathrm{c}$ each; 10 trees, $\$ 1.00$.

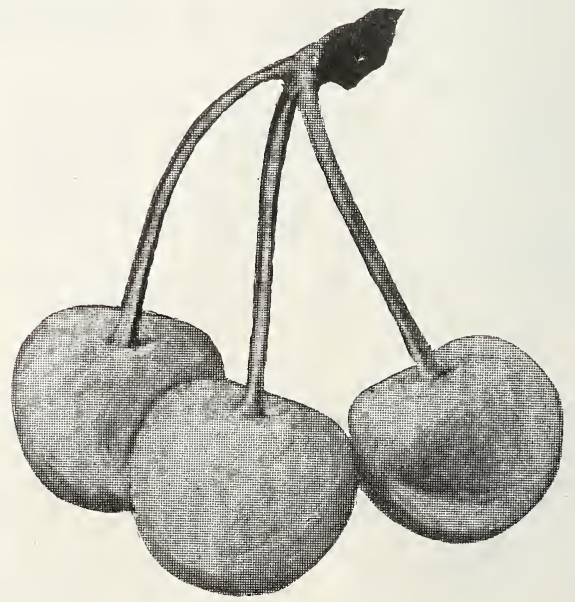

Gov. Wood. 


\section{Quinces}

Owing to the negligence of the cultivator, this valuable fruit is seldom seen in perfection, being mostly allowed to grow without the least attention or cultivation. The Quince requires a good, deep soil, which should be clean and mellow, with an occasional dressing of manure and sprinkling of salt; but does not need a severe pruning like many other varieties of fruit; a careful thinning out of the old decayed wood will be sufficient. Keep a vigilant search after the borer.

Apple or Orange. This popular old Quince is one of the most reliable varieties for market. Large to very large, roundish, with short neck; golden yellow flesh, firm and of fine flavor. October.

Bourgeat. A new kind, keeping well into midwinter. Very large, roundish, golden yellow; smooth and tender when cooked. Tree of re markably strong growth and very productive. October to February.

Champion. Noticeable for its early bearing and superb appearance. Very large, mostly oval; deep yellow; excellent quality. Tree very prolific and vigorous. A good keeper.

Meech's Prolific. One of the valuable newer varleties, bearing when quite young. Large roundish, pear-shaped; bright orange; fragrant and of excellent quality. Very productive.

3 to 4 feet, well branched Per 1 Per 10

$\begin{array}{rrr}3 & \text { to } 4 \text { feet, well branched } \ldots \ldots \ldots \ldots \$ 0.35 \\ 2 & \text { to } 3 \text { feet, partly branched } \ldots \ldots \ldots . .30 & \$ 3.00 \\ & & \end{array}$

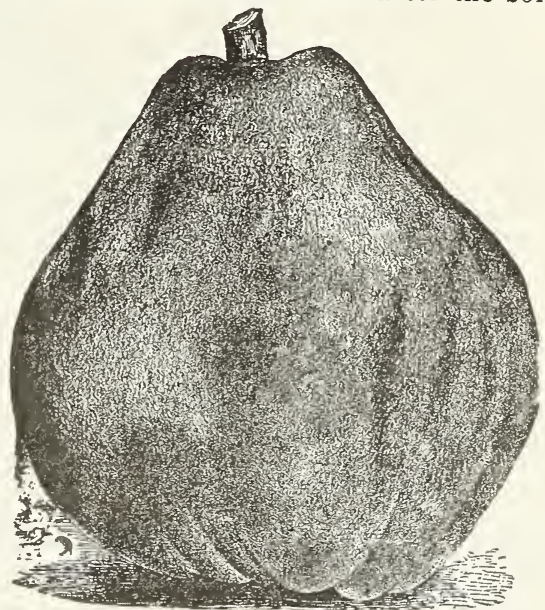

Champion.

\section{Apricot}

5 to 6 feet, 2 years, budded

- Per 1 Per 10

4 to 5 feet, 2 years, budded.

\$ .35

3 to 4 feet, 2 years, budded
2 to 3 feet, 1 year, budded

.20

Superb. One of the largest; orange with red cheek; firm, juicy with rich flavor; very pro-
ductive. August.

Royal. Large; yellow; with orange cheek Juicy, rich and delicious; a fine variety. Last of

Moorpark. One of the largest; orange with a red cheek; firm, juicy with a rich flavor; very productive. July.

Russian Apricot. A new variety of recent introduction; valuable on account of extreme hardiness of trees and fine quality of fruit.

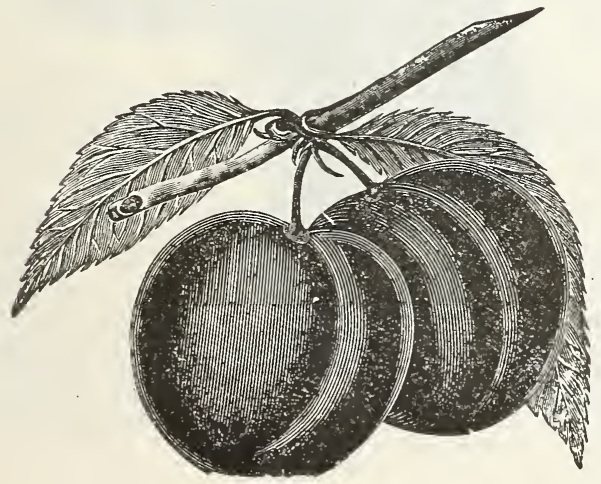

Kussian.

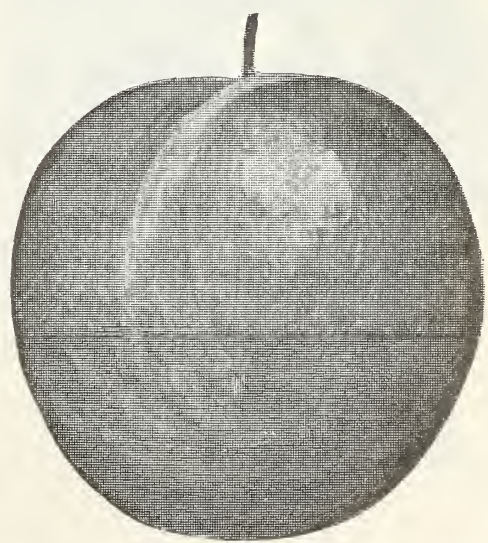

Moorpark. 


\section{Grapes}

The history of the grape is almost as old as that of man. Vineyards were extenisively planted before orchards or collections of other fruit trees were at all common, and today it is one of the most highly appreciated fruits. In its flavor it is hardly surpassed by any other fruit in delicacy and richness, and few or none are more beautiful in the dessert. Any person having a plot of ground ever so small, either in country or city, can find room for one-half to one dozen grape vines. They can be trained up the side of any building or over a garden fence; but the best and cheapest way to grow them in small or large quantities is on the wire trellis.

Work the ground deep and plant a little deeper than they were in the nursery. Make rows eight feet apart and six to eight feet in the row. Some of them, the tender varieties, would be benefitted by laying the vines flat on the ground during the winter, with a light covering of earth or litter.

Care should be taken to prune thoroughly each year, no more bearing canes should be left than the roots can sustain in a vigorous growth of new shoots. In a commercial way no fruit crop shows greater returns on the investment. On all markets grapes are very popular and command good prices. They should be planted more generally everywhere.

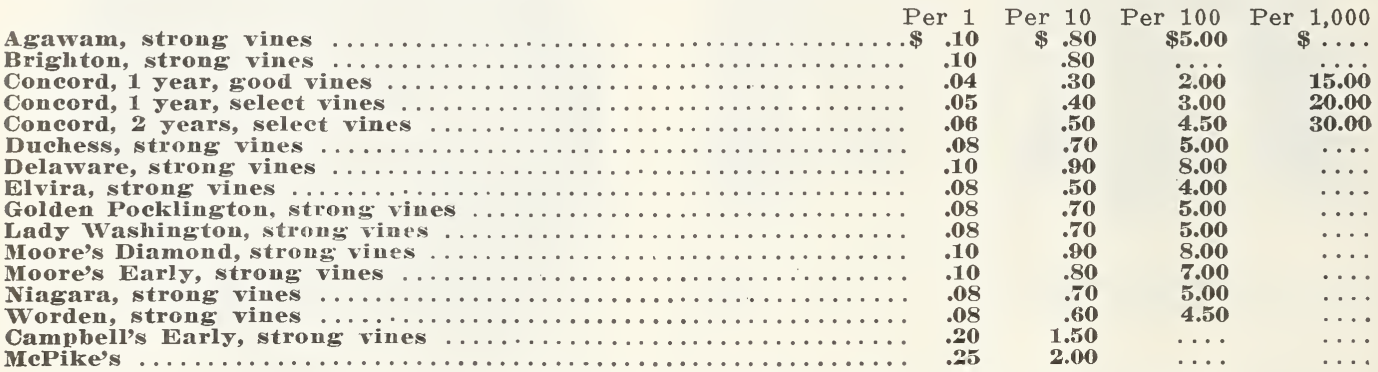

By Parcel Post prepaid add 2 cents for each vine ordered.

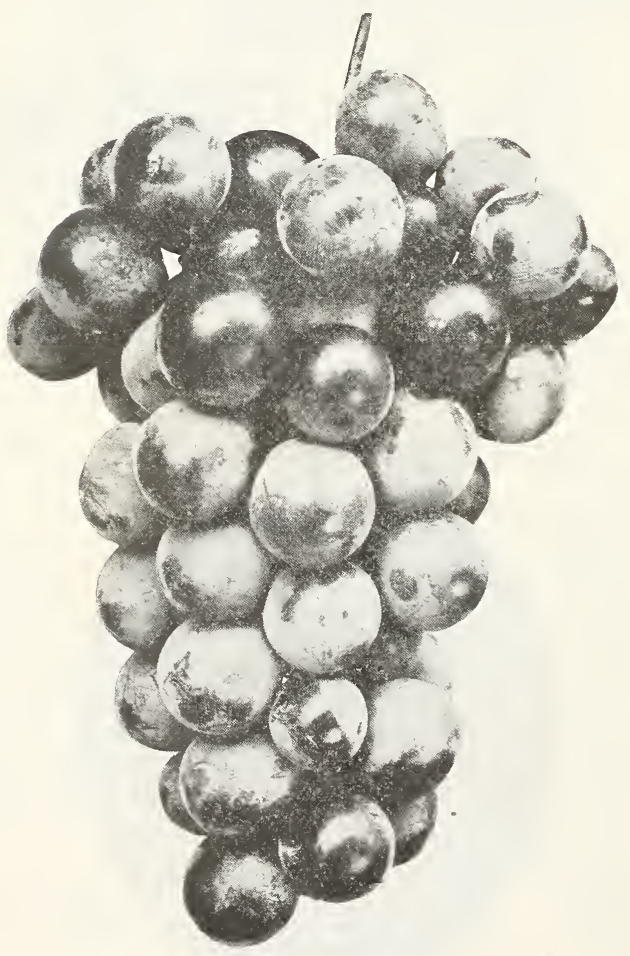

Moore's Early.

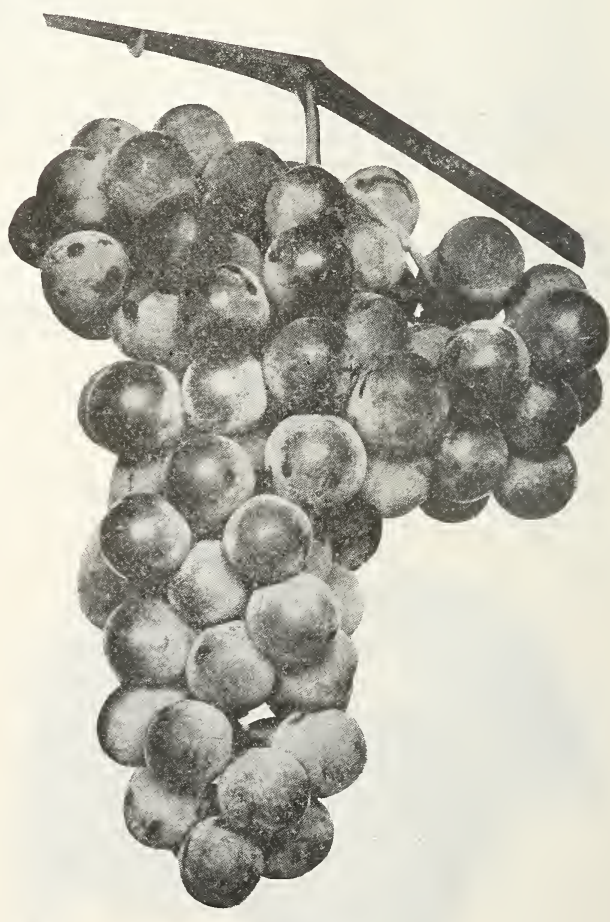

Niagara. 


\section{GRAPES-Continued}

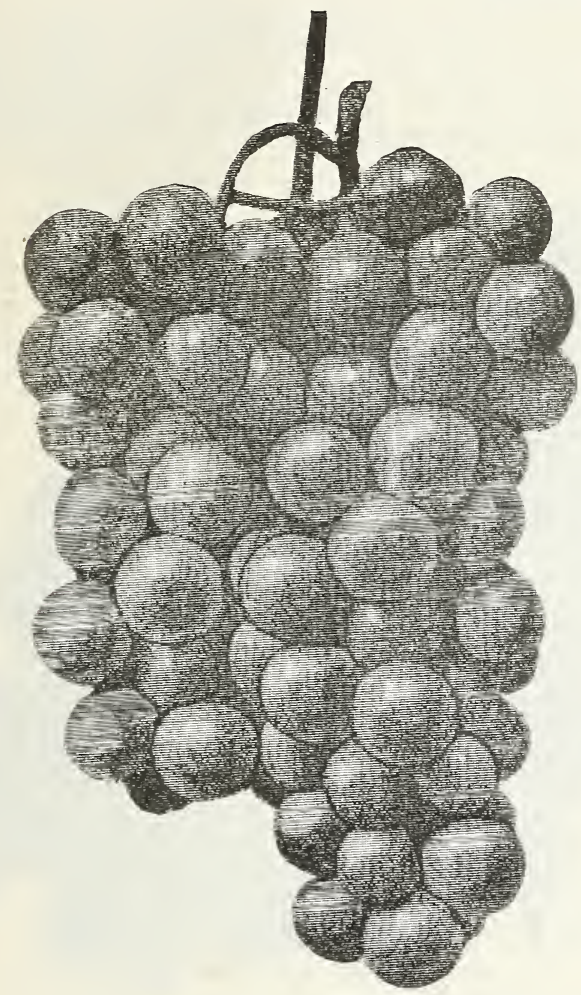

Campbell's Early.

Concord. Bunches large, berries large, round, skin thick and covered with bloom; flesh juicy, sweet. Very hardy, vigorous and productive, at present the most popular of all our native sorts.

Worden. This variety is a seedling of Concord which it greatly resembles in appearance and flavor, but the berries are larger, the fruit is better flavored and ripens several days earlier. Black.

Moore's Early. A large, black grape of the Concord type, the entire crop ripening before the Concord, bunch medium, berries large with blue bloom, flesh pulpy, of medium quality. Vine hardy, moderately productive, better as it attains age. Planted extensively as a market sort.

Agawam. Large, round, early and of great vigor of growth; rich, high, peculiar aromatic flavor, much subjected to disease and too highly flavored, where all its aroma is developed, to be desirable. Red.

Description of the MePike Grape. We have in this new, wonderful grape, great size, wonderfu quality, hardy wood and bud, very large leathery leaves. Fruit ripens same season as Worden, which is one week earlier than Concord. This grape ripens evenly, and only has one or two srape ripens evenly, and only has one or two has taken all premiums at all the great state fairs in the fall of 1898 and 1899 wherever exhibited, over all competitors. Many testimonials could be printed, if space would permit, regarding the success of this wonderful vine.
Campbell's Early. The king of grapes. The best all-around grape on the market. A very strong, hardy vine, with perfect, self-fertilizing blossoms, always setting its fruit well and bearing abundantly. Clusters very large, berries round and of great size, very sweet and rich. The seeds separate easily from the pulp; ripens first of August, but can be kept until December in cold storage; color black, with a light purple bloom.

Delaware. Still holds its own as one of the finest grapes; bunches small, compact, shouldered; berries rather small, round, thin skin, flesh very juicy; without any hard pulp; an exceedingly sweet, spicy, delicious flavor; vine moderately vigorous; hardy and productive. Red.

Brighton. A cross between the Concord and the Diana Hamburg; bunches large, berries of medium size; flesh sweet, tender and of the highest quality; ripens early. Red.

Moore's Diamond. Very hardy, healthy and vigorous; ripens from two to four weeks earlier than Concord. White.

Niagara. A magnificent white grape and very valuable for both garden and vineyard, a rank grower and very productive of beautiful bunches of the largest size; berries large, with tough skin; quality good; ripens with Concord.

Lady Washington. Fruit yellow, tinged with pink, bunches very large, often weighing a pound; vine strong, very healthy.

Golden Pocklington. Is a seedling from Concord; vine hardy, both in wood and foliage strong grower, called a white grape, but the fruit is a light golden yellow; clear, juicy and sweet to the center, with little or no pulp; bunches very large, sometimes shouldered; ber ries round, large and thickly set: quality, when fully ripe, much superior to Concord; ripens with Concord.

Elvira. Ripens about with the Catawba; a very strong, healthy and robust grower; productive; bunch and berry of medium size; very compact. White.

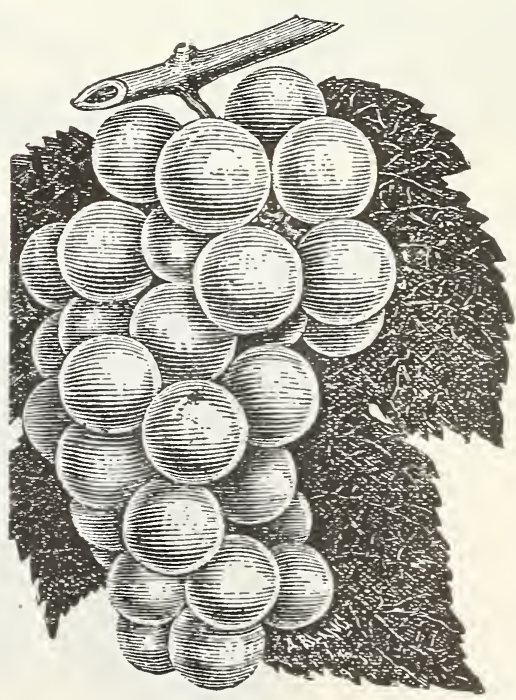

MePike. 


\section{Gooseberries}

Should be planted in good, rich soil, and well manured once a year. They will do well on any variety of soil if well drained and fertile. Prune regularly and thoroughly, cutting out all dead wood and all surplus branches. Do not let the bushes grow too thick; the fruit will be larger and more plentiful. Plant in rows four to six feet apart and four feet apart in the rows. Gooseberries should be planted in every garden, no matter how small; they are hardy, rugged and easily grown, and the fruit is sought for by every housewife for culinary purposes and sells well in all markets.

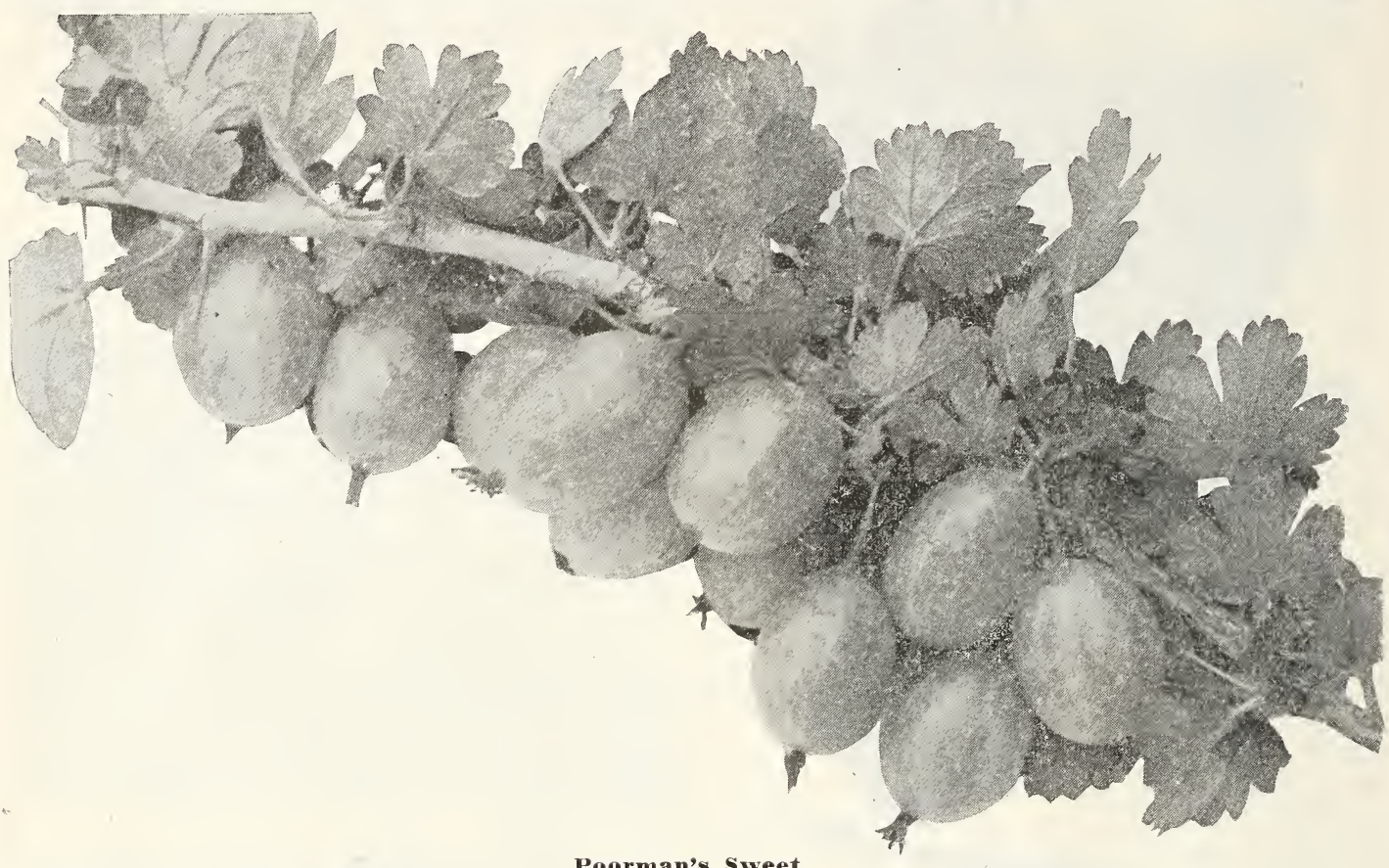

Poorman's Sweet

Per 1

Houghton, 2-year plants $\ldots \ldots \ldots \ldots \ldots \ldots \ldots \ldots \ldots \ldots \ldots$

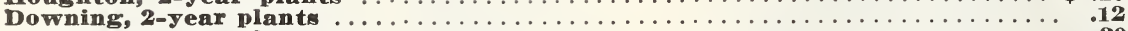

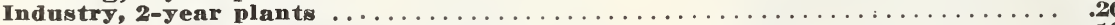

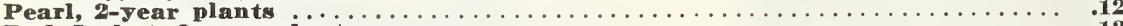

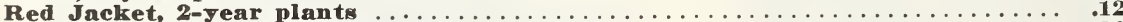

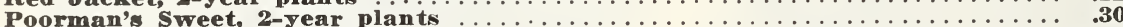

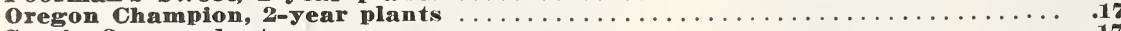

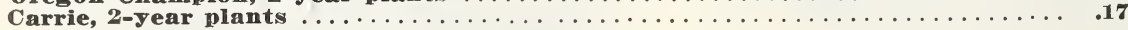

Per 10

$\$ .90$

1.10

1.80

1.10

1.10

2.50

1.50

1.50
Per 100 $\$ 8.00$ 10.00

16.00
10.00

10.00

20.00

12.00

12.00

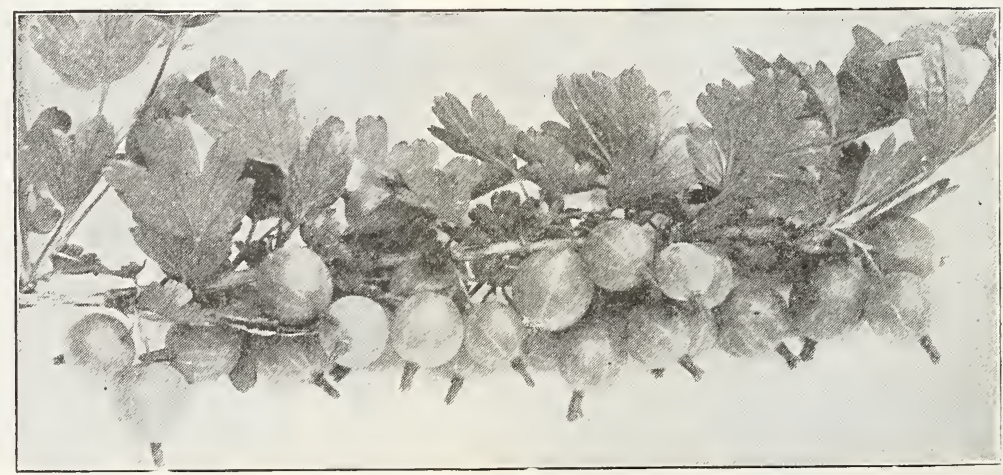

Oregon Champion 
Poorman's. It is so called from the fact that when ripe it is perfectly sweet, like a sweet cherry, and requires little, if any, sugar for culinary purposes. This most remarkable gooseberry is a seedling from Houghton and is as hardy as its parent. It is a very strong grower, the bushes being inclined to grow in tree shape. It is red when ripe, very large, and has a shape and flower like a plum.

Oregon Champion. Berries very large, brownish red color, very sweet and fine for table use and pies. Bush a strong grower, healthy and not very thorny and a very prolific bearer. I recommend this variety to my customers, especially for large plantations. It will bring good returns. Best berry for the market.

Houghton. An enormously productive and always reliable old variety. Of vigorous growth, slender and spreading, not subject to mildew. Fruit of medium size, smooth, pale red, tender and of good quality.

Carrie. A variety for Minnesota and claimed to possess "more valuable points of excellence than any other gooseberry," because "it is the most productive, the easiest picked, the most attractive, the most saleable, the most profitable, the hardiest, the healthiest, the freest from mildew, the earliest bearer." Fine for the North. Of a bright maroon color and of excellent quality. Most valuable gooseberry for jams, jellies and canning.

Downing. A well-known American sort, which has given the best results everywhere. Large and handsome, pale green berry; of splendid quality for dessert and cooking. Bush vigorous, a strong and upright grower and exceedingly productive. An excellent sort for family use and suitable for market. This variety is seldom affected by mildew.

Industry. The most planted in this country of any English sort, and is less subject to mildew. The bush is strong, upright and immensely productive. Berries are of largest size, dark red and of excellent quality, rich and agreeab?e. This variety should be pruned less than the other sorts, to secure the best results.

Pearl. A very desirable American variety. Very hardy, entirely free from mildew, superior

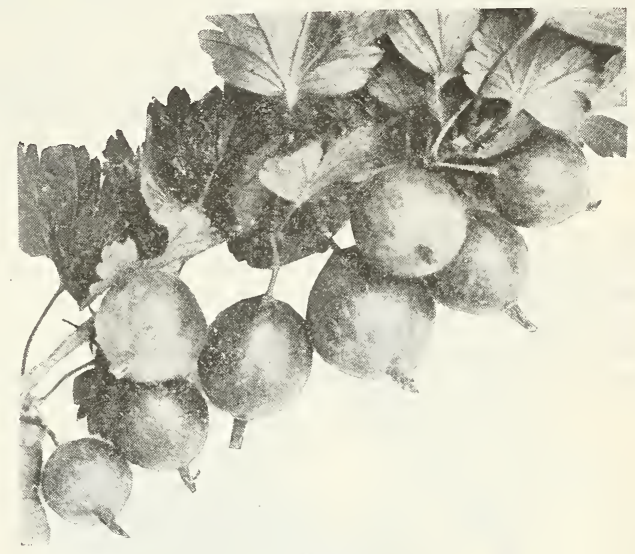

Carrie.

in size and quality, and more productive than Downing. We take pleasure in recommending It for small or extensive planting as one of the best berries of recent introduction. The large berries are pale green and of the finest quality, and valuable for home or market.

Red Jacket. (Josselyn.) This American seedling has been widely planted in recent years, and is highly recommended by all growers. Bush is very hardy; clean, healthy foliage and entirely free from mildew. Fruit large, smooth, pale red, and of first-class flavor and quality. It is considered the best fruited gooseberry in cultivation.

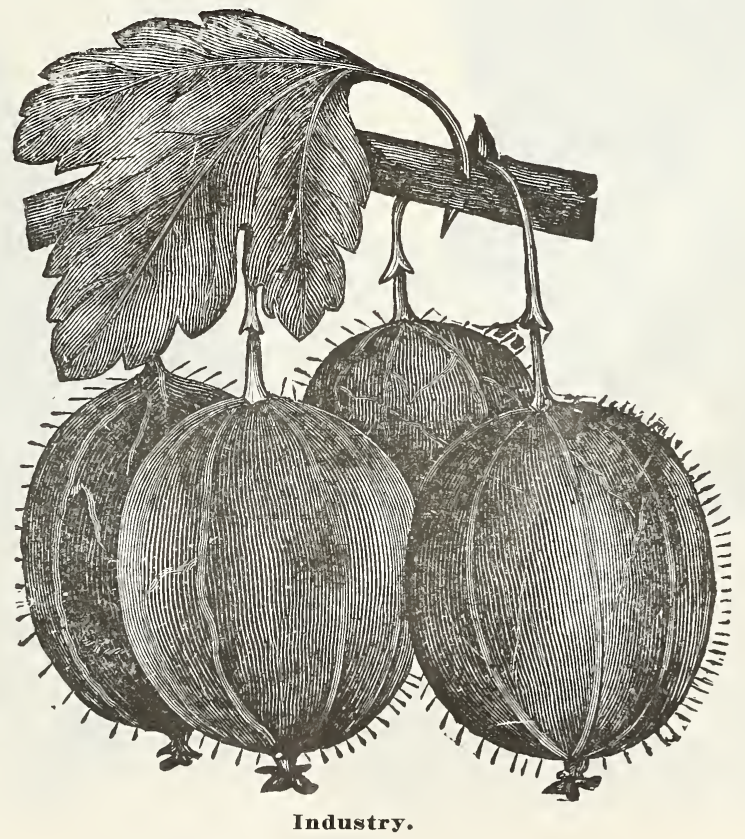




\section{Currants}

A cool, moist location is best for this fruit, and for this reason it succeeds admirably when planted by a stone wall or fence, being benefited by partial shade. Plant in rows four feet apart and the plants three feet apart in the rows. They should be pruned each year, and all dead wood cut from them. Keep them thinned out so that air can freely pass through them. Currant worms can be destroyed by the use of hellebore. Dissolve an ounce in three gallons of water, and apply with a syringe or small sprinkling can. This can be done with very little expense if performed at the right time.

Black Naples and Champion, 2 years $\ldots \ldots \ldots \ldots \ldots \ldots \ldots \ldots \ldots \ldots \ldots \ldots \ldots \ldots . \ldots \ldots$

Cherry, Red Dutch and Victoria, 2 years $\ldots \ldots \ldots \ldots \ldots \ldots \ldots \ldots \ldots \ldots \ldots \ldots \ldots . . \ldots 7$

White Dutch and White Grape, 2 years $\ldots \ldots \ldots \ldots \ldots \ldots \ldots \ldots \ldots \ldots \ldots \ldots \ldots . . .67$

Fay's Prolific and North $\mathbf{S t a r}, \mathbf{2}$ years $\ldots \ldots \ldots \ldots \ldots \ldots \ldots \ldots \ldots \ldots \ldots \ldots$.08

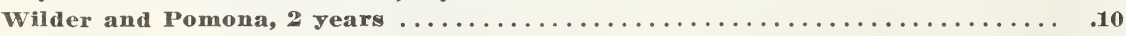

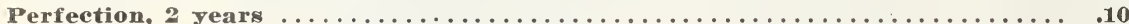

$\begin{array}{rrr}\text { Per } & 10 & \text { Per } 100 \\ \$ \mathbf{8 0} & \$ \ldots . \\ .60 & \mathbf{5 . 0 0} \\ .60 & \mathbf{5 . 0 0} \\ . \mathbf{7 0} & \mathbf{5 . 0 0} \\ .80 & \mathbf{6 . 0 0} \\ .80 & \mathbf{6 . 0 0}\end{array}$

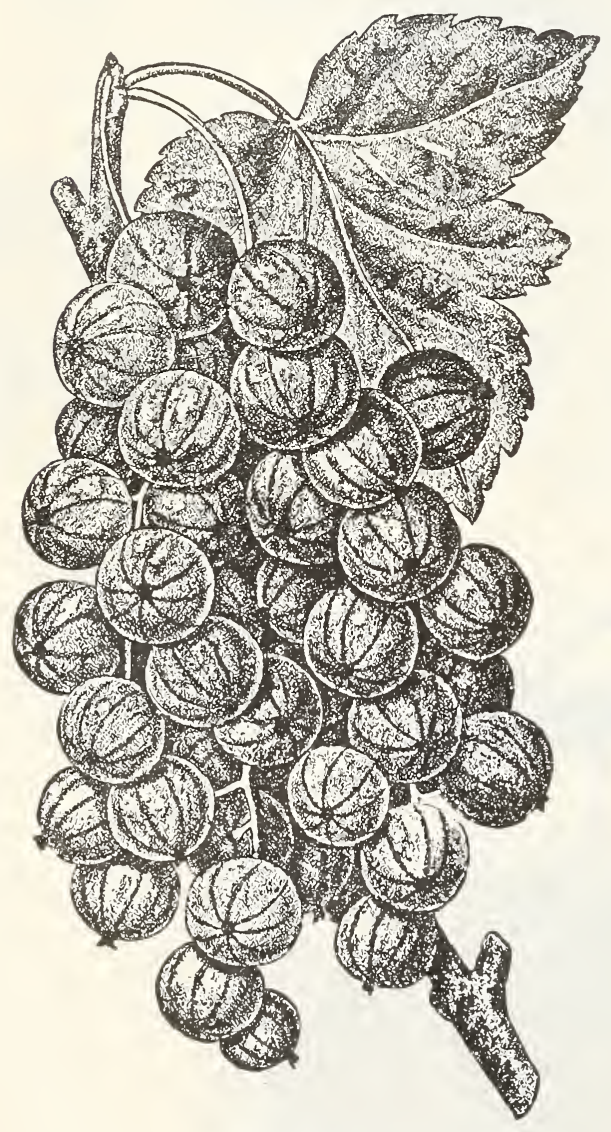

Perfection

Perfection. This grand new fruit was originated by Charles G. Hooker, of New York, Grape Currant, with the view of combining the large size and color of the Fay with the good quality and productiveness of the White Grape. The color is a bright red; size as large or larger than Fay, the clusters averaging longer. The Perfection has a long stem, making it easy to pick without crushing any of the berries. It is a great bearer. The berries are of rich, mild flavor, sub-acid, plenty of pulp, with few seeds. Less acid and of better quality than any other currant in cultivation. In my garden the Perfection is the best bearer, with largest berries; the sweetest currant I ever tasted, and the easiest to pick. Anybody can pick a basket of Perfections as fast or faster than cherries.

Fay's Prolific. Has fully sustained all the claims that were made for it by the originator when first introduced, and is the best red currant known. It has been widely planted and has given general satisfaction; fruit very large, bright red, and of excellent flavor, less acid than cherry. It has a long stem, which admits rapid picking, and is enormously productive. One of the most valuable fruits of recent introduction. Comes into bearing early. One of the best market sorts, and equally valuable for home use.

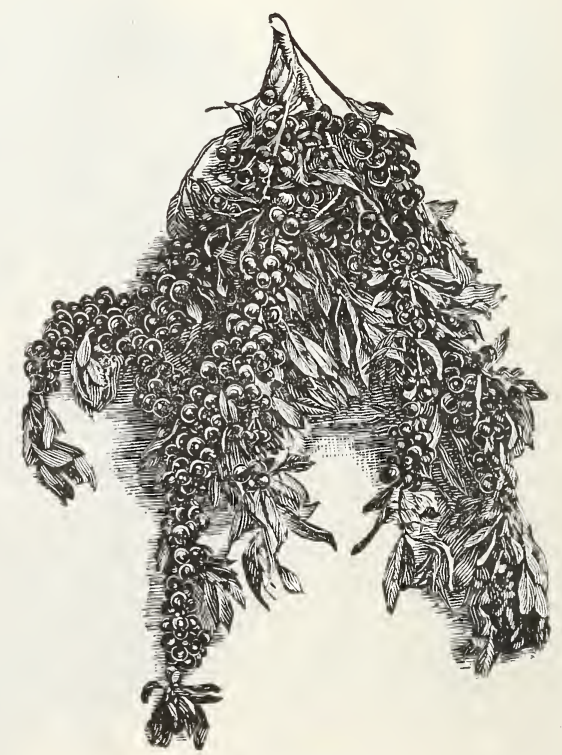

Fay's Prolific. 


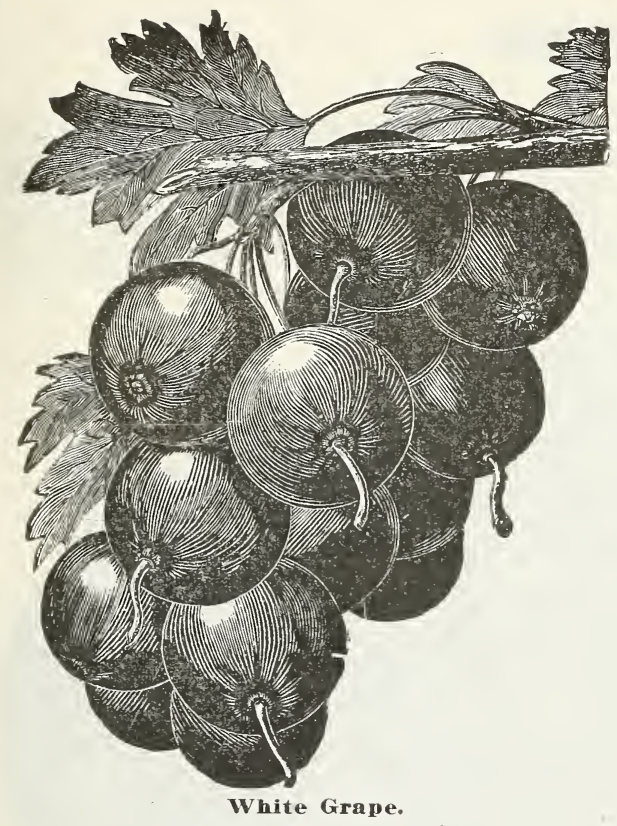

Pomona. (Knight's Improved.) Deserves prominence for its splendid market qualities. The fruit is of good size and flavor, bright red in color Has long stems and hangs in fine condition long after ripening. This variety first attracted notice for its enormous productiveness.

Wilder. One of the strongest growers and exceedingly productive. Clusters and berries very large; of attractive bright red color, even when dead ripe. Quality excellent, with mild sub-acid flavor. Ripens early and remains bright and firm until quite late Very profitable market sort. Bush grows upright and vigorous. Few varieties equal the Wilder in productiveness and vigor.

Black Champion. Very productive; large bunch and berry, excellent quality; strong grower. Leading black currant.
Cherry. Red. Bunches very large, sometimes measuring one-half inch in diameter. A strong grower and must have good cultivation to do well.

Victoria. Red. Bunches long; berries large, of a bright red color and excellent quality. A strong grower, extremely hardy. The best late variety.

White Grape. The best white currant. The bunches are large and full, berries large, sweet, of a beautiful translucent white and of mild, superior quality; very fine for table. Bush grows quite vigorous, somewhat spreading, and produces large crops. A dependable and very popular variety.

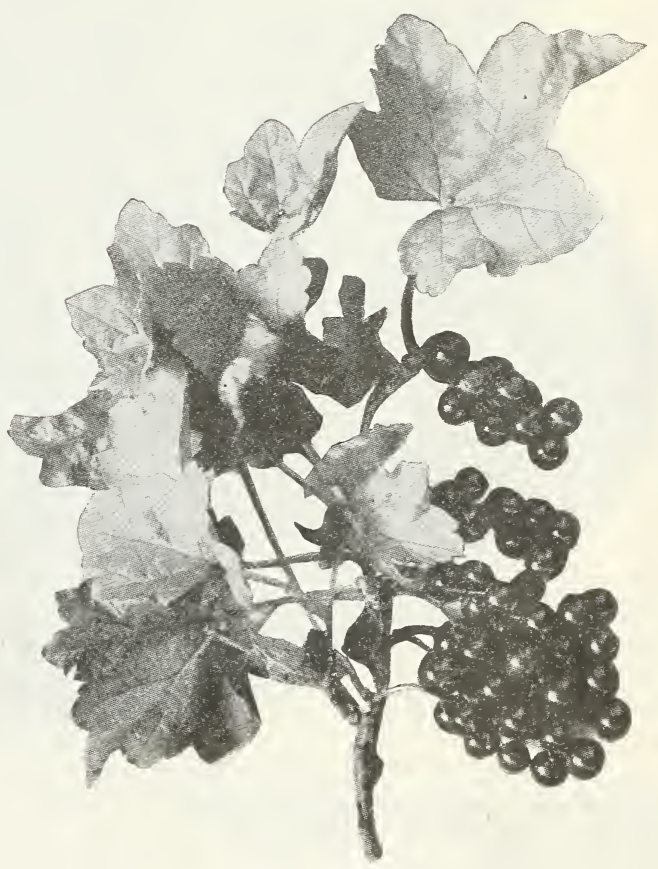

Black Naples.

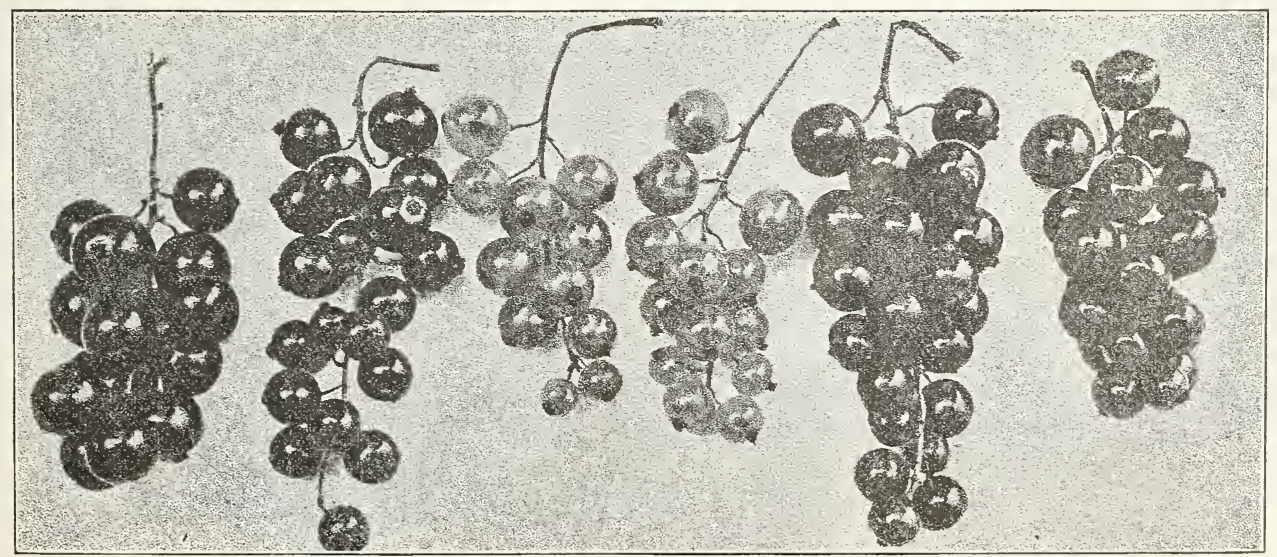




\section{Raspberries}

Raspberries should be set in the spring, plants three and a half feet apart in the row and rows four feet apart. Set plants three to four inches deep, depending on the soil (in heavy clay do not set as deep as on light soil), roots spread out and dirt pressed firmly among them. Give thorough shallow cultivation until the last of July, or if you prefer mulch in with coarse manure or something of that kind, and keep the ground well stirred between the rows. When the new canes are about two feet high, pinch off the top; this will make the plant throw out side branches and do away with the necessity of tieing up. In the spring cut these side branches back to sixteen or eighteen inches in length. Four or five good canes in a hill are enough. Cut out old canes as soon as through fruiting and burn them.

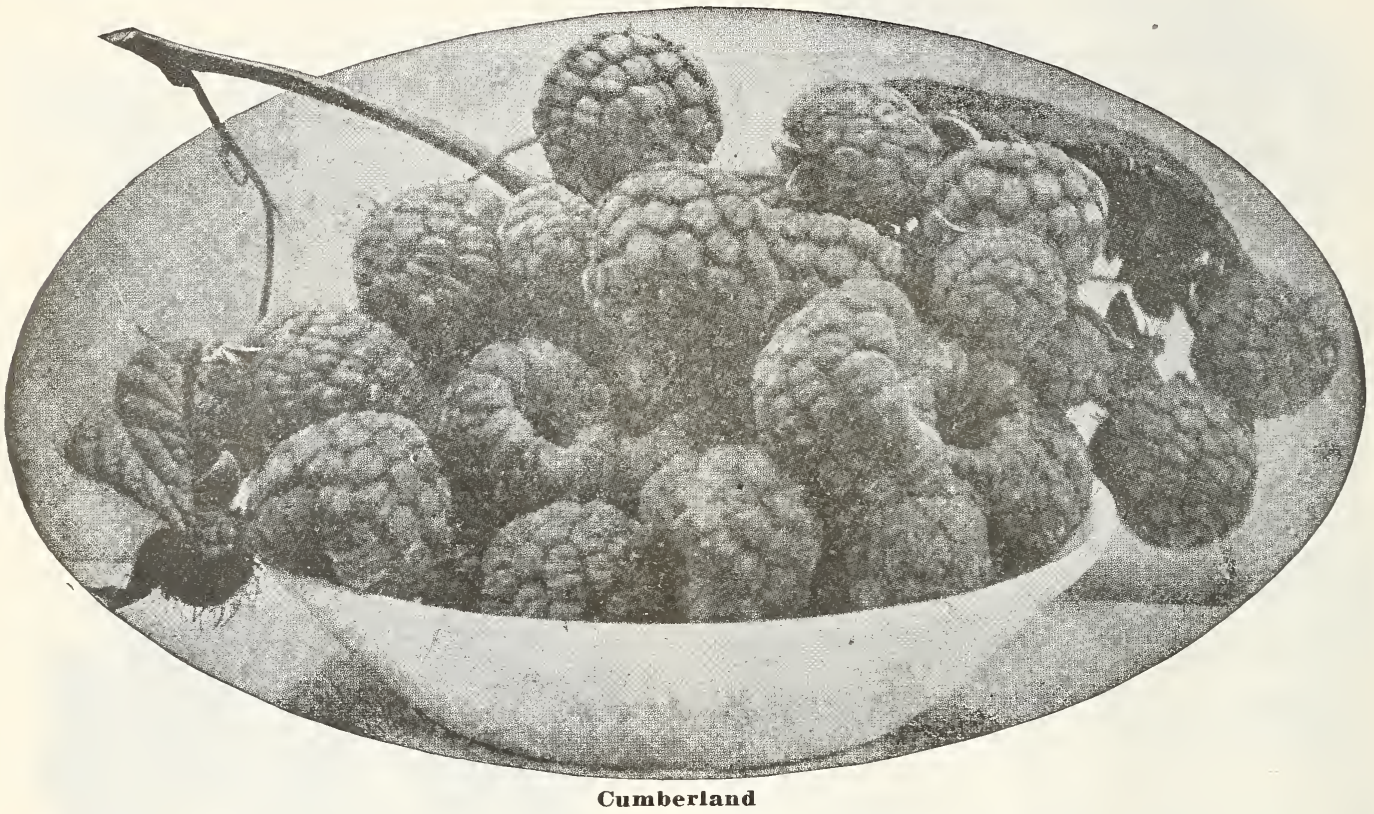

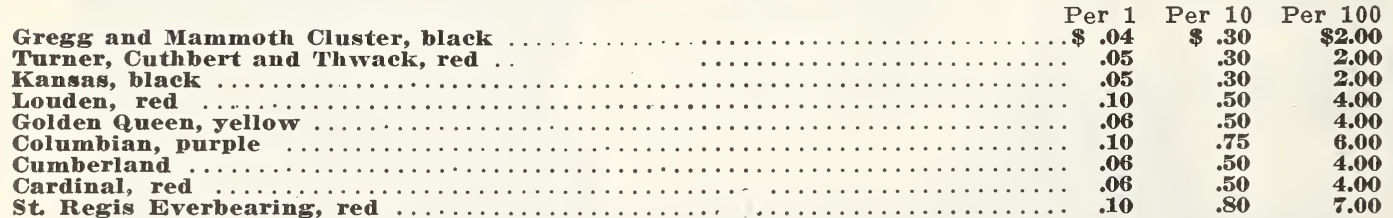

Grega. Leading Black Cap and a popular market sort; canes of strong, vigorous growth, and under good culture very productive; berries are large, covered with heavy bloom, firm, meaty and of fine flavor. It requires a good strong soil to produce best results; it is not entirely hardy, but suffers during unusually severe winters; it is by far the best Black Cap and the largest of any.

Mammoth Cluster. A well-known old variety, yet retained for its high quality and productiveness; rich and juicy, with much bloom; canes strong and vigorous; medium to late.

Kansas, Originated at Lawrence, Kan. It is healthy, vigorous and not subject to leaf blights; produces strong, healthy tips; fruit large, as fine a berry as Gregg and equally as good a shipper; ripens just after the Souhegan; very prolific.

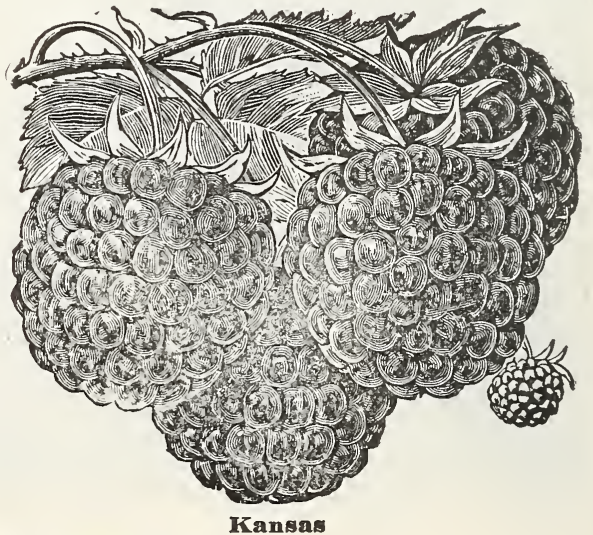

Kansas 


\section{RASPBERRIES-Continued}

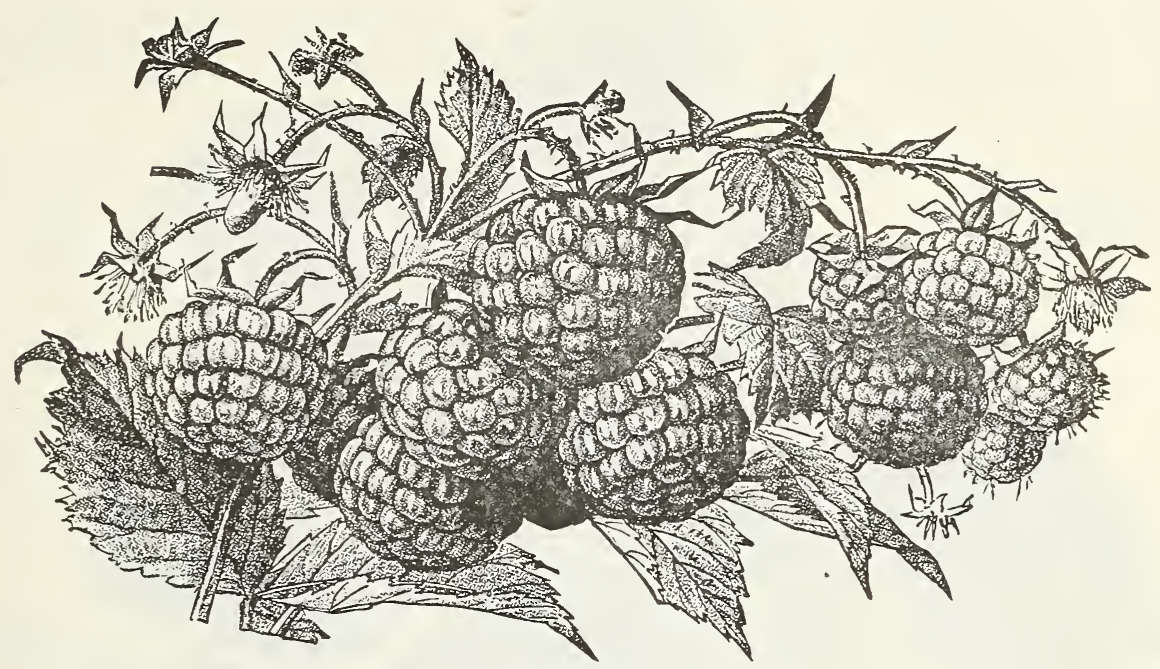

St. Regis.

Cumberland. A mammoth mid-season Black Cap that loads its stout stocky canes with handsome fruit. The great glossy berries outsell all others of their season, and are firm enough to ship well. Excellent quality. Many berries are seven-eighths of an inch in diameter. Hardiness, productiveness, size and quality make it desirable. Ripens a few days before the Gregg.

Cuthbert, or Queen of the Market. A remarkably strong, hardy variety, standing the northern winters and southern summers equal to any. Berries very large, conical, rich crimson; flavor is sweet, rich and luscious.

Thwack. Canes short, hardy as the hardiest, producing large crop of beautiful fruit; very firm, rendering it one of the best for shipping.

Louden. A seedling of Turner crossed with the Cuthbert; originated at Janesville. The fruit is large, resembling the Cuthbert in color and shape, but is firmer and of good quality; its fine appearance always commands the highest price in the market. The cane is strong, a vigorous grower, and resembles the Turner in aporous grower, and resembles the Turner in aplieve it is the one red raspberry for the garden and market.

Turner. A beautiful red berry of fine size and excellent quality. One of the hardiest and most productive varieties known.

Golden Queen. Best Yellow raspberry yet introduced. Briefly stated, it is a yellow Cuthbert of large size, great beauty, high quality, hardy and productive. Canes are of the strongest growth; no home garden complete without it; its beauty, size and quality render it indispensable for table use. Ripens in midseason.
Columbian. (Purple). This is the most vigorous grower of any raspberry in cultivation. The canes often reach one inch in diameter. No berry will surpass it for yield. The berries are very large, shaped like the Cuthbert and are better quality than the Shaffer. The best berry for canning we know; it is different from any other raspberry.

Cardinal. (Red). The most remarkable plant of cane growth yet introduced; canes not injured by temperature of 26 degrees below zero; color dark red, almost purple; very productive; berries large and round. The best of its kind.

St. Regis Everbearing Red Raspberry. An excellent novelty. Raspberries for four months! That's what you get when you plant the St. Regis, the new everbearing variety. Moreover, they are not only raspberries, but raspberries of the very highest grade-in size, in brilliant crimson color in firmness, in flavor. The variety has been aptly termed "the early till late" variety; for it is the first red raspberry to give ripe fruit, while it continues to produce berries without intermission until late October. St. Regis is of pure American blood and of ironclad hardihood. In addition to the brightest crimson color, and large size of the fruit, it is so firm, and rich in sugar that it will stand shipping two hundred miles, arriving at market in first-class order; and it can be readily kept in perfect condition for several days after being gathered. Unlike any other raspberry, the St. Regis yields a crop of fruit the season it is planted. Plants of it planted in early April gave ripe berries on June 20 th of the same year. For four weeks thereafter the berries were large and beautiful, firm and full flavored to the very last. 


\section{Blackberries}

In field culture plant in rows eight feet apart and three feet in the rows. In garden culture plant rows five feet apart and three feet distant in rows. The pruning should be governed by the growth of cane and should be severe. Pinch back the canes in summer when three feet high, causing them to throw out laterals. Cultivate for first season to get plants well established, then the ground between the rows may be mulched enough to keep down the weeds.

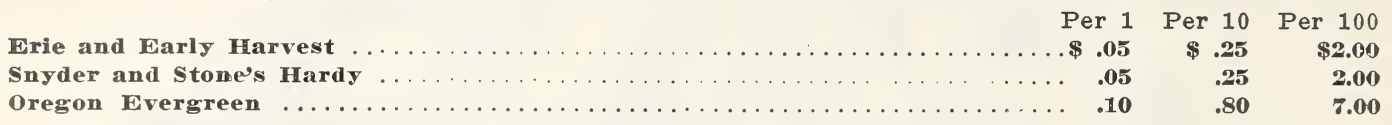

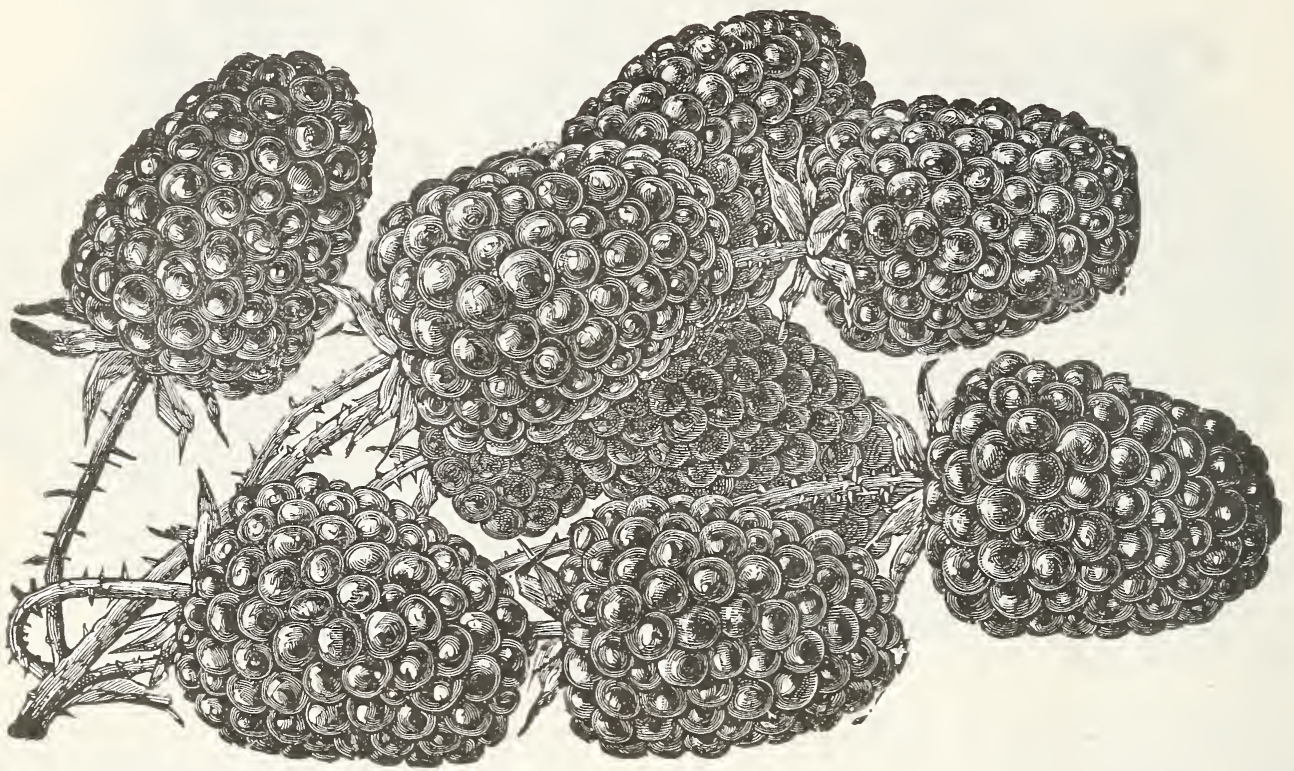

Oregon Evergreen.

Snyder. Very popular for the North and Northwest on account of the extreme hardiness. Wonderfully productive, size medium, fruit juicy and sweet, without the hard core of many sorts; canes remarkably strong and thrifty; more largely planted than any other of the ironclad varieties. We have a heavy demand for them every year. Season early.

Stone's Hardy. Upright grower; very hardy; the berry is black and glossy when ripe and has a delicious flavor. It commences to ripen its fruit about five days earlier than snyder, and continues bearing ten days longer.

Early Harvest. One of the earliest blackberries in cultivation, a compact dwarf grower, fruit rather small and of good quality, heavy bearer; its extreme earliness makes it a very profitable variety. Bloom stands the spring frosts best of all.

Oregon Evergreen. The Oregon Evergreen Blackberry is one of the good things that have come to stay with us and will prove a great boon to all lovers of the wholesome and luscious fruit. Everyone who has a dooryard or piece of ground, however small, can now have plenty of the sweetest and best blackberries at little trouble or cost, as this valuable new variety will thrive and bear immense crops of the most luscious fruit wherever it can get a foothold in the soil, and any kind of a trellis, arbor or support for the magnificent grape-like vines to run over. The Oregon Evergreen Blackberry differs from all other blackberries in form of its foliage and manner of growth. The canes do not die in winter like other blackberries, but continue to grow and bear year after year like a grapevine. The foliage somewhat resembles that of the fern and forms a remarkably handsome covering for arbors. The berries are borne in clusters of four or five on a stem, are good sized, fine flavored, sweet and delicious, either to eat from the hand, canning or cooking. They are immensely productive. No other blackberry will bear such heavy crops and continue fruiting so long in the season. 


\section{Dewberries}

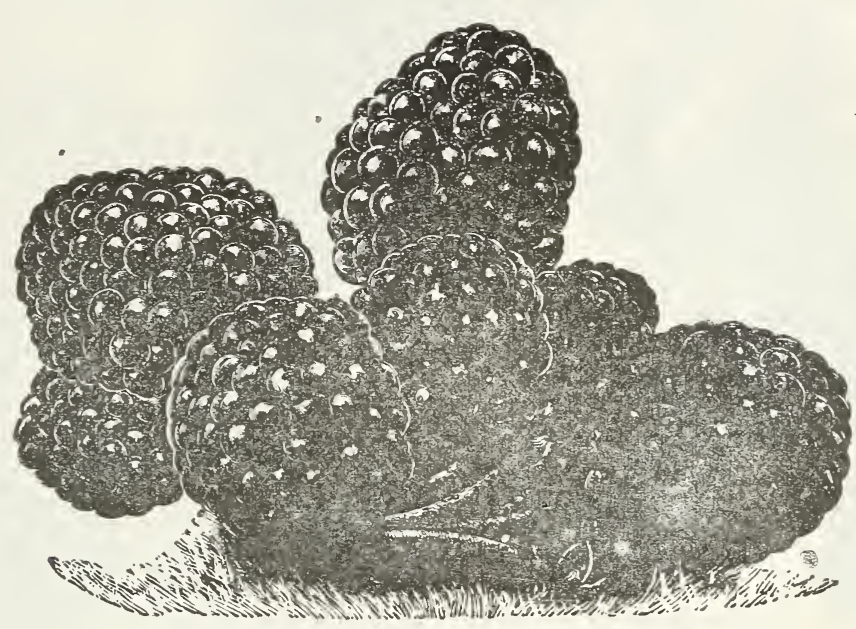

Lueretia Dewberry

Bartel's Mammoth. Fruit very large, luscious and handsome; perfectly hardy, a strong grower and enormously productive; a superb and very profitable market fruit. The vines should be allowed to lie on the ground in winter and staked up early in the spring.

Lueretia. This is the leading and most popular dewberry yet discovered; it succeeds everywhere and is not particular about the kind of soil. Berries very large, black and of fine flavor. It should not be picked oftener than twice a week, when it is very sweet and rich. It ripens with the last strawberries.

Price-5 cents each, 40 cents for $10, \$ 3.00$ fer 100.

\section{Himalaya Berry}

This berry is a new arrival from the North Slope of the Himalaya Mountains, 6,000 feet above sea level. It is black, but not a blackberry. For many centuries the natives of that country have been making wine of it, and only the invasion by British troops has brought this delightful, luscious fruit to our civilization. The vine is a vigorous grower, making a growth of twenty to thirty feet in one year, which can be trained on a fence or arbor similar to grape vines. The enormous clusters of large sized berries ripen all summer, making the Himalaya the most productive of any variety known. They have no core and the flavor is sweet, of unusual richness, and when ripe will literally melt in your mouth. For pies, jellies and dessert the Himalaya berry is a perfect success, being ahead of any similar fruit. The severity of their native climate has made the berries hardy, and both plant and fruit will stand extremes of heat and cold better than any other variety.

Price-10 cents each; 6 for 50 cents; 100 for $\$ 6.00$.

\section{Logan Berry}

Or Raspberry Blackberry. Originated in California in 1884 Supposed to be a cross between a red raspberry and a blackberry. In California for several years it has been grown in quantity for market and has been well tested in Eastern States. Vine is a strong grower, spreading like Dewberry, free from disease; canes large, exceedingly prolific; ripens very early. Fruit size of large blackberries, same form and shape; color bright red, seeds small, flavor combination of blackberry and raspberry; mild, pleasant, vinous, excellent. 20 cents each; 6 for $\$ 1.00$.

\section{Dwarf Service or June Berry}

Grows four to six feet high, bunches out from the ground like currants, resembles the common Service or June berry in leaf and fruit, but the fruit is larger and in color almost black; commencing to bear the second year after transplanting and bears profusely. No farm or garden should be without this most excellent dessert fruit. 


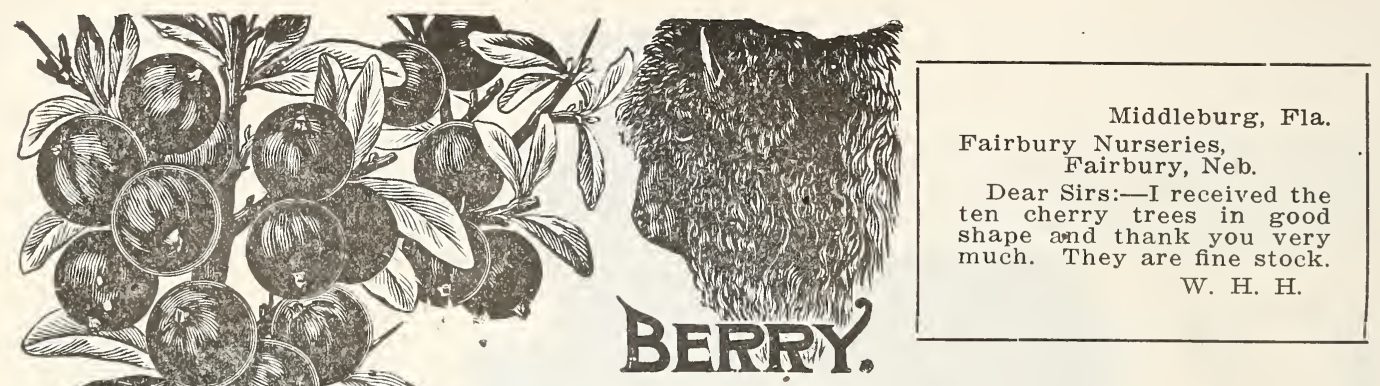

\section{Buffalo Berry}

The Buffalo Berry belongs to the Olive family of trees. It grows in bush form and sometimes attains a height of ten feet; its leaves are of bright silvery color, and with its load of red fruit, makes a nice shrub. It is perfectly hardy and bears immense crops of fruit, which is very good for tarts, jellies, pies and preserves.

It is sometimes called the winter currant from the fact that fruit remains on until January.

Price-2-foot trees 20 cents each; 6 for $\$ 1.00$.

\section{Japanese Wineberry}

This is an entirely new, distinct and valuable berry. It belongs to the raspberry family; is a strong, vigorous grower, attaining the usual height of the raspberry, and is said to be perfectly hardy in all positions without protection. The leaves are of the darkest green on the outside and silvery white underneath. The young shoots or branches are covered with a reddish brown hair or moss. The fruit is borne in large clusters, often seventy to one hundred berries in a bunch. These berries are, from the time of formation and bloom until they are ripe, enclosed in a "burr" which is caused by the calyx covering them entirely. When ripe the burr opens, exhibiting a large berry of the brightest, light glossy scarlet or cherry wine color. The burrs and stems are covered with a heavy reddish moss like a moss rose bud. The flavor of the fruit is entirely different from that of any other berry, being very sprightly, sweet and juicy, having no disagreeable sour, but a lusclous flavor peculiar to itself and superior to other berries. It commences to ripen early in July, and continues in bearing for a long time. It is the most prolific berry known, the bushes being literally covered with its luscious fruit. It is propagated from the tips like cap raspberries and dewberries, and can be increased rapidly.

Price-15 cents each; 12 plants for $\$ 1.00$.

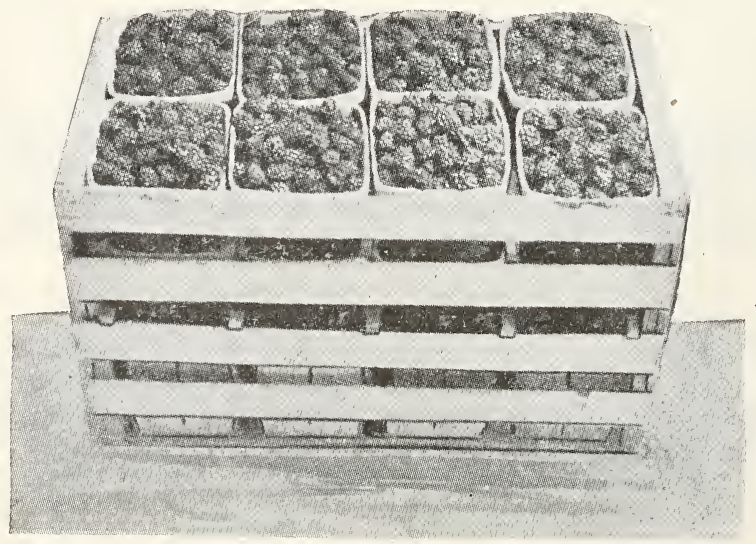



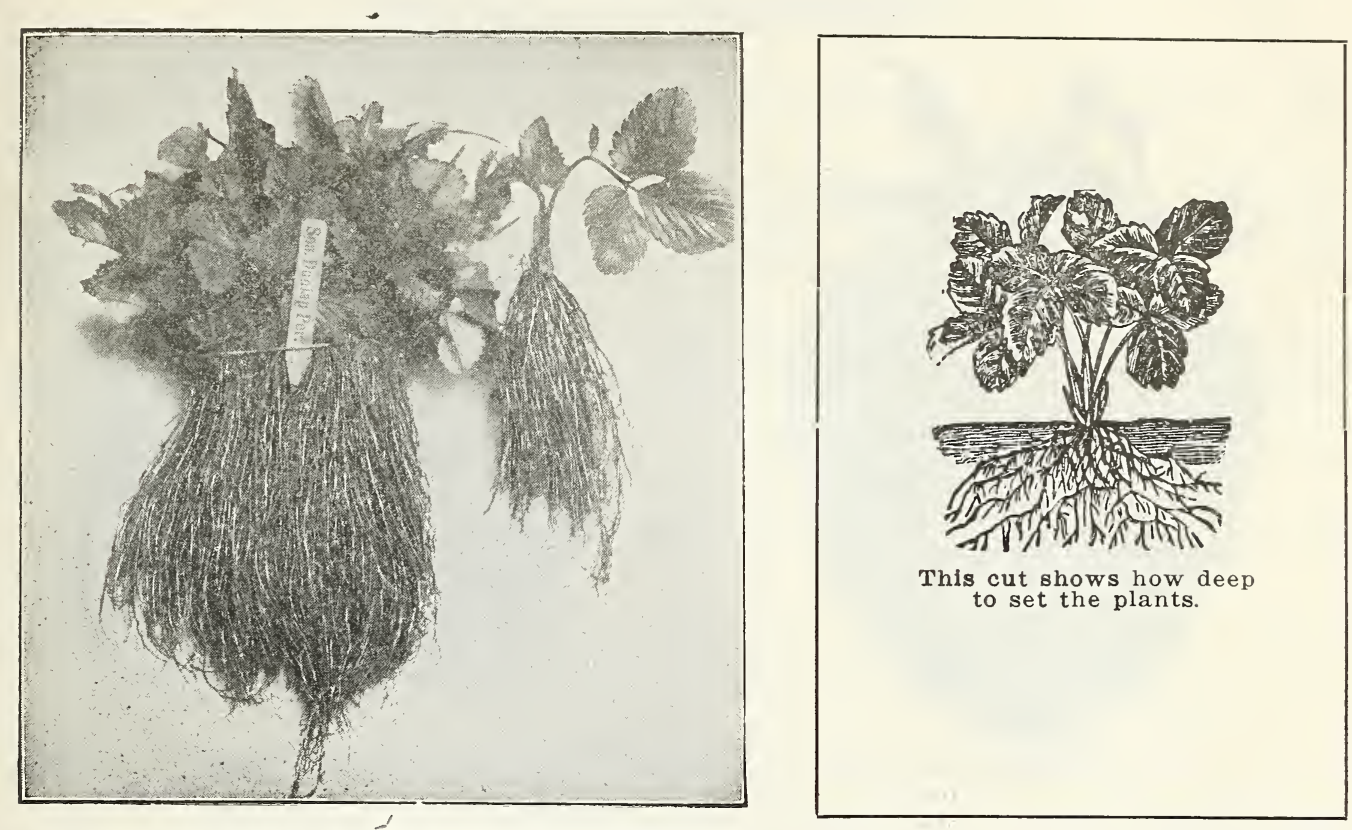

Notice the fine root growth of our plants.

\section{Strawberries}

The ground should be worked ten or fifteen inches deep and be properly enriched as for any garden crop. Drainage is necessary in very wet soil.

For family use plant fifteen to eighteen inches apart each way, and after a few strong plants have been set from runners, then pinch off all runners as fast as they appear. Keep the ground free from weeds and frequently stirred with a hoe or fork. Plants treated in this manner will produce more crowns and therefore double the amount of well-developed fruit than when runners are left to grow.

When the winters are severe, it is well to give the ground a light covering with coarse straw or litter. The covering should not be placed on until the ground is frozen. Fatal errors are made by putting on too much and too early. If coarse straw is used, it may be left on until the plants have done fruiting, taking care to open it up around t.e plants early in the spring, so as to give them plenty of sunlight and air.

Price-1 cent each; 60 cents per $100 ; \$ 4.00$ pe r 1,000 .

Price in September and October- $\$ 1.00$ per $100 ; \$ 6.00$ per 1,000 .

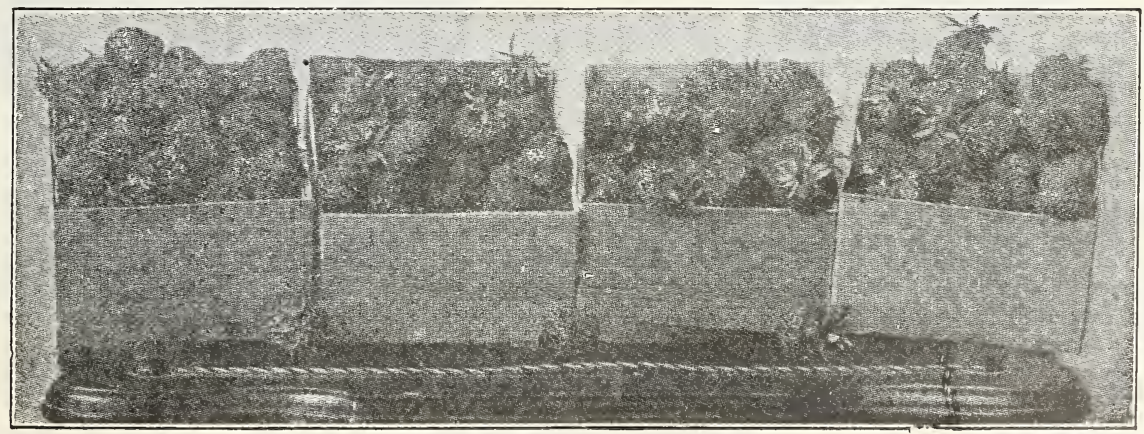




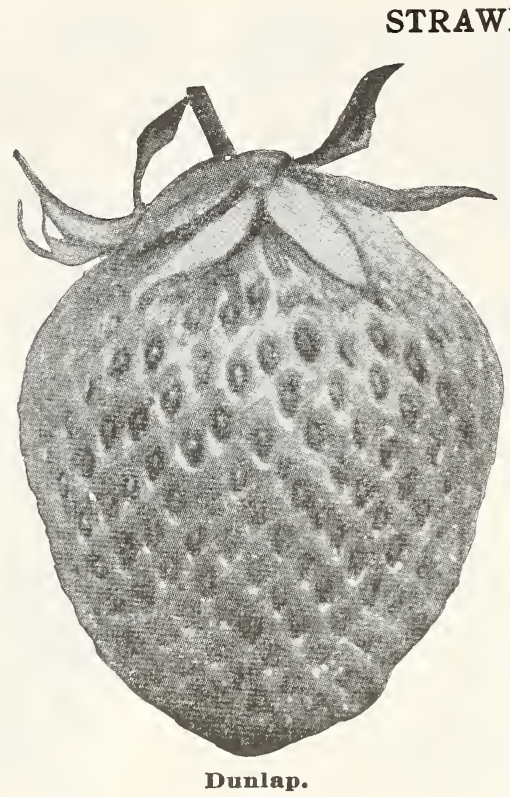

Beder wood. (Per.) Ripens a week ahead of Crescent; gives heavy pickings from the start, and holds out until the rush of mid-season.

Senator Dunlap. (Per.) A well-tested, wonderfully productive variety, one of the safe sorts to plant everywhere and sure to take a high place among the prominent standard sorts. Plant resembles Warfield, rampant runner, should be restricted in its production of plants, fully equal to Crescent and Warfield in its ability to succeed under all circumstances. Fruit good size, regular form, beautiful bright red, glossy, firm, splendid keeper and shipper, excellent quality. One of the best for canning; ripens early and continues a long time. It promises to stand at the head in its wonderful ability to ripen a good crop, under almost any condition of drought or neglect.

Crescent. Perhaps the most popular of all Plants strong, hardy and very productive; fruit extremely large, dark red, fine flavor. A splendid market variety. Imperfect.

Aroma. (Per.) Plants large, very vigorous and perfectly healthy. Makes plants just right for a good fruiting row. The blossom is rich in pollen, a good fertilizer for Sample, Bubach and Enormous. Fruit large to very large, roundish, conical, smooth and perfect in form, of a beautiful bright glossy red in color, very firm, and of excellent quality. Will give splendid results on any soil that will grow a good crop of corn or potatoes. It is nearly as late as Gandy, of long season. Three times as productive and a sure cropper every year. During the past five years the demand for plants of this variety has been very heavy and we have never been able to grow plants enough to meet this demand. Last spring we planted heavily to Aroma on new land

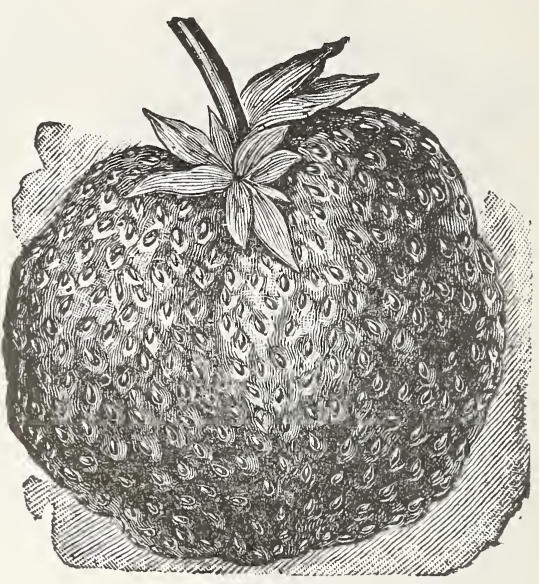

Gandy. and belleve we have plants sufficient to fill all orders which may come our way this season.

Gandy. (Per.) A well-known and popular variety which seems to do well under all conditions unless it be on light sand. It is of very high quality, good color, and a standard of firmness, qualities which make it desirable for either a home or market variety. It holds its size well from first to last, and although not as productive as some, it is a profitable sort, coming in after the glut, and prolongs the season. Does best on strong, moist, loamy soil.

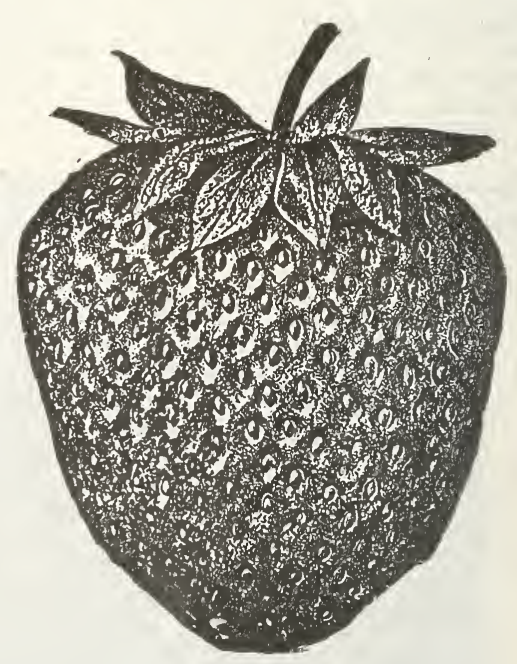

Aroma. 


\section{Everbearing Strawberries}

Ripe strawberries from June until November-this is what you can have by planting our everbearing sorts. We catalog only two varieties, which we have tested, and are considered among growers to be the best.

What lingering doubts may have been felt as to the practical value of this new race of strawberries are rapidly vanishing in the light of experience. There is now scarcely a discordant note in the general praise of their qualities for the home garden, and the developments of the present season indicate a greater value for the market garden than had before seemed probable. They have been on trial over a wide territory for about six years and the following points clearly demonstrated:

1st. Extreme health of foliage. Nothing approaching it has been exhibited by any of the old line varieties. This is especially true of the Progressive, which scarcely shows a rusted leaf while other varieties planted near it may be badly affected. All strawberry growers know that healthy foliage means capacity for heavy fruiting.

2d. Extreme hardiness of plant. Even the plants that by accident may have been left uncovered along the rows generally come through the winter in good condition.

3d. The plants produce a good crop the season they are set. The planter does not have to wait a year for returns; really only a few weeks. This enlarges the opportunity of tenant farmers, and those who must have fruit at once.

4th. They are the only early strawberry. Affords a good picking a week before the first early varieties of the old kind.

5th. The crop they bear in June compares well with the old varieties, especially in unfavorable seasons where frost or heat cuts the main crop.

6th. The quality is simply exquisite, far sweeter than the standard kinds that we have been growing for twenty years. In this matter Progressive is decidedly at the head.

7th. In addition to this list of qualifications the Progressive has proved a first-class plant maker. A great improvement over the everbearers first sent out. Not too much so for good fruiting, but making what would be called ideal matted rows.

Set plants same as common varieties of strawberries. To get plenty of fruit the first season, do not allow the plants to form any runners or bloom stalks until June 1st. By that time plants will be well established and able to produce a fine crop of fruit.

Progressive. (Per.) This is a vigorous thrifty grower, making a matted row 2 to 3 feet wide; in fact, the best plant maker of all the overbearing kinds, and on rich soil plants should be set at least two feet apart in the row. The color of the foliage, manner and habit of The color of the foliage, manner and habit of is medium to large in size, of a beautiful dark glossy red. Flesh red, firm and of good quality. It will produce as many berries in June as Dunlap or Warfield, and as it bears fruit on the new formed plants, it will continue to produce berformed plants, it will continue to produce ber-
freezes in the fall, but producing the most fruit freezes in the fall, but producing the most fruit about November 1. Just think of it; two crops in one year, with the fall crop selling for more than three times as much per crate as the spring crop And if the frost should get the blossoms in the spring the plants will immediately commence to produce other fruiting stems and will come right on with a good fair crop just as if nothing had happened. The frost cannot cheat you out of strawberries if you have the Progressive. You will never be sorry if you invest heavy in this variety.

Superb. (Per.) This variety makes large, beautiful, vigorous and thrifty plants, and just the right amount for a good fruiting row. Fruit is large to very large, of a beautiful bright crimson color, running very even for size and shape; in fact, a crate of them looks like each berry had been run in the same mold. The berry is firm and of good quality. This variety is preferred by many growers on account of its large size, even shape and good quality. Most growers would prefer one quart of large, smooth, high-colored berries to two quarts of small ones, and we feel a good deal like this ourselves. This kind does not run down small toward the last picking, like most other varieties, but holds

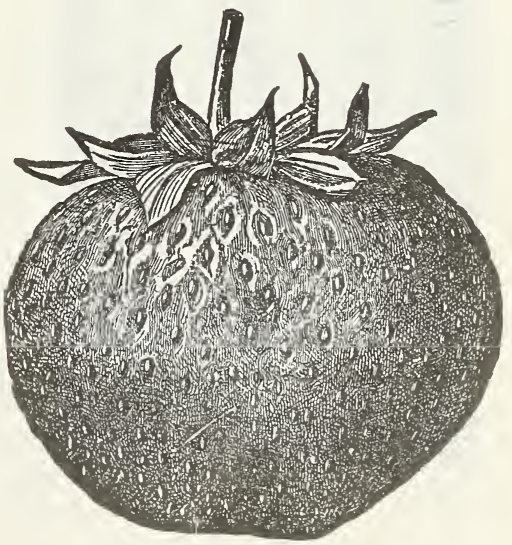

Superb.

its size remarkably well throughout the entire season. The Superb will command a fancy price in any market, from the first picking to the last, and you will make no mistake in ordering this variety. Price, 4 cents each; 50 plants, $\$ 1.25 ; 100$ plants, $\$ 2.00 ; 1,000, \$ 17.00$.

For cut of Progressive, see last page of cover. 


\section{Russian Mulberry}

This tree has been planted very extensively in the Western states for the past fifteen years, and we know of no other tree that will stand as much drouth and neglect and yet make a good growth each year.

It makes a very good shade tree, holding its leaves late into the fall; and for a hedge, without thorns, it has no superior.

Trees commence to bear at two years old; fruit resembles the blackberry, and will ripen from July ist to September.

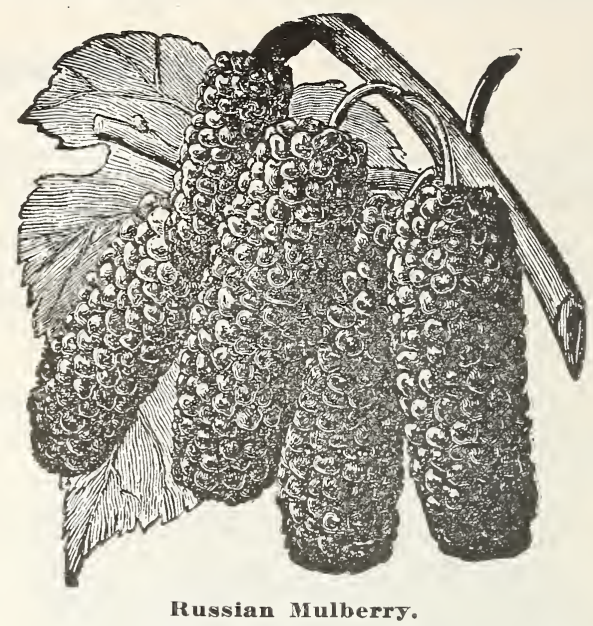

5 to 6 feet, well branched, transplanted

Per 1 Per 10 Per 100 Per 1,000

4 to 5 feet, well branched, transplanted

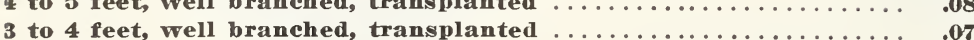

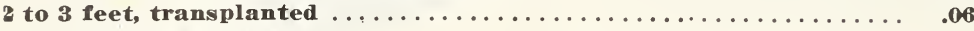

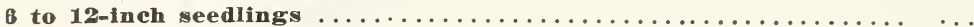

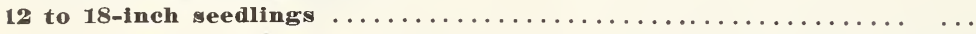

$\begin{array}{rrr}\$ 1.25 & \$ 10.00 & \ldots \\ .70 & 6.00 & \ldots \\ .60 & \mathbf{5 . 0 0} & \ldots \\ .50 & \mathbf{4 . 0 0} & \ldots \ldots \\ \ldots & .25 & \mathbf{2 . 0 0} \\ \ldots & .35 & \mathbf{3 . 0 0}\end{array}$

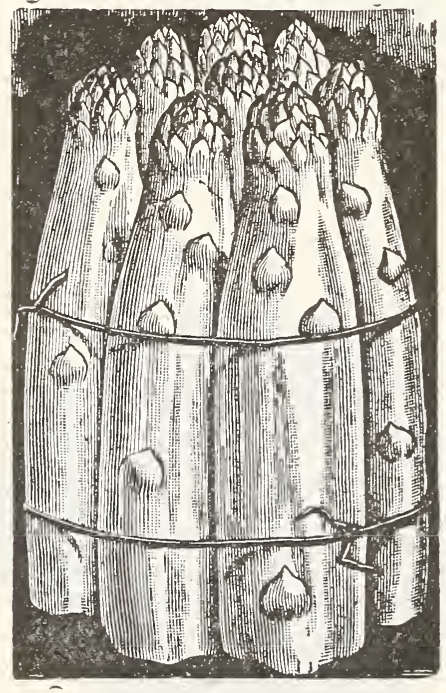

Colonaal.

\section{Asparagus}

To prepare a bed for planting, the soil should be dug deeply and well mixed together with well-rotted manure or compost. Plant in rows two feet apart. In the rows the plants should not exceed a foot apart, and planted about four inches deep. Cover on approach of winter with manure, and fork the bed over lightly in the spring. Price, 10 cents per 10; 75 cents per 100: $\$ 6.00$ per 1,000. Parcel Post 10-20 cents.

Conover's Colossal. A mammoth variety of vigorous growth, sending up from fifteen to twenty sprouts each year, from one to two inches in diameter; color deep green, and crown very close.

Palmetto. It is earlier, a better yield, more even and regular in its growth and quality, equal to the old favorite, Conover's Colossal.

\section{Rhubarb or Pie Plant}

This deserves to be ranked among the best early vegetables in the garden. It affords the earliest material for pies and tarts, continues long in use, and is valuable for canning. Make the border very rich and deep. Price, 10 cents per $1 ; 60$ cents per 10; $\$ 4.00$ per 100 . By Parcel Post 15 cents each.

Linnaeus. Large, early, tender and fine; the very best of all.

Victoria. The best for market because of its giant growth.

\section{Horse Radish}

Price, 3 cents per $1 ; 20$ cents per $10 ; \$ 1.50$ per 100. By Parcel Post 5 cents each.

\section{Elderberries}

A well-known bush which bears a fine fruit for pies or wine. Price, 15 cents each; 10 for \$1.00. By Parcel Post, 20 cents each. 


\section{Ornamental Department}

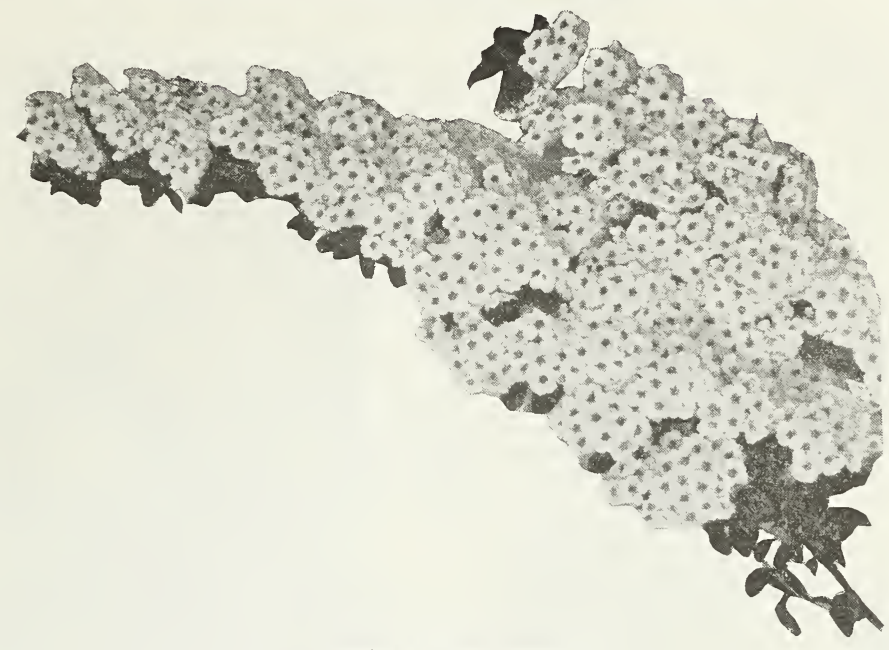

Spirea Van Houtel

\section{Ornamental Shrubs}

The judicious planting of shrubs adds greatly to the beauty and value of property, and contributes a wealth of pleasure and interest to the home. There are a few principles governing the artistic arrangement of these beautiful ornamentals, that should be more strictly observed. In general, individual specimens should rarely be isolated from the body of the design. Irregular groups or masses arranged against the buildings, fences or property lines, or as border plantations, along walks or drives, are much more effective. A good arrangement of shrubs invariably provides wide open stretches near the center of the lawn.

We have reduced our shrub list somewhat, omitting varieties for which, although very desirable in themselves, there is little demand.

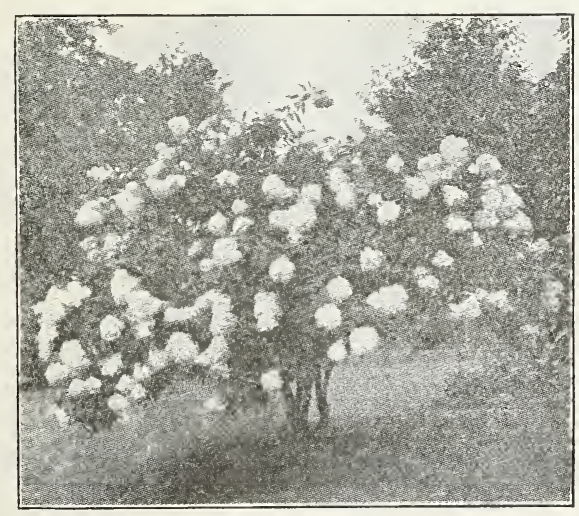

Snowball.

Althea or Rose of Sharon. These are fine shrubs and especially valuable because of their flowering in the fall when nearly all other shrubs are out of blossom. Hardy and easy of cultivation. 20 cents each. By Parcel Post 30 cents each.
Almond. Dwarf, double, rose-flowering. A beautiful shrub with small, double rosy blossoms closely set upon the twigs before the leaves appear. 20 cents each. By mail 35 cents.

Japan Snowball. A rare and exceedingly beautiful species from Japan. Flowers pure white, in very large globular heads. 2-foot trees. 35 cents each. $B y$ mail 50 cents.

Bechtel's Double-Flowering Crab. A mediumsized hardy ornamental tree of great beauty. When in bloom this tree presents the appearance of being covered with roses, fragrant flowers of immense size, sure to give satisfaction to those who plant this beautiful tree. 35 cents each. By mail 50 cents.

Calyeanthus. Sweet Scented Shrub or Allspice-An interesting shrub, having a rare and peculiar fragrance of wood and flowers, its blooms are abundant and of peculiar chocolate color. 25 cents each. By mail 35 cents.

Mock orange or Syringa. The Syringa is a large shrub, growing from 6 to 10 feet high. Vigorous habit, very hardy, with large handsome foliage and beautiful white flowers. Very fragrant. Blooms very freely. Hardy. 20 cents. By mail 30 cents.

Snow Ball. A well-known and favorite bush Snow Ball. A well-known and favorite bush of large size. Bears balls of pure white flowers in June. We have a bush on our farm on which everywhere. 20 cents each. By mail 30 cents. 


\section{ORNAMENTAL SHRUBS-Continued}

Hydrangea. A fine shrub of recent introduction, blooming from July to November. Large, showy panicles of white flowers in the greatest profusion. It is quite hardy and altogether a most admirable shrub for planting singly on the lawn or in the margin of masses. To produce largest flowers, it should be pruned severely in the spring and the ground enriched. 2-foot plants, 25 cents each. By mail 35 cents.

Tree Hydrangea. 4 to 5 feet high, 50 cents each. By mail 75 cents.

Spirea (Van Houttei). The best White Spirea. The annual growth is long and abundant, and covered in June with a wealth of pure white blossoms. Perfectly hardy. Should be in every collection. 20 cents each. By mail 30 cents.

Spirea. (Anthony Waterer). A small dwarfish grower, 15 to 18 inches high and covered the

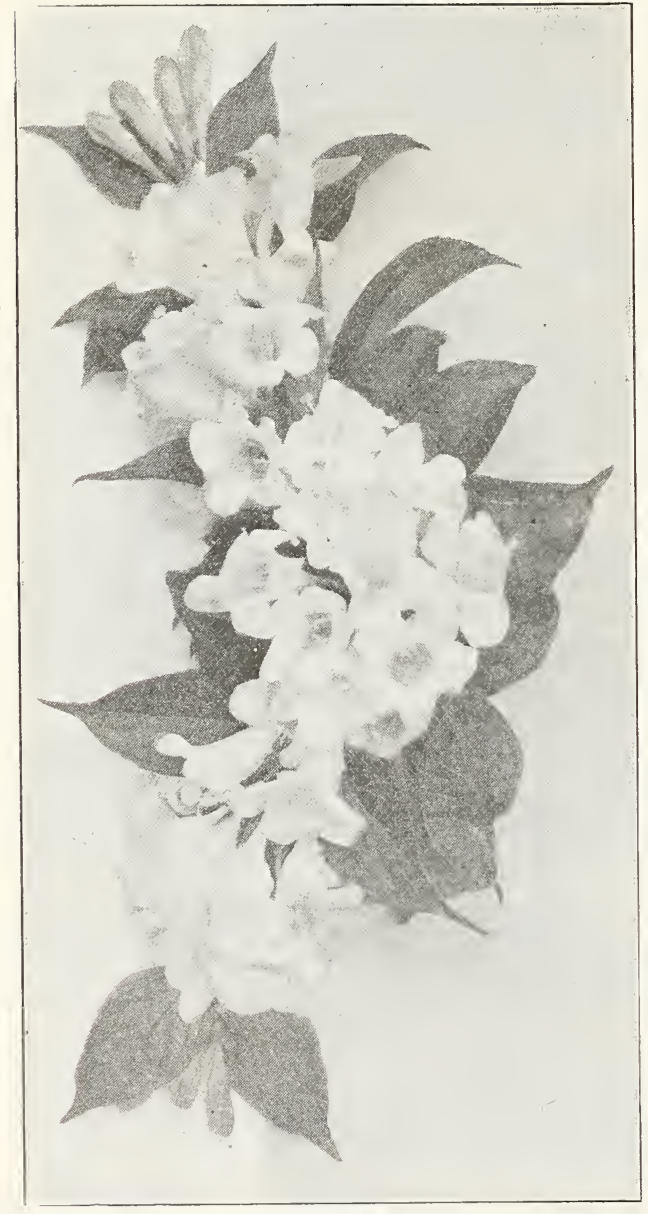

Weigelia.

entire season with large umbels of deep pink flowers. Quite hardy here and very desirable. 25 cents each. By mail 35 cents.

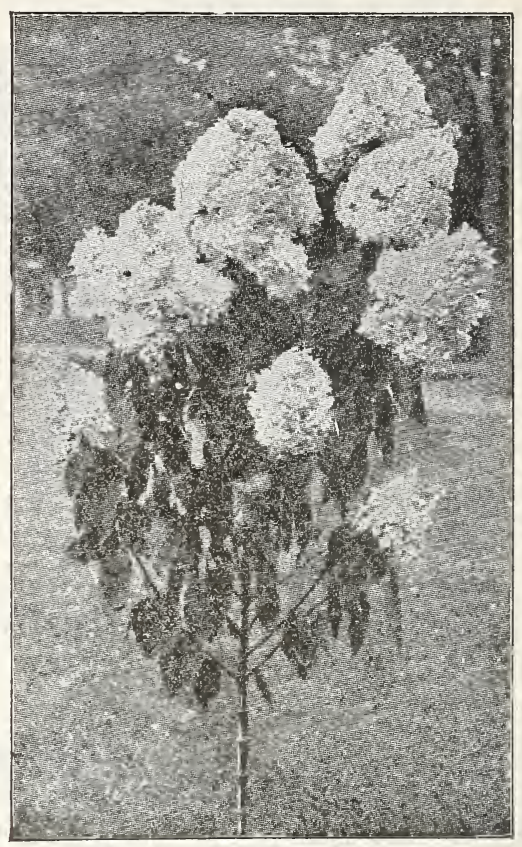

Tree Hydrangea.

Lilac, Persian Purple. With glossy green foliage and beautiful, fragrant flowers. A good plant for the lawn and one of the best for a fancy hedge. Hardy anywhere. Flowers purple. 20 cents each. By mail 35 cents.

Lilac, Persian White. Same as above, with white flowers. 20 cents each. By mail 35 cents.

Weigelia Rosea. Of Japan origin, producing a mass of flowers from July until fall. Very ornamental flowers, dark rose with lighter center. Very hardy. 20 cents each. By mail 35 cents.

Weigelia. (Eva Rathke.) Brilliant carmine in color, almost continuous bloomer, very fine. Price, 25 cents each. By mail 35 cents.

Forsythia. (Golden Bell.) Few, if any of the spring flowering hardy shrubs can surpass the splendor and brilliancy of the Forsythia. Both the grace and beauty give them a prominent place in all shrub plantations. Of upright, vigorous growth; foliage rich dark green and lustrous. Flowers brilliant golden yellow, borne in great profusion early in April before the leaves appear. 2 to 3 feet. 20 cents each. By mail 35 cents.

Butterfly Bush. One of the most desirable summer flowering shrubs, beginning to bloom in July it continues until cut by severe frost. The flowers are of a pleasing shade of violet-mauve, and are borne in dense cylindrical spikes, which, under liberal cultivation, are from twelve to fifteen inches in length by three inches in diameter; it suceeds everywhere and flowers freely the first season planted, and is always admired. Price, 25 cents each; by mail 35 cents. 


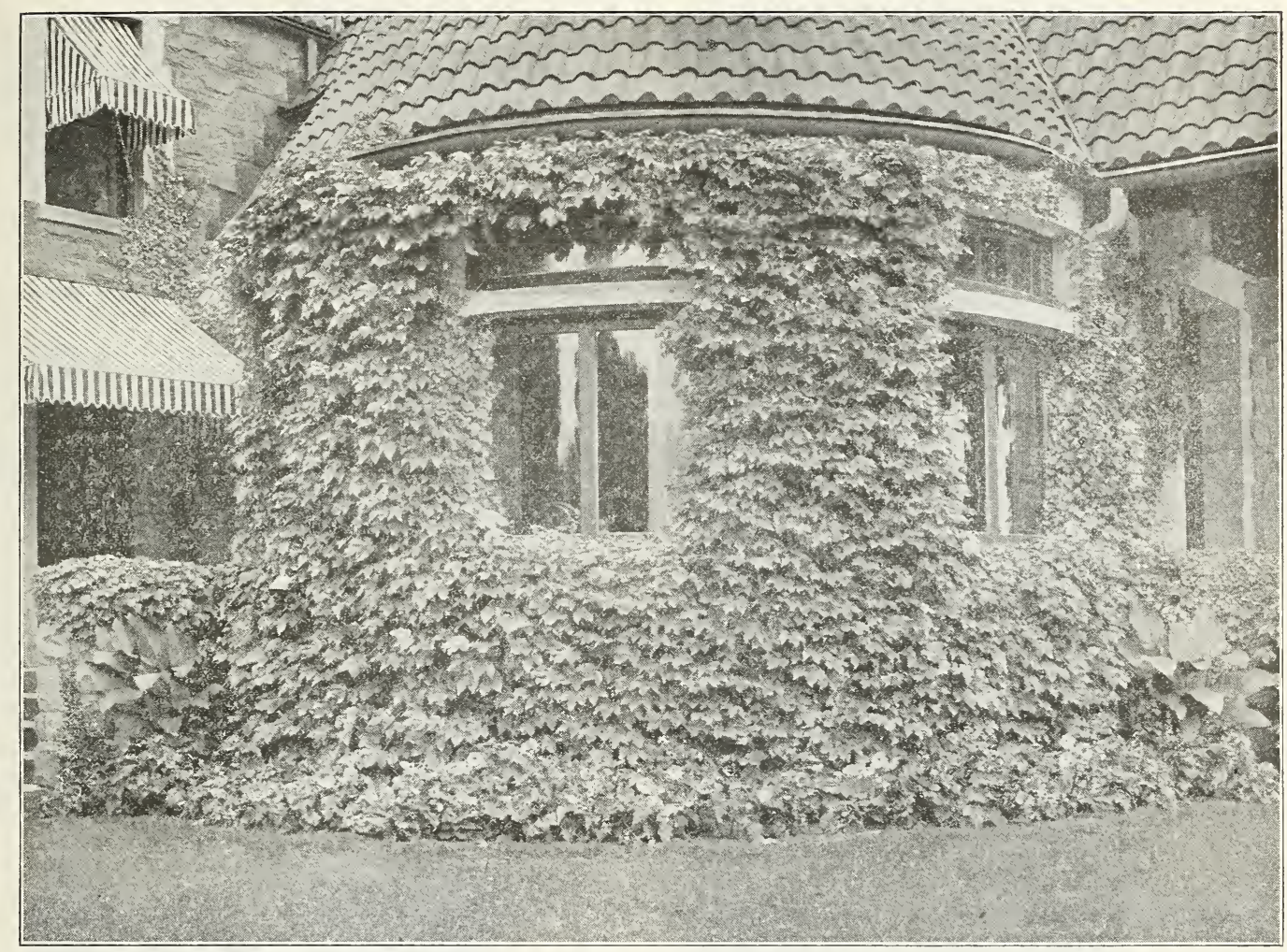

Boston Ivy.

\section{Climbing Vines}

Clematis Paniculata. (New Sweet Scented Japan Clematis.) No introduction of recent years has met with such ready sale, and given so perfect satisfaction wherever planted. It grows and thrives anywhere and is a very rapid grower and profuse bloomer. The flowers are pure white. Its extreme hardiness, bright green foliage and delightfully fragrant flowers serve to make this one of the finest hardy climbing plants in cultivation. Strong 2-year plants, 25 cents. By mail 35 cents.

Clematis. (Jackmanii.) A very beautiful blooming variety, with flowers from four to six inches in diameter, of an intense violet purple color, borne successfully in continuous masses on the summer shoots. 35 cents each. By mail 45 cents.

Henryi. Fine large, creamy white flowers, strong grower and very hardy. One of the best of white varieties. A perpetual bloomer. 40 cents each. By mail 45 cents.

Clematis. (Mad. Andre.)..Red, very strong grower, producing large flowers. 35 cents each. By mail 45 cents.

Honeysuckle. (Monthly Fragrant or Dutch.) Blooms all summer, very sweet. Red and yellow flowers. 20 cents each. By mail 30 cents.

Bigonia or Trumpet Flower. (Scarlet Radicans.) A splendid climber, vigorous and hardy, with clusters of large trumpet-shaped scarlet cents.
Virginia Creeper. A native vine of rapid growth, with large luxuriant foliage, which in the autumn assumes the most gorgeous magnificent coloring. The blossoms, which are inconspicuous, are succeeded by handsome dark blue berries. The vine is the best calculated to take the place in this country of the celebrated English Ivy, and is really in summer not inferior to it. 25 cents each. By mail 35 cents.

Wistaria. (Double Purple.) A rare and charming variety, with perfect double flowers, deeper in color than the single, and the racemes of remarkable length. The plant is perfectly hardy, resembling the single Wistaria, so wellknown as one of our best climbing plants. 20 cents each. By mail 30 cents.

Boston Ivy. A beautiful hardy climbing plant. This is one of the finest climbers we have for covering walls, as it clings firmly to the smoothest surface, covering it smoothly with overlapping foliage, giving it the appearance of being shingled with green leaves. The color is a fresh deep green in summer, changing to the brightest shade of crimson and yellow in autumn. It is quite hardy and becomes more popular every year. Strong plants, 25 cents each. By mail 35 cents.

Hall's Japan Honeysuckle. This beautiful honeysuckle is almost evergreen, very strong and hardy in growth. The flowers are delightfully fragrant, and bloom profusely from May until frost; a handsome and valuable vine. 15 cents each. By mail 25 cents. 
Cinnamon Vine. (Diascorea.) This beautiful climber possesses the rate quality of emitting from its flowers the delightful odor of cinnamon. Perfectly hardy, the stem dying down every autumn, but growing again so rapidly as to completely cover any trellis or arbor very early in the season. With its beautiful heart-shaped leaves and clusters of delicate white flowers, it is a most desirable climber. Price-Strong roots, 10 cents each. By mail 15 cents.

Bitter Sweet. (Celastrus Scandens.) A native climber with handsome, glossy foliage and large clusters of beautiful orange crimson berries remaining all winter. Very bright in effect and charming for winter house decorations. Very hardy. Price-Strong plants, 25 cents each; 10 for \$2.00. By mail 35 cents each.

Madeira Vine. Also called Mignonette Vine and Mexican Vine A beautiful tuberous rooted climber, with glossy green leaves and handsome racemes of fragrant white flowers. The vines make rapid growth, and a few plants will cover a trellis or cottage wall in a single season. Will grow anywhere without care. Price, strong roots, 5 cents each; 12 for 50 cents; by mail, 7 cents each.
Chinese Matrimony Vine. (Lycium.) Vigorous growing, hardy climbing vine that may be used anywhere that a vine is needed for training to trellis, fence or wall. The foliage is of a grayish green. The flowers, which appear from June to September, vary through shades of pink to purple. The fruit which follows is of a deep crimson color and very showy. It is borne abundantly along the branchlets. It is especially attractive in the fall, when it is thus loaded with its bright fruit, which contrast well amid the green foliage. The foliage remains fresh until severe frosts. Will grow in nearly all soils and in all climates. Price, 20 cents each; 10 for $\$ 1.75$.

Japanese Kudzu Vine. Jack and the Bean Stalk Vine. (Pueraria.) The most remarkable rapid-growing hardy perennial extant. In rich soil the plant will grow 70 feet in one season. Starts into growth slowly, but after three or four weeks it grows almost beyond bellef. Leaves in shape like Lima Beans; dark green, soft and woolly. For porches, arbors, old trees, etc., we know of nothing its equal. Price, 25 cents each; 5 for $\$ 1.00 ;$ by mail 30 cents each.

\section{Roses}

Our roses are all very strong two-year-old plants, either grown on their own roots or budded on Manetti, and are not to be compared with the puny greenhouse roses from two-inch pots sent out by some nurserymen.

\section{Climbing Roses}

Crimson Rambler. The famous crimson clustered climber, so extremely effective when grown on pillars and trellises. The plant is a vigorous grower, making shoots 8 to 10 feet in a season. The foliage is large and glossy, the plant looks like a mass of double crimson flowers when in bloom. The panicles are large and remain perfect for several weeks. Perfectly hardy anywhere. Price, 25 cents each; by mail, 30 cents.

Yellow Rambler. Flowers of medium size, in immense clusters, very sweet scented; a clear, decided yellow. The hardiest of all yellow climbing roses. It is a rampant grower, well established plants often making a growth of 10 to 12 feet in a season. 25 cents each; by mail, 30 cents.

White Rambler. Resembles Crimson Rambler in foliage and habit; flowers pure white. 25 cents each; by mail, 30 cents

"Baby Rambler." A dwarf (bush, not climbing) form of Crimson Rambler, and furthermore, ever-blooming. Will bloom continucusly throughout the summer if planted out of doors. Has the same bright crimson color as the Climbing Rambler, and blooms in clusters of 20 to 40 flowers at one time on plants of fair size. Baby Rambler is one of the best red roses for bedding and is going to be just as popular and as extensively planted as the climbing form has been. May be grown in pots. Two-year plants, 33 cents each; by mail, 40 cents.

Baltimore Belle. Pale blush, is almost white; very double and fragrant. 20 cents each; by mail 25 cents.

Greenville, or Seven Sisters. Purple crimson and pink, not quite hardy. 20 cents each; by mail 25 cents.

Queen of the Prairie. Bright rose color; large and double; very vigorous and rapid in its growth; the best climbing rose. 20 cents each; by mail 25 cents.

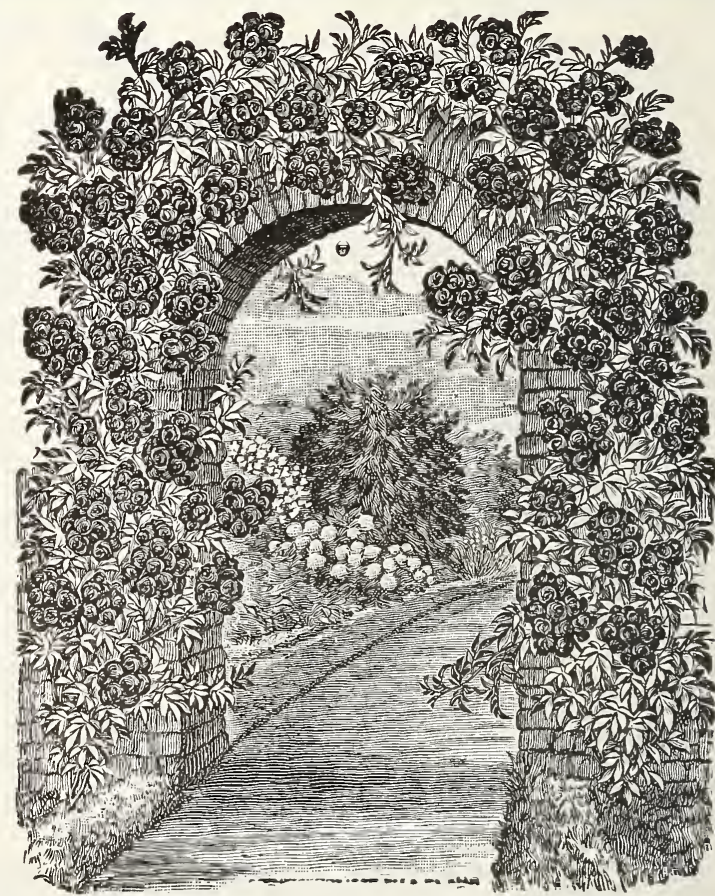

Crimson Rambler 


\section{A Blue Rose}

The Greatest Rose Novelty of the Century

The New Rambler. (Violet Blue) hailed by the German rose growers as the forerunner of a genuinely cornflower blue rose, is a seedling of Crimson Rambler, very vigorous and hardy and free blooming. 50 cents each; by mail 55 cents.

\section{New Ever-Blooming Crimson Rambler Rose}

A sort of the well-known and famous Crimson Rambler climbing rose. This new rose produces its lovely flowers until killing frost stops further growth of the plant. The flowers are produced in great trusses, each carrying from thirty to forty blossoms of the brightest crimson, which remains undimmed to the end. Combined with the waxy, pale green, red veined foliage, the glowing crimson mass of bloom make an irresistable effect. The new Ever-blooming Crimson Rambler produces its flowers on the ends of new shoots, and if cut as soon as faded, many new side branches will form, which soon are covered again with a great mass of blossoms. By blooming so constantly, the new shoots are not as large as with the old Crimson Rambler, but the wood is more firm and less subject to mildew, another point in its favor. The plant is exceedingly hardy, having successfully withstood the test in exposed situations of very severe winters. A magnificent ever-blooming rose for covering trellises, walls, porches, etc. as they succed under any circumstances and bloom wonderfully profuse throughout the summer. It is one of the finest and best novelties of recent introduction and will be very popular Price, 25 cents each; by mail 30 cents.

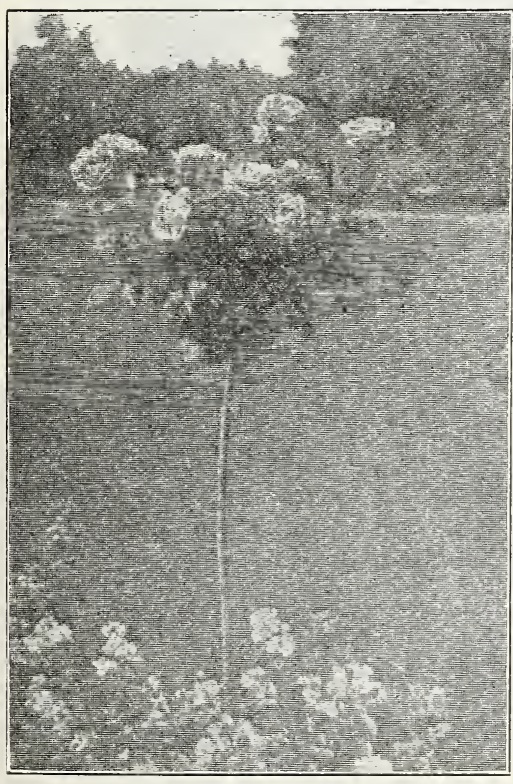

Tree Rose.

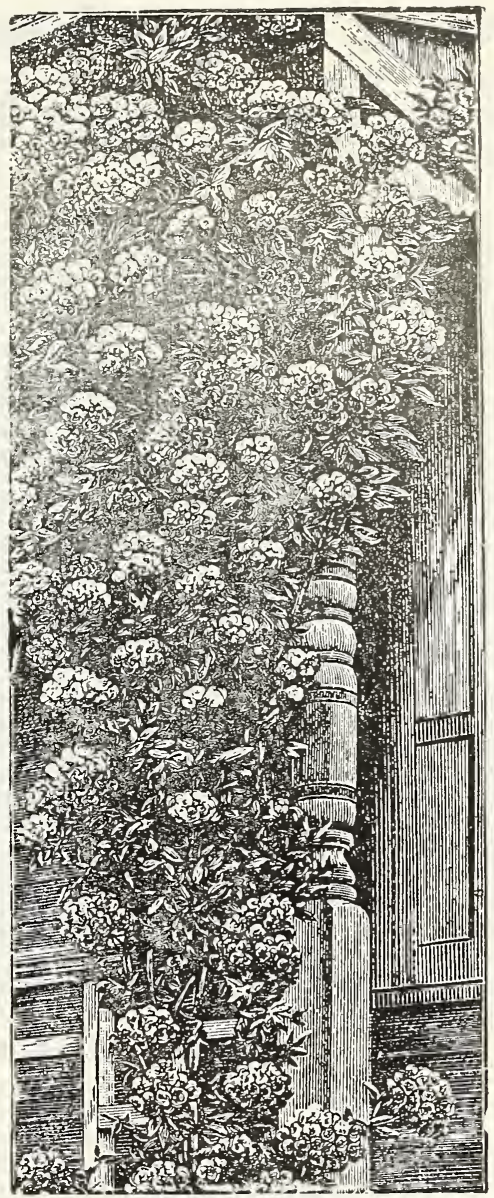

Ever-Blooming Crimson Rambler

\section{Tree Roses}

These are grafted on hardy rose stalks 4 to 5 feet high, are tree-shaped and when in full bloom are objects of beauty, making handsome plants for the lawn, or as border plants along the sidewalk or driveway. They are coming into popular favor and at the low price we are offering them this year anyone can set out a few of these pretty tree roses in his yard or on the lawn.

Crimson Rambler Tree Rose. No other rose is so well adapted for growing in tree form. The branches droop gracefully and reach nearly down to the ground, thus forming a regular weeping tree. 75 cents each; by mail \$1.00.

Hybrid Perpetual Tree Rose. These hardy and free-blooming roses we have in tree form and can furnish the following colors: Red, white and yellow. 75 cents each; 10 for $\$ 6.50$; by mail $\$ 1.00$ each.

\section{Memorial Rose}

Baby Rambler Tree Rose. A most attractive novelty in hardy roses. Budded on strong, straight stems four feet high; the round, bushy Baby Rambler tops at all times a perfect mass of crimson bloom. The most florescent and striking of all tree roses. \$1.00 each; by mail $\$ 1.20$ each.
A rose of trailing habit, a very hardy and rapid grower, with a glossy foliage, which remains on until late in the fall. Its flowers are pure white and very fragrant. It is especially adapted to cemetery planting, hence its name; or it may be trained as a screen to hide some unsightly root, stump or rock. 20 cents each. 


\section{Monthly Blooming Roses}

Marshall P. Wilder. Color bright cherry carmine, fragrant, of vigorous growth, with fine foliage, one of the freest of the hybrid perpetuals to bloom. We can recommend this rose without hesitation. 25 cents each; 5 for $\$ 1.00$; by mail 30 cents.

Paul Neyron. Deep rose color, splendid foliage and habit, with large flower. 25 cents each; 5 for $\$ 1.00$; by mail 30 cents each.

Ulrich Brunner. The flowers are very large, of beautiful form and very double; color, deep, rich rose. 25 cents each; 5 for \$1.00; by mail 30 cents each.

Anne de Diesbach. Carmine, beautiful shade, moderately full and very large. 25 cents each; 5 for \$1.00; by mail 30 cents each.

Madame Plantier. One of the finest pure white roses, blooming in clusters. 20 cents each; 6 for $\$ 1.00$; by mail 25 cents each.

Persian Yellow. Deep golden yellow; double and very fine. 30 cents each; by mail 35 cents each.

Coquettes des Blanches. Pure white, flowering in clusters, very free bloomer. 25 cents each; 5 for $\$ 1.00 ;$ by mail 30 cents each.

Gemeral Washington. Brilliant rose, crimson, double, fine. 25 cents each; 5 for $\$ 1.00$; by mail 30 cents each.

General Jacqueminot. Brilliant crimson scarlet, very showy and effective. 25 cents each; 5 for $\$ 1.00$; by mail 30 cents each.

Kaiserin Augusta Victoria. The finest white ever-blooming hardy garden rose. Soft, pearly

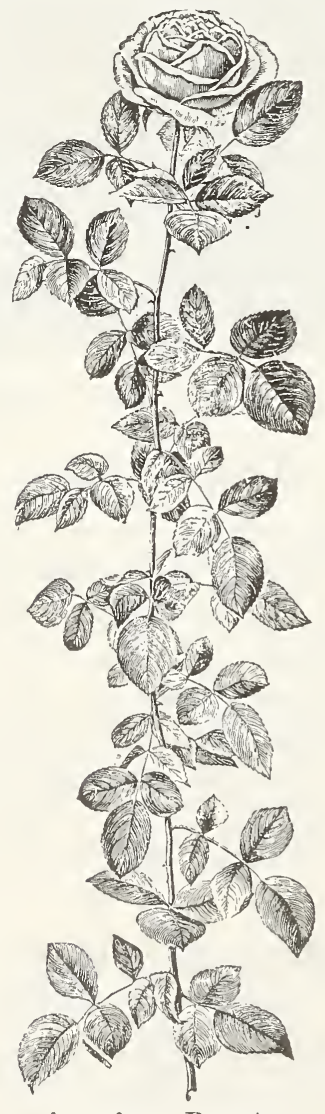

American Beauty white, lightly tinted with lemon in the center, just enough to relieve the white. Remarkably fragrant buds and open flowers of elegant form The plant is a strong grower, blooms freely, the flowers are carried on long, stiff stems. Best rose for garden and house. 25 cents each; 5 for $\$ 1.00$; by mail 30 cents each.

Madam Chas. Wood. One of the most beautiful hybrid perpetual roses ever introduced. flower Ig extra large, full and double, color deep

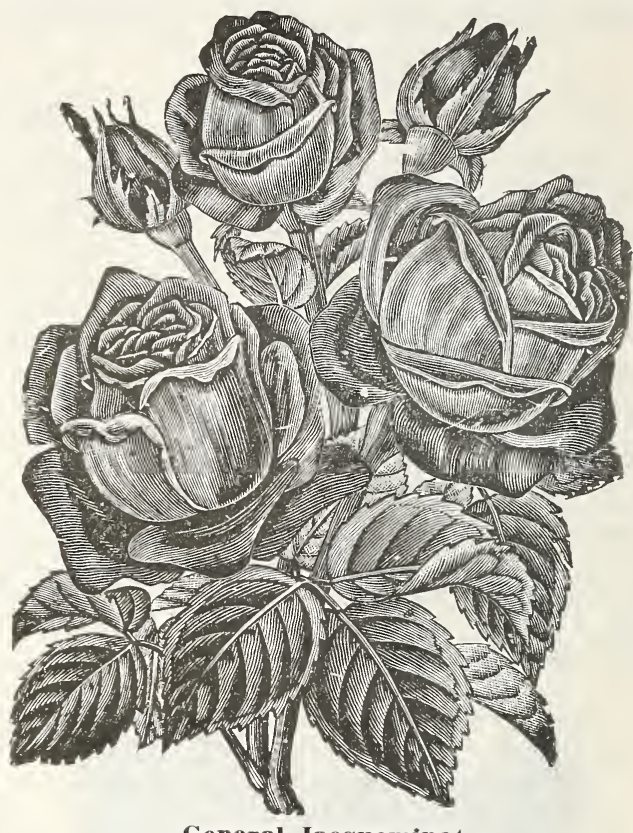

General Jacqueminot

rose crimson, sometimes brilliant scarlet with maroon shading, it blooms soon after planting out and continues to bloom all summer. 20 cents each; 5 for $\$ 1.00$; by mail 30 cents each.

American Beauty. One of the best and most valuable roses, both for garden and house culture. Color rosy crimson, exquisitely shaded and very handsome. Extra large, full flowers and fine buds. The plant is very hardy and id constant bloomer. Each shoot produces a bud. The fragrance is delightful. Vigorous growth and have the ever-blooming qualities of the Tea Rose. 35 cents each; by mail 40 cents each.

Frau Karl Druschki or White American Beauty. A pure paper white, free fowering large size Hybrid Perpetual. It is a remarkably handsome plant with bright, heavy foliage and strong, upright growth. The bloom is perfect in form on fine, long stems, and of the purest possible white. There is nothing in the line of perfectly hardy roses that can compare with this one in form, color and general finish. Twoyear old field grown, 35 cents each; by mail 40 cents each.

\section{Moss Roses}

The Moss Rose is as hardy as any rose can be, and an extra vigorous grower. They are much admired on account of their bright, heavy foliage and mossy-like covering of the buds. While they bloom but once a year, the flowers are large, beautiful and plentiful.

Capt. John Ingram. Dark, velvety purple, full and fine 25 cents: by mail 30 cents.

Glory of Mosses. Pale rose, very large, full and beautiful. 25 cents each; by mail 30 cents. Perpetual White. Pure white. It blooms in large clusters. 25 cents each; by mail 30 cents.

We pay the freight. See page 4. 


\section{Weeping Deciduous Trees}

The trees form objects of great beauty when planted as single specimens on lawns, in the front yard, and especially when used for cemetery decorations. Also of great value for covering arbors. All are invaluable for the variety they add to landscape and garden. Our list embraces the best varieties.

Teas' w e e p in $\mathbf{g}$ Mulberry. The most graceful hardy weepgrace in existence. ing tree in existence. Forms a perfect umwith long, slender, willo wy branches, drooping to the ground. It has beautiful foliage, is wonderfully vigorous and healthy; is one of the hardiest, enduring the cold of the North and the heat of the South; safe and easy to transplant; admirably adapted for ornamental, small or large grounds or for cemetery strong trees, Fine, strong 6 trees, high. Price, \$1.00 each.

Weeping Mountain Ash. One of the bestAsh. One of the bestular weeping trees. It is of easy culture, great hardiness and thrives in all soils. Its straggling: branches, twisting and turning in every direction, with no training whatever, make a most picturesque and nove 1 sight. Covered during the autumn with bright red berries. It is the best tree for the North of the extremely pendulous type. A

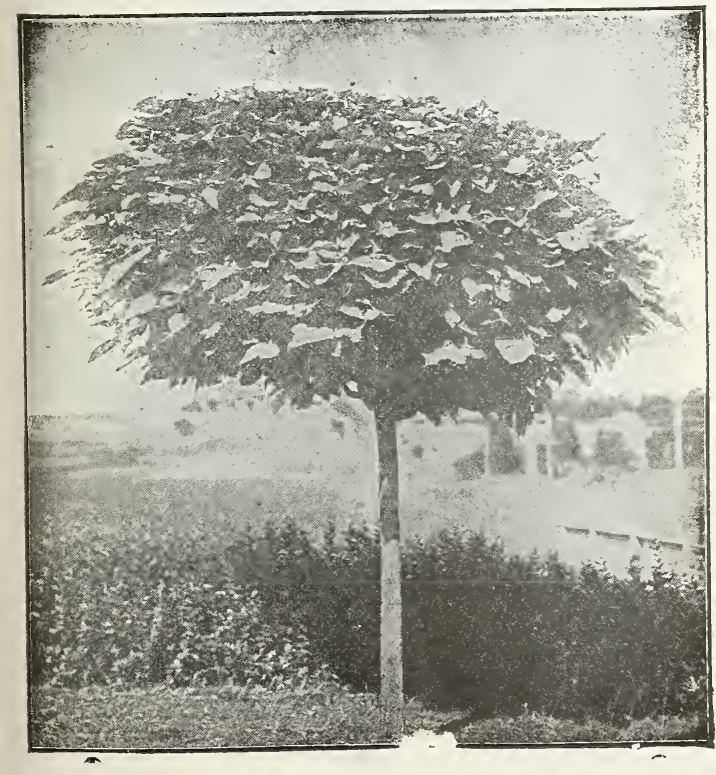

Bungeii Catalpa

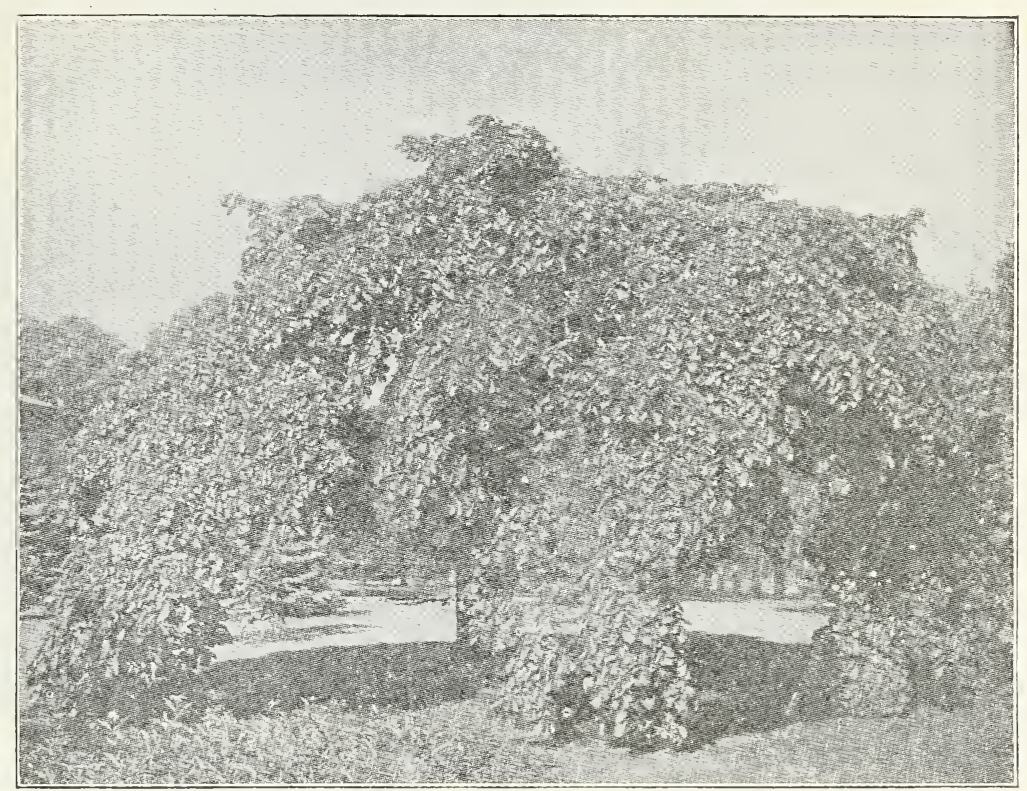

Camperdown Elm

splendid lawn tree. Grafted 6 feet high. Price, so cents each.

Cut-Leaf Weeping Birch. (Betula.) This magnificent tree is, without question, the most popular and the most planted of all the pendulous or so-called weeping trees. It is a tall, slender tree, yet with vigorous growth. It has an erect central trunk, somewhat pyramidal in shape, with graceful, drooping branches and glistening silvery white bark. The foliage is fine, thin deeply and delicately cut, and of a beautiful shade of green. The whole tree presents a soft and delightful effect not found in any other hardy ornamental tree. Price, 5 to 6 feet trees, 80 cents each; 6 to 8 feet trees, $\$ 1.00$ each.

Camperdown Weeping Elm. Its vigorous branches, which have a uniform habit, over-lap so regularly that compact, roof-like head is formed. Leaves are large, and a rich, glossy dark green. Tree a strong, vigorous grower One of the best weeping trees. It can be trained to form an arbor if desired. The peculiar characteristics of this tree make it very popular and valuable for the lawn. Hardy everywhere and not particular as to soil. With age the weeping branches will form a shady place as effectively as an arbor. This tree thrives splendidly. Price, $\$ 1.00$ each.

Wisconsin Weeping Willow. Of drooping habit and said to be perfectly hardy in the Northwest. 4-foot trees, 20 cents each; 5-foot trees, 25 cents each.

Catalpa Bungeii or Umbrella Tree. One of the finest ornamental trees we have; it is perfectly hardy; you will be pleased with this tree on your lawn. Trees grafted, 7 feet high, 75 cents each. 


\section{Ornamental and Shade Trees}

These trees are too large to go by parcel post.

Ash. A rapid growing native tree, of fine symmetrical outline. Very hardy and drouth resistant. Good street or park tree.

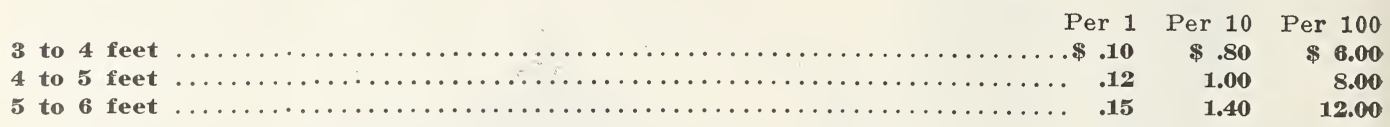

Mountain Ash. Hardy tree of medium size, a smooth bark, head dense and regular, covered from July till winter with large clusters of bright red berries. A fine lawn tree and very hardy.

4 to 5 -foot trees, each 25 cents; $10 \$ 2.00 ; 5$ to 6 -foot trees, each 30 cents; $10 \$ 2.50$.

White Birch. A graceful tree with silvery white bark and slender branches. When a few years old, of an elegant drooping habit, rendering the tree very effective in parks or on lawns. Very hardy, even as far north as the Dakotas.

Price-4 to 5 -foot trees, each 20 cents; 10 for $\$ 1.75 ; 5$ to 6 -foot trees, each 25 cents; 10 for $\$ 2.00$.

Box Elder. A small native tree, maple-like in its seeds and ash-like in its foliage. Of spreading habic, rapid growth, very hardy, desirable for street planting, and succeeds in many places where other varieties do not thrive.

Price of Box Elder Trees:

Per 1 Per 10 Per 100

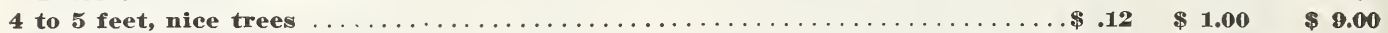

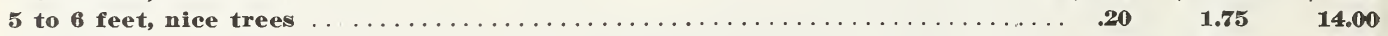

6 to 8 feet, nice trees

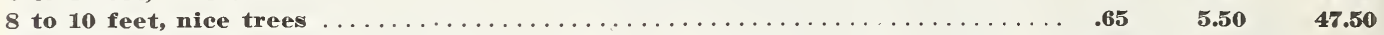

10 to 12 feet, nice trees $\ldots \ldots \ldots \ldots \ldots \ldots \ldots \ldots \ldots \ldots \ldots \ldots \ldots \ldots \ldots \ldots \ldots \ldots \ldots \ldots .25 \quad 10.00 \ldots$

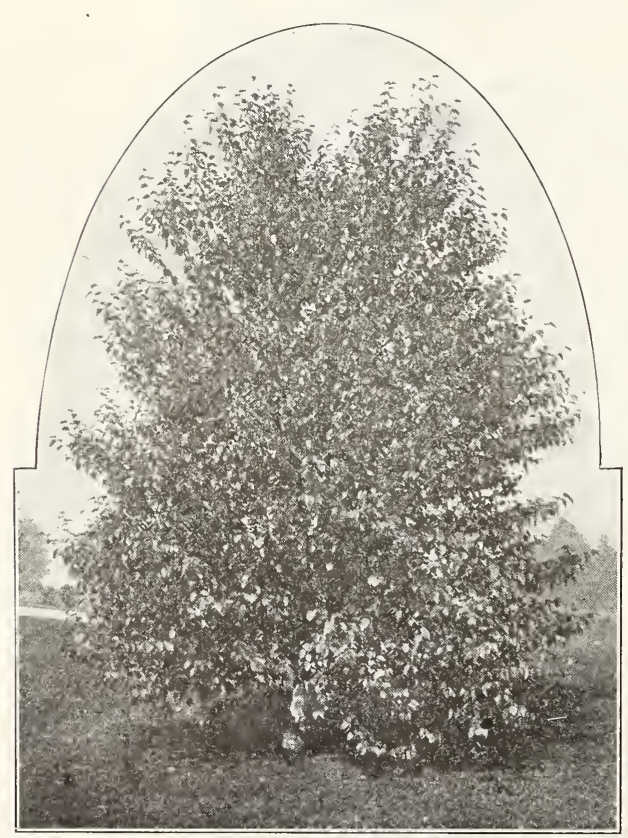

White Birch.

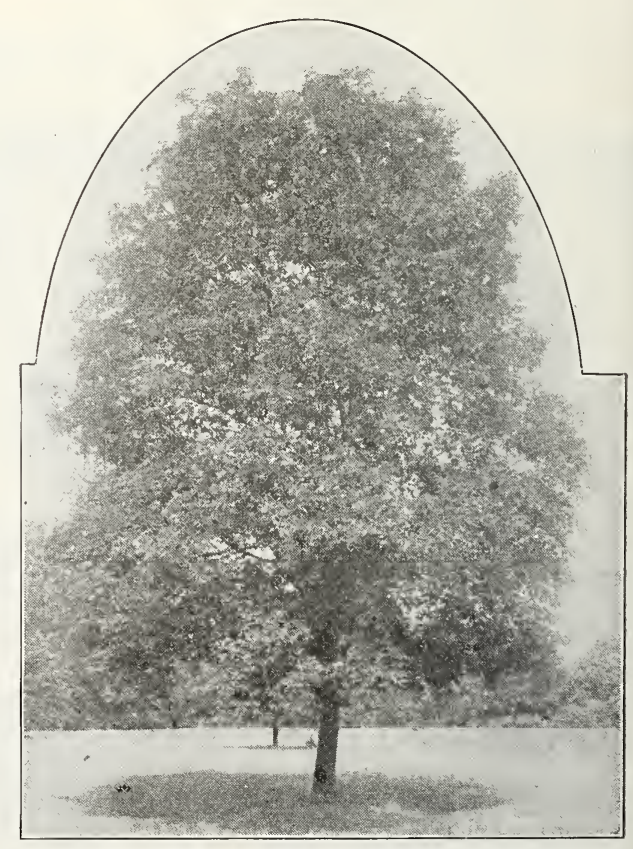

Ash. 


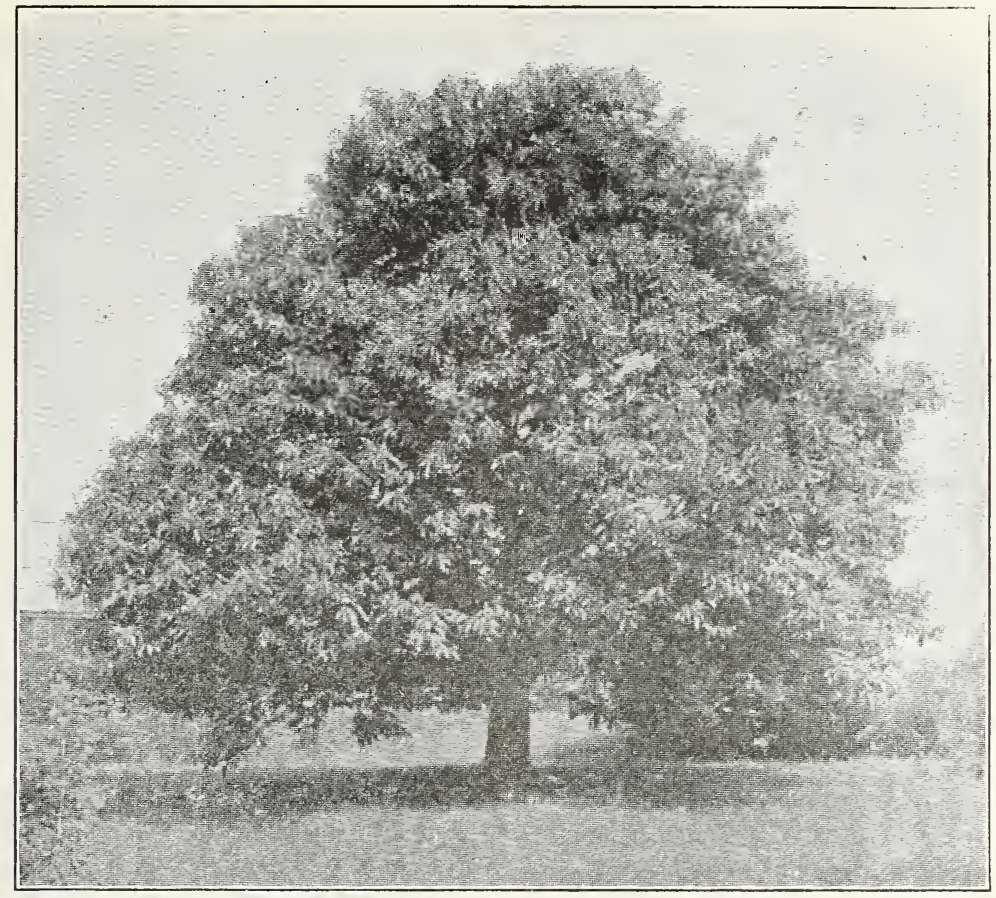

Hard or Sugar Maple.

Black or Yellow Locust. A large native tree of rapid growth, valuable for shade as well as quite ornamental. The yellowish white flowers are in long pendulous racemes and appear in June. Wood is very valuable for posts, growing quicker to a given size than any other hardwood tree. The timber is of very best quality and for posts outlasts, with a few exceptions, all other gorts. The Forestry Division of the Agricultural Department at Washington recommends the Black Locust for Timber Plantation for Oklahoma, Texas, New Mexico, Kansas, Nebraska and California.

Price of Black Locust Per 1 Per 10 Per 100 4 to 5 feet, nice transplanted

trees $\ldots \ldots \ldots \ldots \ldots \ldots \ldots \ldots . \ldots \ldots .10 \quad \$ 0.80 \quad \$ 6.00$

to 6 feet, nice transplanted

trees $\ldots \ldots \ldots \ldots \ldots \ldots \ldots, 15 \quad 1.40 \quad 13.00$

6 to 8 feet, nice transplanted $25 \quad 2.20 \quad 20.00$

Elm. American White. A noble native tree of large size, wide spreading head and graceful drooping branches Easy to transplant; a hardy grower. One of the best park and street trees. Hardy everywhere. I can furnish large White Elm trees, all well pruned, well rooted and with good tops, by the carload. Write for prices in large quantities.

Price of White Elm. Nice, well pruned trees: 3 to 4 feet..........\$ Per 1 Per 10 Per 100 4 to 4 feet..........\$0.07 \$0.60 \$ 4.00 4 to 5 feet........... $5,10 \quad .90 \quad \mathbf{7 . 0 0}$

6 to 8 feet. . . . . . .

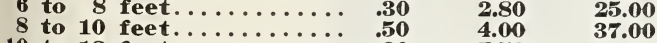

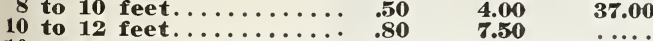

10 to 12 feet, 2 inches and over eal, very strong, each $\$ 1.25$.

Hackberry. Also called American Nettle Tree.
A rare native tree, with numerous slender branches which spread horizontally, and thick rough bark; apple-like foliage, but more pointed and a bright, shiny green. A very desirable tree for street planting. Perfectly hardy in Nebraska and the Northern states. Price of Hackberry. 4 to 5 feet, 25 cents each; 10 for $\$ 2.00 ; 5$ to 6 feet, 35 cents each; 10 for $\$ 3.00$.

Honey Locust. This is an ornamental native tree of more than ordinary value Its branches are spreading, forming a broad, rather loose head. The branches and trunk are covered with strong thorns. Its foliage is finely compound, giving a soft and beautiful appearance, light green in the spring and summer, turning to a clear yellow in the fall. Is of rapid growth, clear yellow in the fall. Is of rapid growth, hedge; its thorns make it almost impenetrable. I do not know of a better tree for western Kansas and western Nebraska. Price:

Per 1 Per 10 Per 100

3 to 4 feet, well pruned trees\$0.10 $\$ 0.75 \$ 5.00$

4 to 5 feet, well pruned trees $.13 \quad 1.00 \quad 8.00$

5 to 6 feet, well pruned trees $\mathbf{. 2 0} \quad \mathbf{1 . 6 0} \quad \mathbf{1 4 . 0 0}$

6 to 8 feet, well pruned trees $\mathbf{. 3 5} \quad \mathbf{3 . 0 0} \quad \mathbf{2 8 . 0 0}$

8 to 10 feet, well pruned trees $.65 \quad 6.00 \quad 50.00$

10 to 12 feet, well pruned trees $1.00 \quad 9.00 \quad 75.00$

Thornless Honey Locust. Same as above, except that it is entirely free of thorns and is therefore, much more suited for a lawn tree. Price. All well pruned trees, 3 to 4 feet, 15 cent: each, 10 for $\$ 100 ; 4$ to 5 feet, 20 cents each, 10 for $\$ 1.70 ; 5$ to 7 feet, 25 cents each, 10 for $\$ 2.40$ 7 to 8 feet, 45 cents each, 10 for $\$ 4.20 ; 8$ to 10 feet, 80 cents each, 10 for $\$ 7.50$.

Horse Chestnut. White flowering. A fine, large tree, of compact outline, dense green foliage. In June the tree bears in greatest profusion large panicles of white flowers, tinged with red. Very pretty for street or lawn. Price. 5 to 6 feet, 65 cents each, 10 for $\$ 6.00$. 
Maple, Soft or Silver. A native tree of very rapid growth. Hardy everywhere and easily transplanted. Leaves are finely cut bright green on upper and whitish on lower side. When you order a Silver Maple, you will get what is called a Soft Maple. When quick effect or shade is desired, the Soft Maple is one of the best trees to plant. Largely used for street or park planting. Price of Soft Maple:

Per 1 Per 10 Per 100

3 to 4 feet, well pruned trees\$0.10 $\$ 0.60$ \$ 4.00 4 to 5 feet, well pruned trees $.12 \quad .85 \quad 6.00$

5 to 6 feet, well pruned trees $\mathbf{. 1 5} \mathbf{1 . 3 5} \mathbf{1 0 . 0 0}$

6 to 8 feet, well pruned trees $\mathbf{. 3 0} \mathbf{2 . 7 5} \mathbf{2 5 . 0 0}$ 8 to 10 feet, well pruned trees $\mathbf{. 6 0} \mathbf{5 . 0 0} \mathbf{4 5 . 0 0}$ 10 to 12 feet, nice well pruned trees, $\$ 1.00$ each.

Maple, Sugar or Hard. A popular American tree of pyramidal form. The foliage is large and handsome and of rich, pleasing green, turning to orange yellow and red in autumn. Its upright habit of growth, dense shade and adaptability to different soils has rendered it one of the most extensively used. Valuable for sugar and timber. Price: 5 to 6 feet trees, 45 cents each, 10 for $\$ 4.00 ; 6$ to 8 feet, 75 cents each, 10 for $\$ 7.00 ; 8$ to 10 feet, $\$ 1.00$ each.

Linden or Basswood. A very pyramidal tree with large leaves and fragrant flowers. A valuable tree for street or lawn planting, developing into beautiful specimens. Extensively planted for ornamental purposes and for bee culture. Rapid growth, not particular as to soil, and perfectly hardy. Price: 4 to 5 feet trees, 25 cents each, 10 for $\$ 2.00 ; 5$ to 6 feet trees, 35 cents each, 10 for $\$ 3.00$.

Carolina Poplar. One of the most rapid growing trees, with large, handsome, glossy, deep green leaves. Succeeds everywhere; especially adapted to cities, where it makes unusually fast growth and resists smoke and gas. Pyramidal in form, making a spreading head and dense shade when properly trimmed. It is unexcelled for quick growth and effect; makes a splendid windbreak or screen. It is used in larger numbers for street planting than any other tree. A

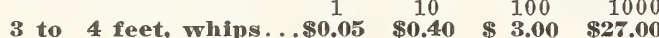

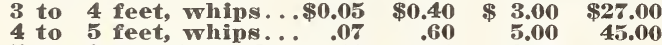
5 to 6 feet, branched $\mathbf{. 1 0} \quad \mathbf{. 9 0} \quad \mathbf{8 . 0 0}$ 6 to 8 feet, branched $\begin{array}{rrrr}.20 & \mathbf{1 . 7 5} & 15.00 & \ldots\end{array}$

8 to 10 feet, branched $.40 \quad 3.50 \quad 28.00 \quad \ldots$

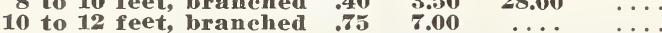

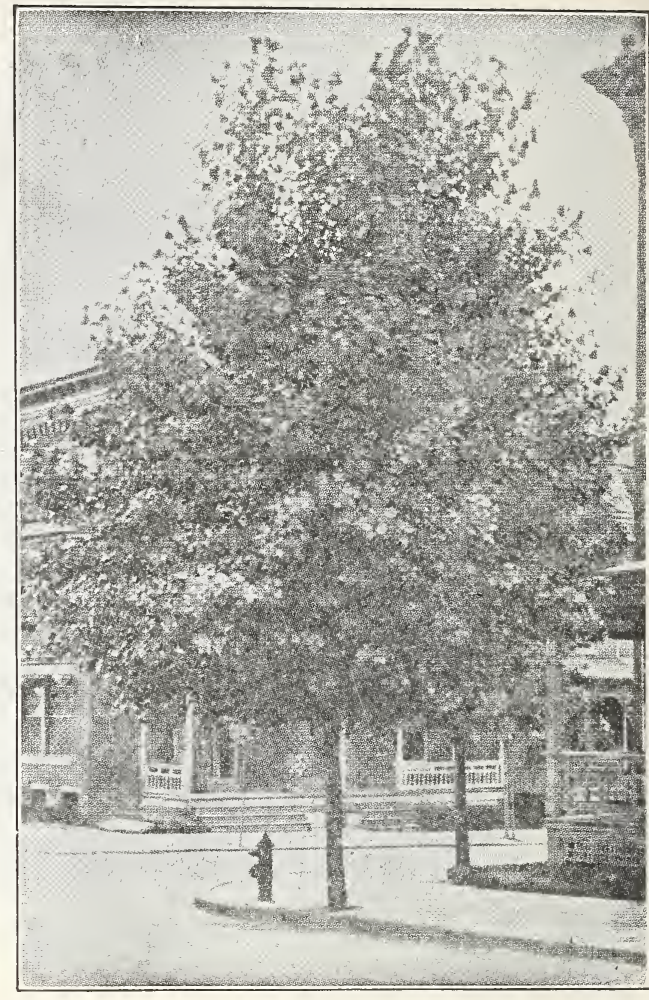

CAROLINA POPLAR.

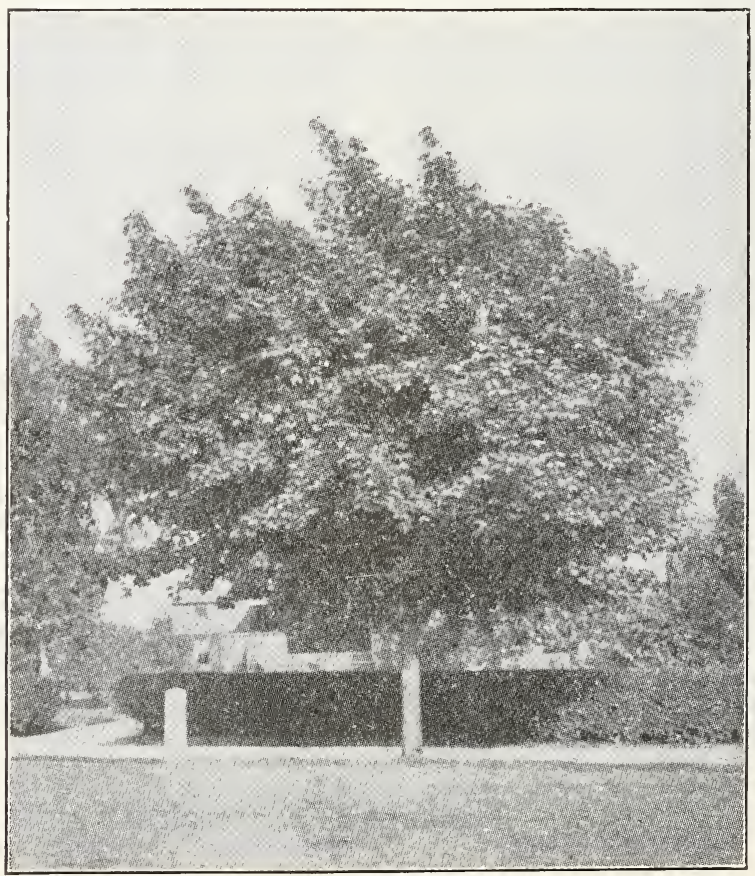


Norway Poplar. Sudden Saw Log. A very distinct tree in habit of growing and making a straight, upright, somewhat pyramidal head. The foliage is large, thickly borne, bright and glossy. It grows rapidly in almost every soil, and yet it possesses strength and durability superior to most of the other poplars, as it withstands the effect of smoke and dust much better. These same elements make the Norway Poplar a superior tree for planting in the shelter of a superiantations. It is claimed that this tree will mature a log two feet in diamater in sixteen years, making quicker growth than any other tree adapted for the Middle or Northern states.

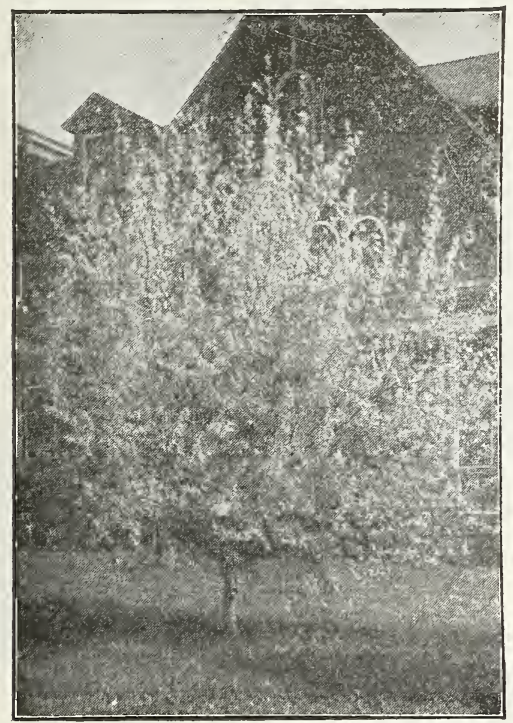

Russian Olive

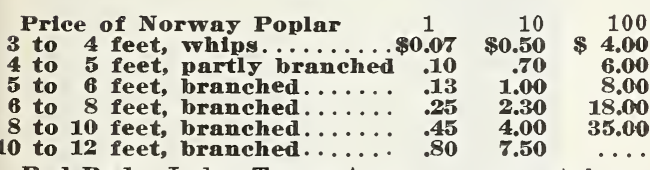

Red Bud. Judas Tree. A very ornamental native tree of medium size, with perfect heartshaped leaves and hardy even in Canada. Blooms early in the spring, before the leaves appear, covering the branches with small reddish-purple flowers. Price: 5 to 6 feet trees, 30 cents each, 10 for $\$ 2.75 ; 4$ to 5 feet, 25 cents each, 10 to $\$ 2.25$.

Russian olive. A beautiful lawn tree, with spreading top; nearly black shining bark, and silvery-white long, narrow foliage. The small yellow blossoms have a wonderful appearance. The exquisite perfumes are carried long distances in the air. Fine if planted in a group with green leaved trees, among shrubbery, or as a lawn tree. Hardy as far north as Canada. It deserves a place in every park or garden. Should be much more largely planted. Can also be used as a hedge or screen, as it stands pruning or shearing well. See under plants for hedges and screens.

Price of Russian olive: Per 1 Per 10 Per 100 4 to 5 feet, nice trees.........30 $2.80 \quad 25.00$ 5 to 6 feet, nice trees ..........35 $3.20 \quad \ldots$

Tulip Tree. (Whitewood.) One of the grandest of our native trees; of tall pyramidal habit, with broad, glossy fiddle-shaped leaves and beautiful, tulip-like flowers; allied to the Magnolia. 5 to 6 feet trees, 35 cents each, 10 for $\$ 3.00$.

Sycamore, American. Noble, upright growing tree, with spacious head and large, deep green foliage. A free grower and very desirable for

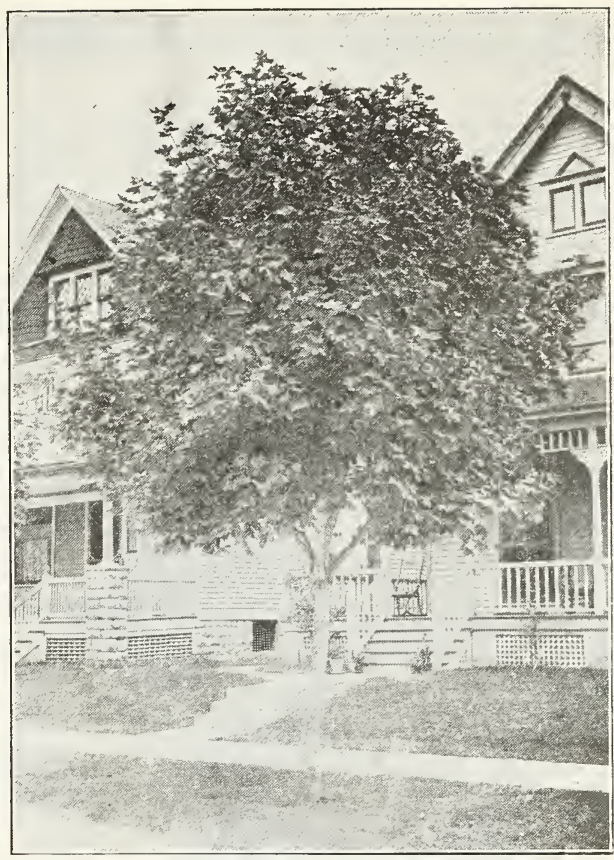

Sycamore

park or street planting. It is not hardy though, north of here, and I cannot recommend it even for the middle of Nebraska.

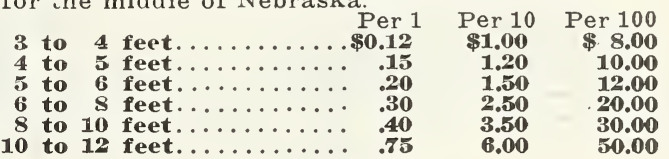

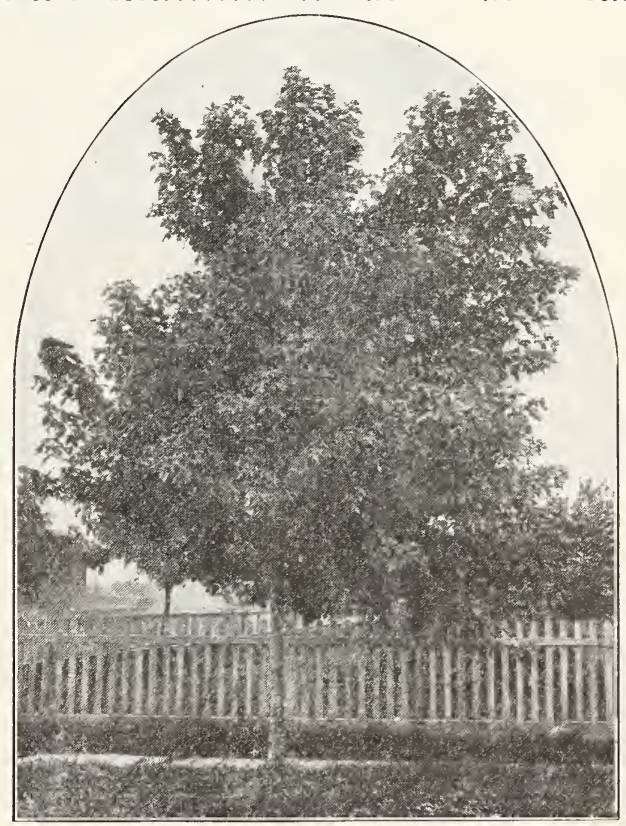

Silver Maple 


\section{Evergreens}

Hardy coniferous Evergreens are particularly valuable for use in all classes of ornamental planting in as much as they preserve their graceful foliage and rich coloring throughout the summer and winter, adding much to the charm of the landscape during that period when deciduous trees and shrubs are without foliage. The following Evergreens are very hardy and particularly adapted to our Western climate. On account of the shade the frost remains long in the ground among Evergreens. For this reason they cannot be shipped as early as other trees. We usually commence to ship them from April 1st to 15 th.

Arbor Vitae, American. A well-known Evergreen of great value; it forms an upright, conical tree of medium size and is, all things considered, the finest Evergreen for screens, being hardy, and easily transplanted. It grows rapidly and with little care, and soon forms a beautiful hedge, very dense and perfectly impervious to the sight. Are widely planted throughout the United States.

Price of Arbor Vitae: Per 1 .05
.25
.35

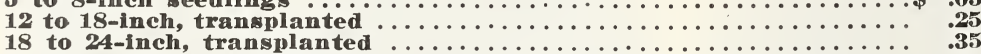

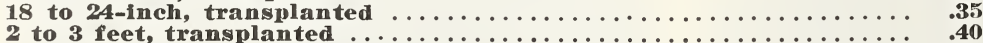
$\begin{array}{rrr}\text { Per } 10 & \text { Per } 100 & \text { Per } 1,000 \\ \$ \mathbf{\$ 4 0} & \mathbf{\$ 1 . 3 0} & \mathbf{\$ 1 2 . 0 0} \\ \mathbf{2 . 2 0} & \mathbf{1 8 . 0 0} & \ldots \ldots \\ \mathbf{3 . 2 0} & \mathbf{2 8 . 0 0} & \ldots \ldots \\ \mathbf{3 . 7 0} & \mathbf{3 4 . 0 0} & \ldots \ldots\end{array}$

Blue Spruce. The Blue Spruce is the most beautiful of all conifers. Its silver foliage, glistening in the sunlight, makes it surpass in beauty any other Evergreen. It is very hardy; a good grower, will withstand severe winters and excessive moisture, and is very easily transplanted. The Blue spruce has no equal for lawn and cemetery use.

Price of Blue Spruce: $\quad$ Per 1 Per 10 Per 100 Per 1,000 4 to $6-i n c h$, as they run in

nursery row ............... $.05 \quad \$ .40 \quad \$ 3.00 \quad \$ 25.00$

10 to 12 -inch, transplanted, not $\begin{array}{lllll} & & & & \\ & & \end{array}$

Grafted Blue Spruce, fine colors, transplanted, and shipped with ball of earth attached. 1-foot trees $\$ 1.00$ each; 2 -foot trees $\$ 2.50$ each.

Norway spruce. A lofty tree, of perfect pyramidal form, remarkably elegant and rich, and as it gets age, has fine pendulous branches; it is exceedingly picturesque and beautiful. One of the best evergreen hedges and windbreaks.

Price Norway spruce:

8 to 10-inch seedlings $\ldots \ldots \ldots \ldots \ldots \ldots \ldots \ldots$ Per 1

12 to 18 -inch, transplanted $\ldots \ldots \ldots \ldots \ldots \ldots, \mathbf{. 1 5}$

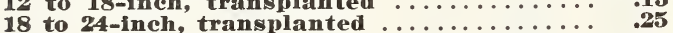

2 to $\mathbf{3 - f o o t}$, transplanted $\ldots \ldots \ldots \ldots \ldots \ldots \ldots \ldots$

$\begin{array}{rr}\text { Per } 10 & \text { Per } 100 \\ \$ \mathbf{. 5 0} & \mathbf{\$ 3 . 0 0} \\ \mathbf{1 . 3 0} & \mathbf{1 2 . 0 0} \\ \mathbf{2 . 0 0} & \mathbf{1 8 . 0 0} \\ \mathbf{2 . 8 0} & \mathbf{2 5 . 0 0}\end{array}$

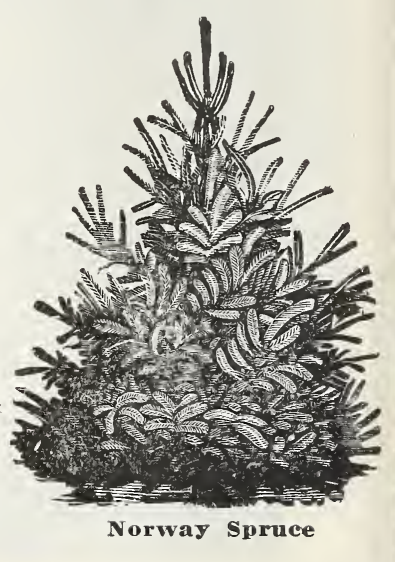

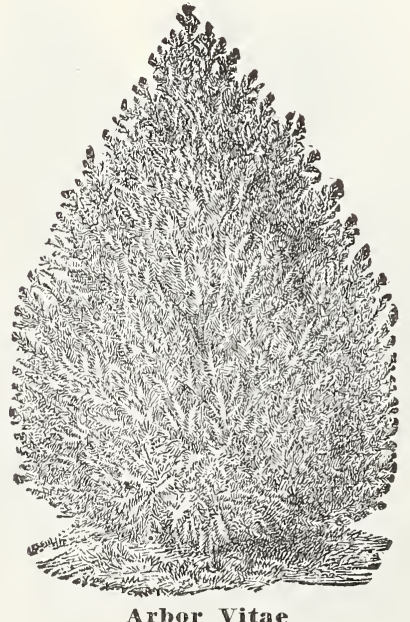

Arbor Vitane

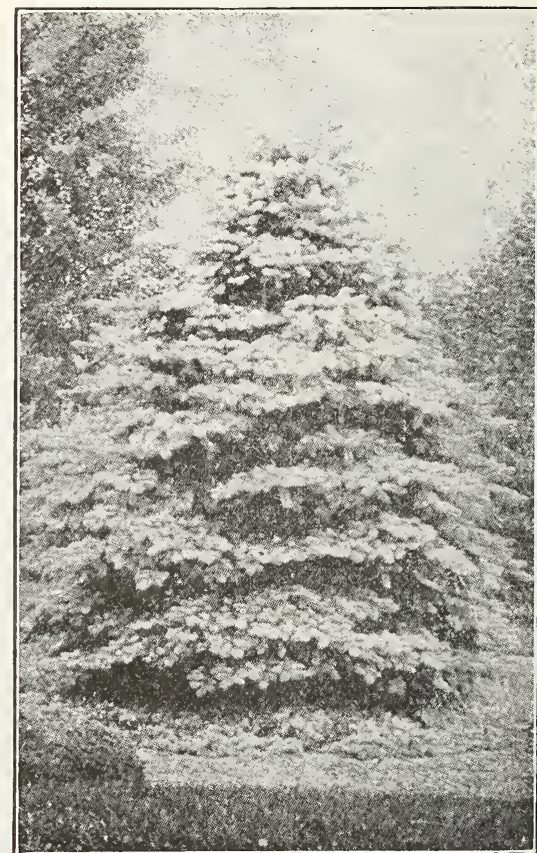

Blue Spruce 

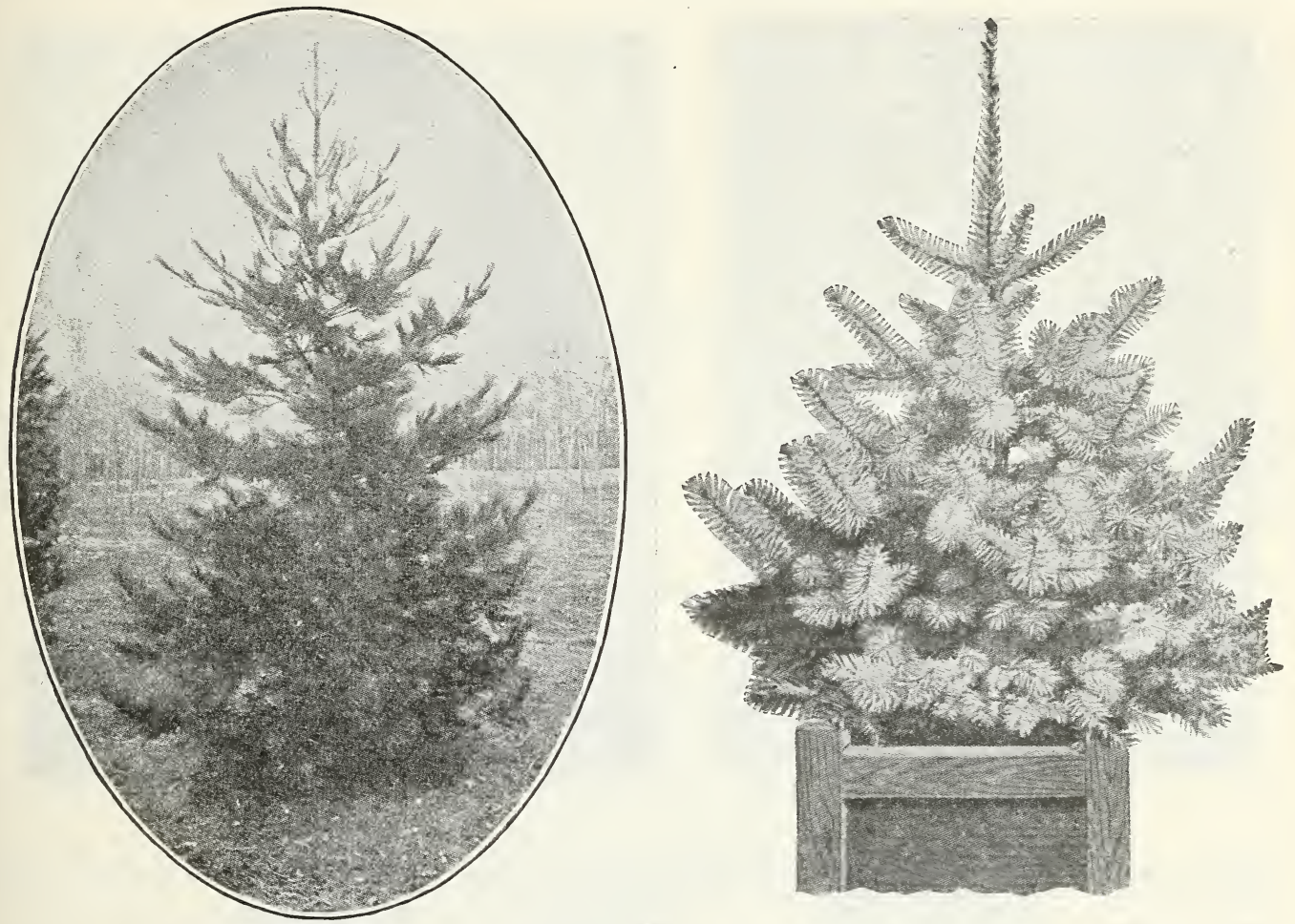

White Pine

Austrian Pine. The Austrian or Black Pine is a stout branched tree of rapid growth; branches rather long in proportion to the trunk than most pines. The elegant whorls of branches are densely clothed with deep, blackish green follage. It is one of the best pines for forming screen. Perfectly hardy and thrives well in dry soil and upon high, bleak hills.

Price of Austrian Pine:

\begin{tabular}{|c|c|c|c|}
\hline $\begin{array}{l}\text { to } 10 \text {-inch seedlings ... } \\
12 \text { to } 18 \text {-inch, transplanted } \\
18 \text { to } 24 \text {-inch, transplanted } \\
2 \text { to } 3 \text { feet, transplanted.. }\end{array}$ & $\begin{array}{r}\text { Per } 10 \\
\mathbf{\$} . \mathbf{3 5} \\
\mathbf{2 . 8 0} \\
\mathbf{3 . 2 0} \\
\mathbf{3 . 7 0}\end{array}$ & $\begin{array}{r}\text { Per } 100 \\
\$ \underset{2.50}{22.00} \\
\mathbf{2 2 . 0 0} \\
\mathbf{3 0 . 0 0} \\
\mathbf{3 5 . 0 0}\end{array}$ & 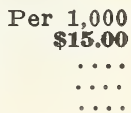 \\
\hline
\end{tabular}

Scotch Pine. (Pinus Sylvestris.) A dense growing, broad, pyramidal tree with stout, erect shoots and pleasing silver-green foliage. One of the best ornamental forest trees. Grows luxuriantly in most soils.

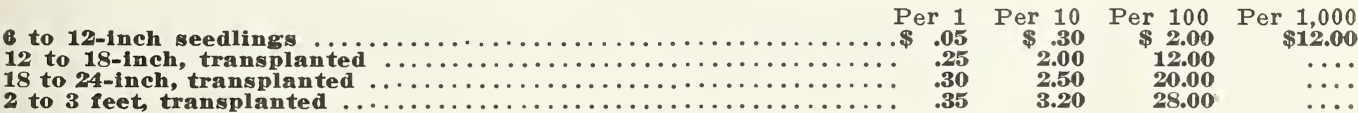

White Pine. (P. Strobus.) The most ornamental of all our native Pines. A tall and very beaut1ful tree with regular whorls of horizontal branches, forming a pyramidal crown. Foliage light, dellcate sllvery green: will grow in the poorest of sandy soils; a long-lived tree and rapid grower. The valuable pine with a wide range of usefulness and adaptability, both for commercial and ornamental purposes.

Price of White Pine: Per 1

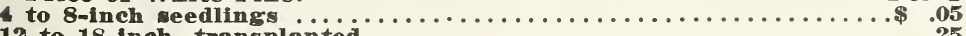

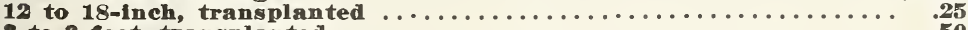

\$..30

Per $\underset{\$ \mathbf{2 . 0 0}}{100}$

Per 1,000

2 to 3 reet, transplanted

Jack Pine. (Pinus Divaricata.) The most northern of all American pines. Extremely hardy and vigorous, withstanding long droughts and hot, dry winds. Of rather irregular growth. Foliage bright green; needles short and stiff.

Price of Jack Pine:

6 to 12 -inch seedlings

Per 1

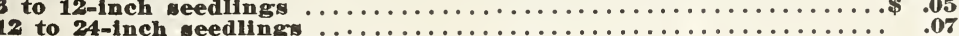

18 to $24-1 n c h$, traneplanted

2 to 3 feet, transplanted.

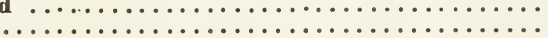

.07

$\begin{array}{rr}\text { Per } & 10 \\ \$ & .30 \\ .50 \\ \mathbf{1 . 8 0}\end{array}$

Per 100

$\$ \begin{array}{r}\mathbf{1 . 6 0} \\ \mathbf{3 . 0 0}\end{array}$

Per 1,000

$\mathbf{1 7 . 0 0} \quad \mathbf{2 0 . 0 0}$

... $\quad \ldots$ 


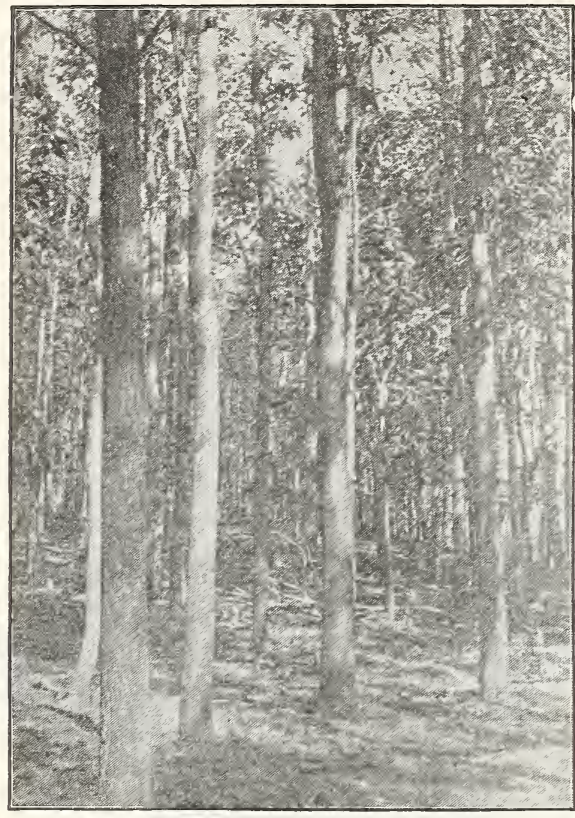

Catalpa

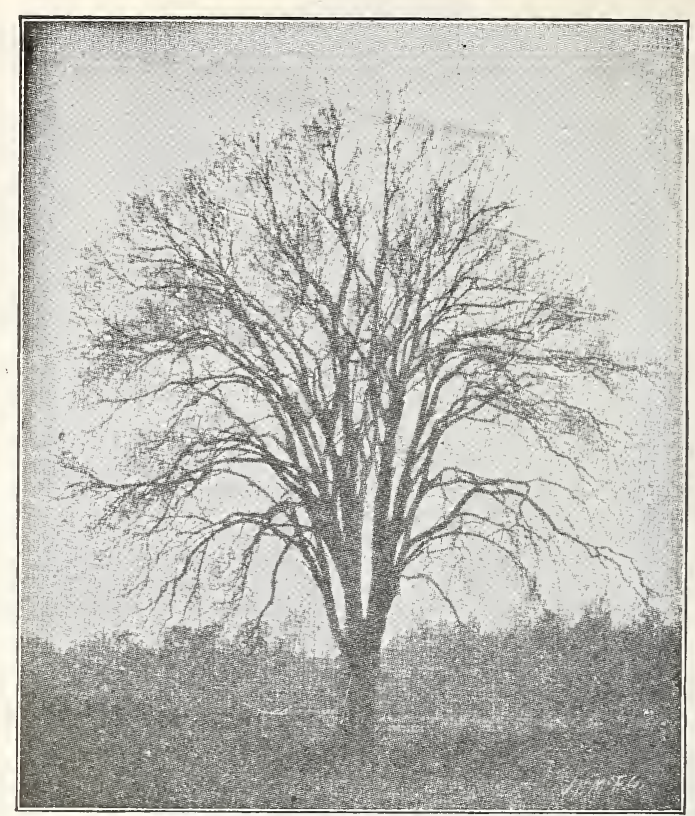

Elm

Red Cedar. One of the best evergreens either for ornamental planting or for windbreaks. It can also be planted for hedges, and looks well sheared.

Price of Red Cedar:

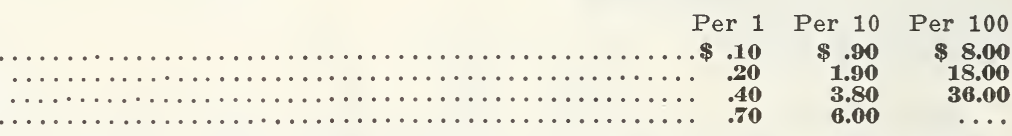

6 to 8 -inch seedling

10 to 18-inch, transplanted

18 to 24-inch, transplanted

2 to 3 feet, transplanted.

Irish Juniper. (Juniperus.) Forms a dense, close, columnar tree, fifteen to twenty feet in height. The branches are regular, very compact and densely covered with rich, deep green foliage. A pretty little tree and very useful in formal work. Succeeds best in well drained soils.

Price of Irish Juniper: 8 to 10-inch, transplanted

12 to 18 -inch, transplanted.

(1)

2 to 3 feet, transplanted, with ball of dirt....................8

$\begin{array}{rr}\text { Per } 10 & \text { Per } 100 \\ \$ 1.80 & \$ 16.00 \\ \mathbf{3 . 8 0} & \ldots \ldots \\ \cdots & \ldots .\end{array}$

\section{Forest Tree Seedlings}

We have millions of them, principally Black and Honey Locust, Catalpa and Mulberry. Lumber and posts are becoming more expensive every year, and people could save a great deal of this expense by planting some of the quick-growing forest trees. Nearly every farm has some waste land that could be used for this purpose.

Ash, 6 to 10 inches

Per 100 Per 1,000

Ash, 10 to 15 inches

$\$ .25$

Ash, 15 to 30 inches

Box Elder, 6 to 10 inches

Box Elder, 10 to 15 inches

Box Flder, 15 to 20 inches

Black Locust, 5 to 8 inches

Black Locust, 8 to 12 inches

Black Locust, 18 to 24 inches

Black Locust, 2 to 3 feet

Honey Locust, 6 to 12 inches

Honey Locust, 12 to 18 inches

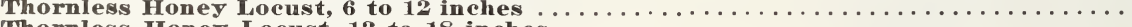

Soft Maple, 6 to 12 inches

Soft Maple, 12 to 18 inches

Soft Maple, 18 to 24 inches.

Sugar Maple, 12 to 18 inches

White

white Elm, 18 to 24 inches

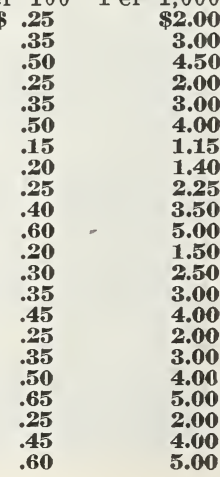


Catalpa Speciosa, 6 to 12 inches

Catalpa Speciosa, 12 to 18 inches .

Catalpa Speciosa, 18 to 24 inches

Catalpa Speciosa, 2 to 3 feet

Cottonwood, 10 to 15 inches ......

American Linden, 12 to 18 inches

Sycamore, 12 to 18 inches

Apple Seedlings, No. 1

Apple Seedlings, No. 2

FAIRBURY,

Apple Seedlings, No. 3

\section{Cuttings}

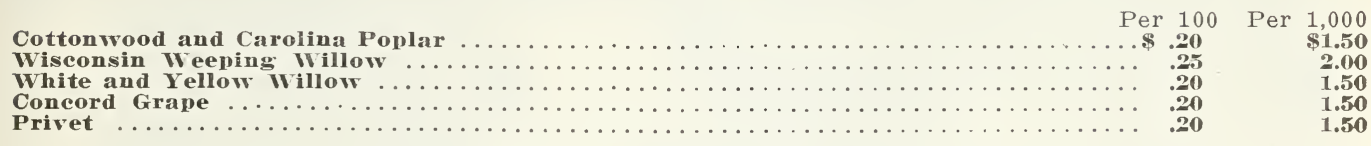

\section{Hedge Plants}

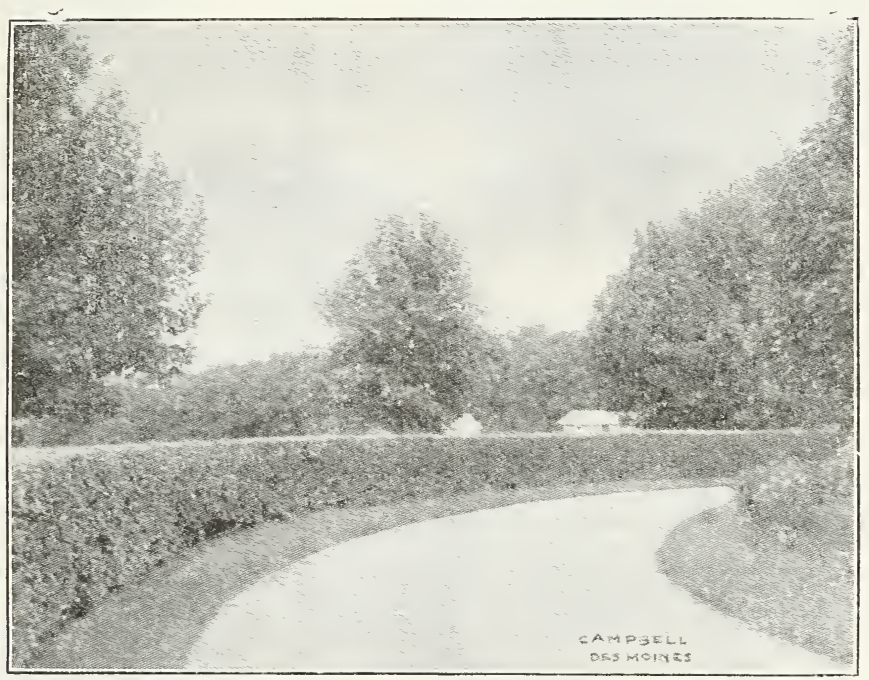

Amoor Privet

Amoor River Privet. Hardy. Foliage glossy green and holds its color well almost the entire year. Will stand shearing to any extent. Where the California Privet is not hardy, the Amoor River should be planted. It stood the freezing of last winter without injury $n$ the vicinity of Chicago.

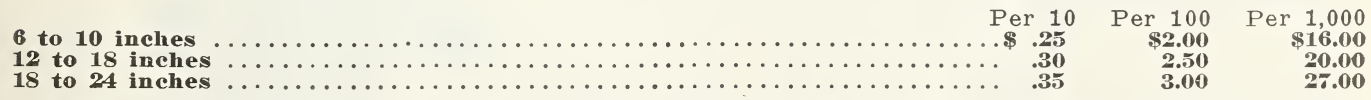

Hardy Privet. This plant will stand as much cold as the Amoor River variety, but does not grow quite so rapidly. Leaves are more nearly like the California Privet and will remain on until Christmas.

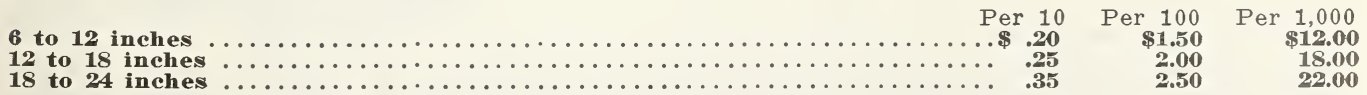

Osage Orange. (Bois d'Arc.) A valuable tree for its timber, posts of this wood being almost Osage Orange. (Bois d'Arc.) A valuable tree for its timber, posts of this wood being almost
indestructible. It should be planted exclusively south of here. It is not hardy north of Nebraska. Stands pruning well and makes a beautiful and effective hedge.

6 to 12 inches

Per 100

12 to 18 inches.

Per 100

18 to 24 inches

Per 1,000 $\$ 1.50$ 2.00 $\mathbf{3 . 0 0}$ 
Common Buckthorn. A hardy shrub, extensively used in England and the continent for live hedges. Is covered with pretty white blossoms in the spring and red berries in the fall. The Buckthorn does well in Nebraska and is perfectly hardy.

Price-For 12 to 18 -inch plants, 5 cents each; 40 cents per $10 ; \$ 3.00$ per $100 ; \$ 25.00$ per 1,000 .

Russian Mulberry. This tree makes one of the finest hedges. It is perfectly hardy, will grow as far north as Minnesota, will stand drouth well and can be sheared in any shape desired.

Per 100

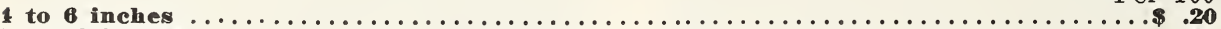

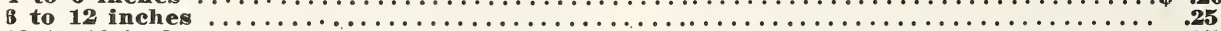

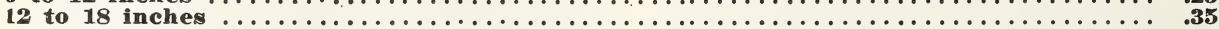

Per $\begin{aligned} & 1,000 \\ & \$ 1.00\end{aligned}$

$\mathbf{2 . 0 0}$

Barberry Thunbergi. Japanese Barberry. Invaluable little shrub that fits in with almost every planting. Grows about anywhere, handsome foliage of bright green, oval leaves, that turn to most brilliant shades of orange and red in the fall. Slender, graceful branches, protected by thorns, are lined with little scarlet berries of great attractiveness from early autumn well into winter. Very valuable for a hedge.

Price-18 inches, per $10 \$ 1.20$; per $100 \$ 10.00$.

\section{Seeds}

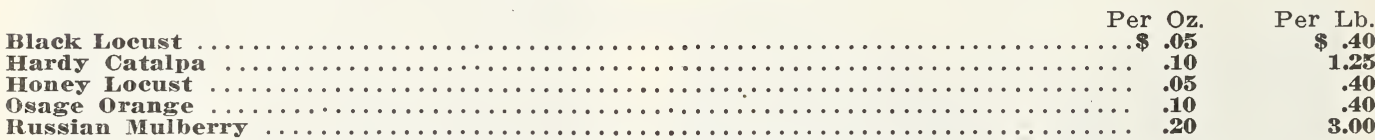

If you want seeds sent by mail, add 8 cents per pound to price.

\section{Apple Grafts}

Send in your orders for grafts early. The first of March we commence to plant and after that date our list of varieties is broken. Can furnish any variety listed in this catalog except Seedless.

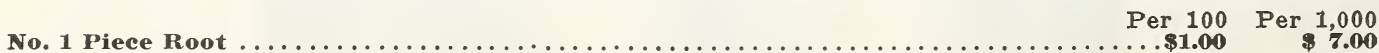

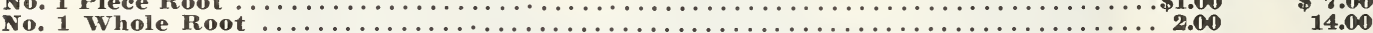

\section{Nut Trees}

American Sweet Chestnut. The nuts of this tree form quite an item in our commerce. They are sweet and delicately flavored. This Chestnut is also a grand timber and ornamental shade tree, gpreading in mid-summer, billowy masses of creamy, fragrant catkins above its large, deep green leaves, making a most beautiful specimen on thelawn. Does well in Nebraska. Chestnuts do we 11 on medium thin and sandy land, requiring nopruning and little or no cultivation. The timber is very durable and possesses a fine grain for oil finish.

Per 1 Per 10 Per 100

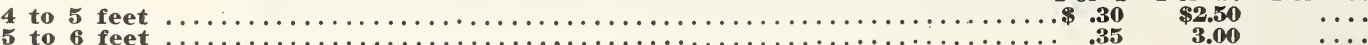

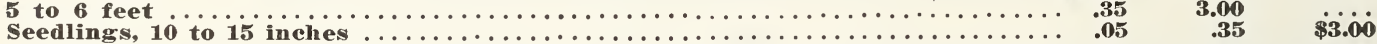

English or Persian Walnut. A fine, lofty growing tree, with handsome spreading head; produces large crops of thin shelled, delicious nuts that are always in demand at good prices. The fruit in green state is highly esteemed for pickling. Unlike the native walnuts, the nut drops from its green state is highly esteemed for pickling. Unlike the native walnuts, the nut drops from its
shucks when ripe as readily as those of hickory. The orchards of California and the South are yielding handsome profits, and still the nuts are imported in great quantities. Not hardy enough for general culture North.

6 to 12 inches

$$
\text { Per } 1 \text { Per } 10 \text { Per } 100
$$

Butternut or White Walnut. The nuts are large, long, oily and nutritious. The lofty, spreading tree is one of our finest natives, valued for its tropical appearance and beautiful wood, as well as for its nuts. Does well in Nebraska and as far north as Dakota.

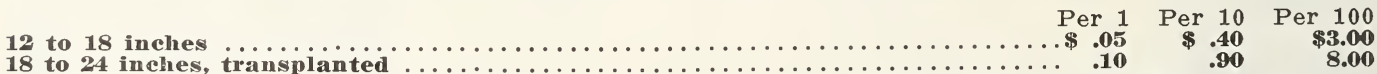

Black Walnut. A native of Nebraska. Of large size and majestic form, with beautiful foliage. Grows best on low enters largely into the manufacture of furniture and cabinet work, and brings the very highest price in the market. Tree is a fairly rapid grower. The large, oily nuts are of fine flavor and always marketable at a fair price.

6 to 12 inches

Per 1 Per 10

12 to 18 inches

5 to 6 feet

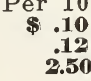

$\begin{array}{rr}\text { Per } 100 & \text { Per } \begin{array}{r}1,000 \\ \mathbf{9 . 7 0}\end{array} \\ \mathbf{9 6 . 0 0} \\ \ldots \ldots & \mathbf{8 . 0 0} \\ \ldots & \ldots \ldots\end{array}$ 


\section{Plant Department}

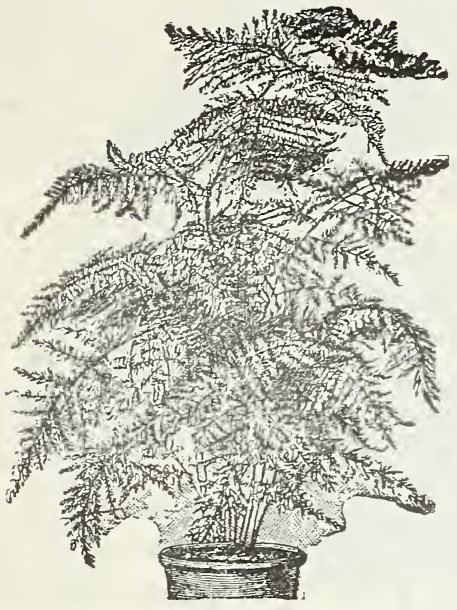

Asparagus Plumosus.

.Asparagus Plumosus or Asparagus Fern. It is a most elegant plant with smooth stems and has very graceful, arching, filmy foliage; it rivals the delicate beauty of the Maiden Hair Fern. The cut sprays of this variety endure for a long time. It is indispensable as a green in floral decorations. Remarkably fine for pot culture, as it is very ornamental. By mail 10 cents each, by express, large plants, 20 cents and up.

Asparagus Sprengeri. One of the best known plants introduced in years. This plant is exceedingly useful and ornamental, as a pot plant.

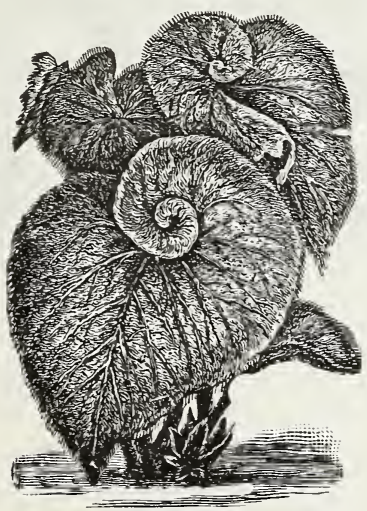

Rex Begonia.

In a hanging basket it droops gracefully with branches that are sometimes 4 to 5 feet in length; of a rich shade of green. The fronds retain their freshness for weeks after being cut.

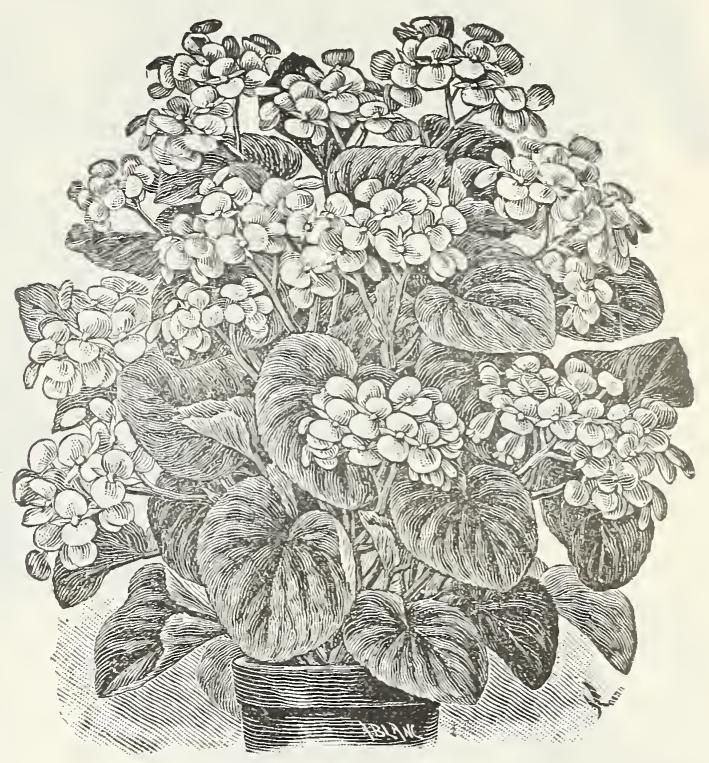

Begonia Semperfiorens.

Especially useful for planting in ferneries or in suspended baskets. It is fine for house decorations as it withstands dry atmosphere. By mail 10 cents each, by express, large plants, 20 cents and up.

Ageratum. A very popular bedding plant, extensively used as edging for beds and also for massing. Price postpaid, 7 cents each, per dozen 60 cents.

Rex Begonias. Well known as very decorative plants for the house. They do not require sun or even strong light and so can be used where flowers or plants will not thrive. They should be given a nice, shady situation, and then soil should be light and porous, composed of rich loam, sand and leaf mold. The Rex varieties are very effective as pot plants. Care should be taken to keep the foliage free from dust Occasionally the plants may be showered, but should not be exposed to the sun until the leaves are perfectly dry. We have five of the best. varieties. Price 20 cents each.

Begonia Semperflorens takes rank as bedding plants with Geraniums and Coleus, doing equally well in full sunlight, and surpassing both in positions partially or wholly in shade. They are of sturdy growth, growing about 1 foot high and forming dense bushes, which, from May until frost, are completely hidden with flowers. As pot plants for winter flowering they are superb, remaining a sheet of bloom throughout the entire year. Colors pink and red. Price 10 cents each postpaid. 


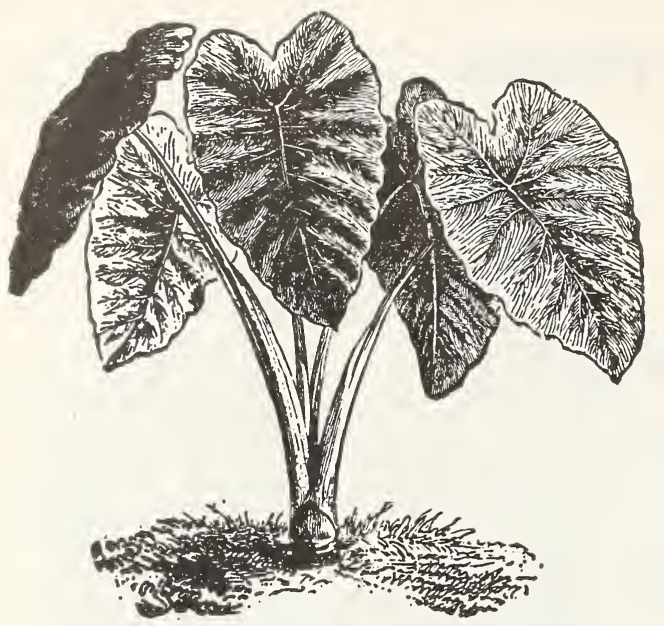

Caladium Esculentum.

Caladium Esculentum (Elephant's Ear). For obtaining tropical effects in lawns and gardens planting this beautiful plant takes a promdens planting this beautiful plant takes a prom-
inent place. Should have plenty of water and good, rich soil. When at its best, stands six to seven feet high, with bright green leaves three to four feet long and two and one-half feet wide. Large bulbs 20 cents each, 6 for $\$ 1.00$ postpaid.

\section{Callas}

One of the most satisfactory summer flowering bulbs when planted in the open ground and equally good as a pot plant for winter blooming, when planted in the fall, the foliage is a dark green, flowers pure white. Large bulbs 20 cents each; 6 for $\$ 1.00$ postpaid.

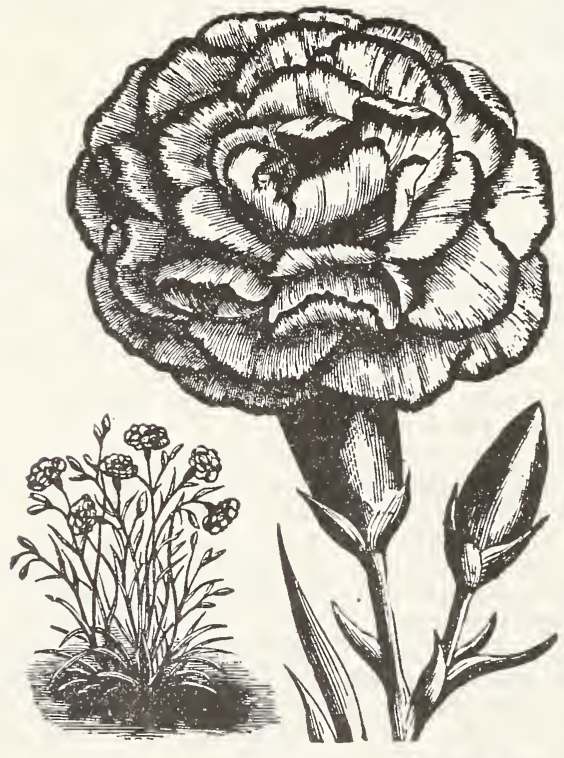

Carnation.

\section{Carnations}

The Carnation is the most popular flower grown by florists, as they are much desired for house decoration and personal adornment. The new mammoth varieties are especially attractive. They are beautiful in coloring, perfect in form and shape, and some of them three and one-half inches across. We will list the following varieties as best for house culture. Plant in open ground in May. Colors white, light ping, dark pink, red, dark red. Price 15 cents each, 6 for 50 cents postpaid.

\section{Cannas}

One of the most popular of bedding plants with their green and bronze foliage and bright flowers; we grow six of the best varieties. Price 10 cents each, one dozen $\$ 1.00$, for dry bulbs. Bulbs which have been started to grow in the green house, 15 cents each, 8 for $\$ 1.00$ postpaid.

King Humbert. Four to five feet. Giant flowered, orange scarlet, bronze leaf. The flowers are very large and very free blooming. The handsome leathery foliage is of strong habit.

Florence Vaughn. Five feet. Green foliage; flowers are a rich golden yellow, thickly dotted brightest red.

Mad. Crozy. Three and one-half feet. Green foliage. Flowers vermillion with gold border.

Burbank. Five feet. Green foliage; flowers are very large in size; a rich canary-yellow with crimson spots.

Crimson Bedder. Bright crimson scarlet.

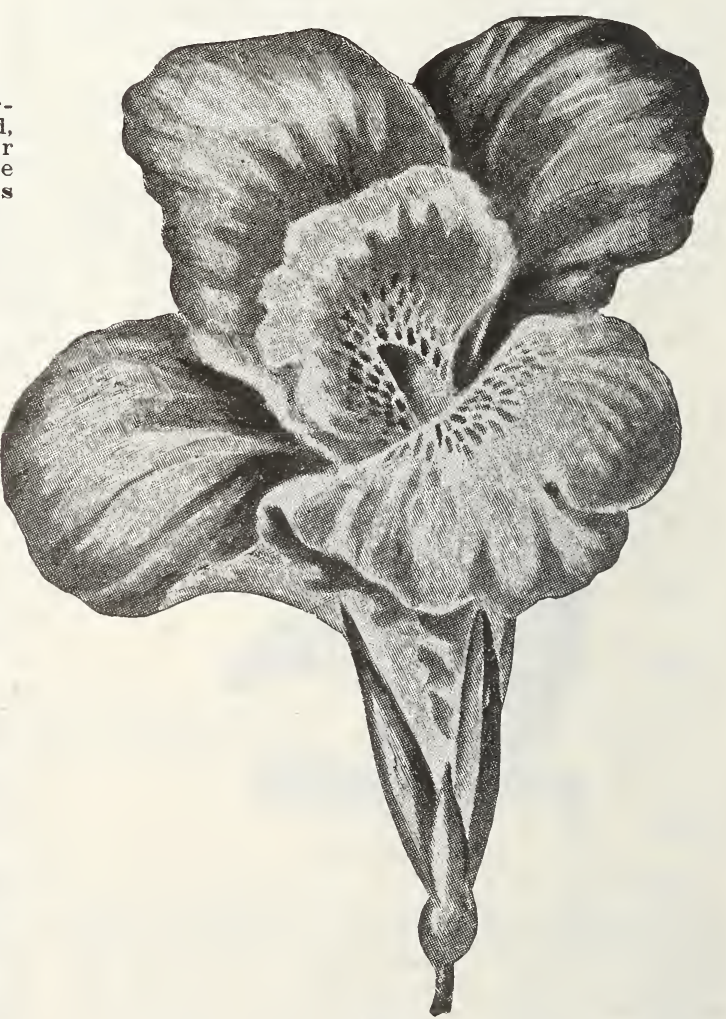

Canna. 


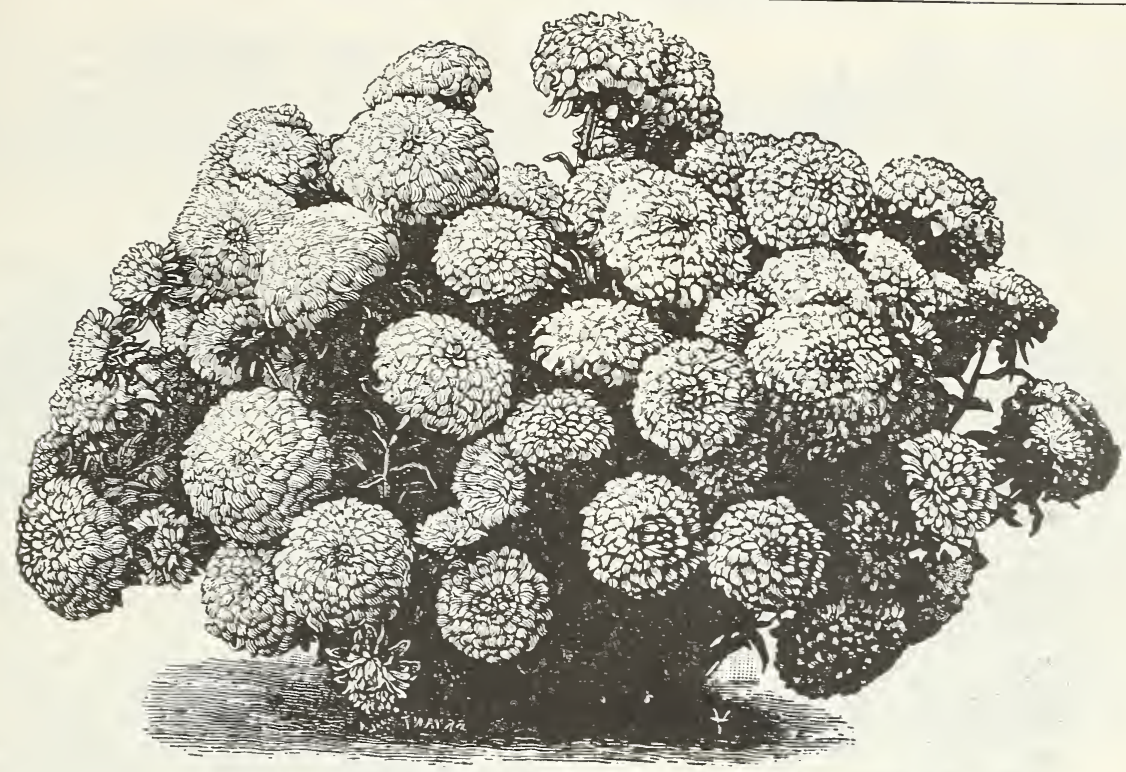

\section{Chrysanthemums}

We grow ten of the best varieties of yellow, white and pink "Mums." Plant in open ground in May. Price 10 cents each, $\$ 1.00$ per dozen postpaid.

Colors, white, yellow and pink.
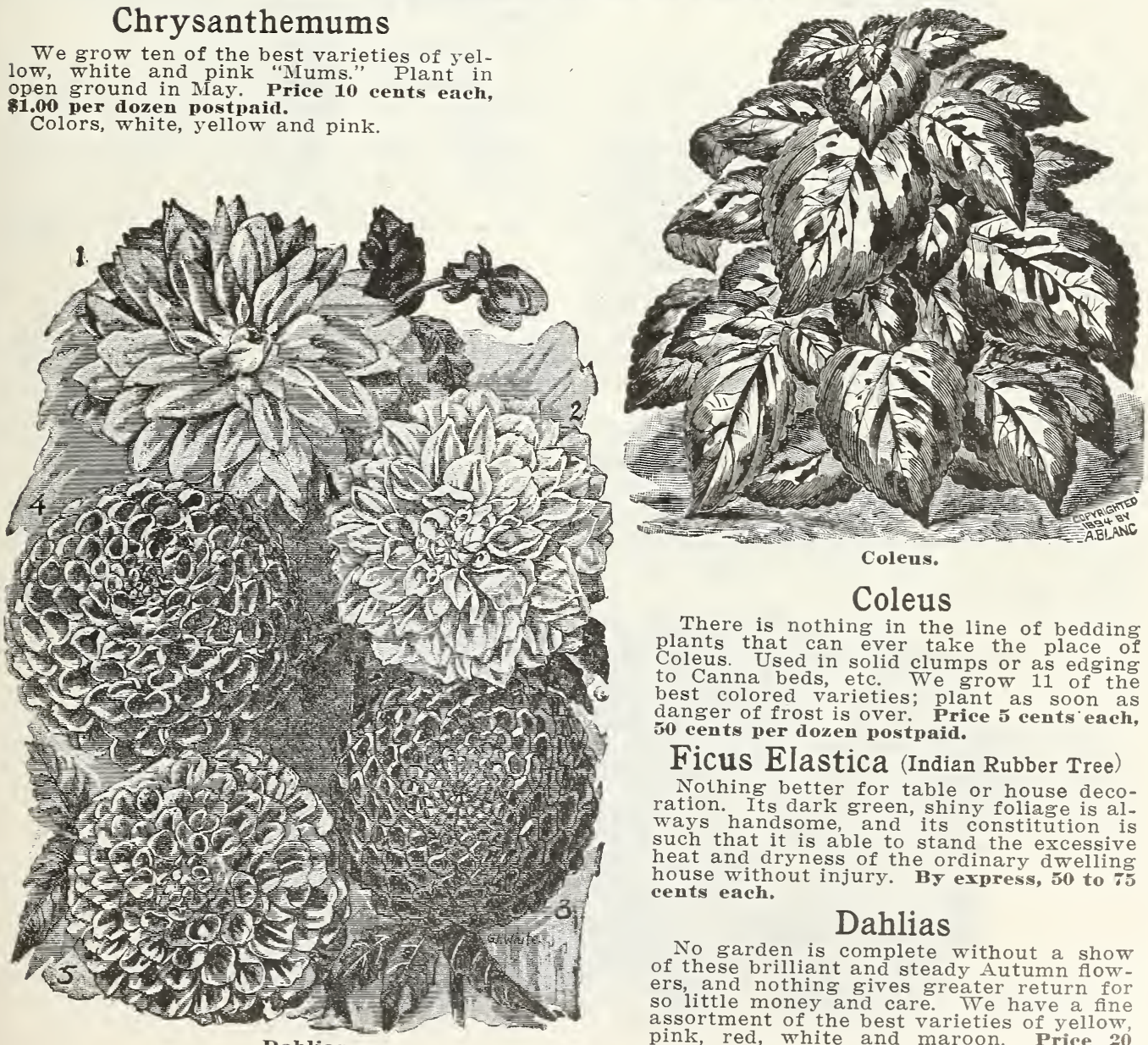

Coleus.

Coleus

There is nothing in the line of bedding plants that can ever take the place of Coleus. Used in solid clumps or as edging to Canna beds, etc. We grow 11 of the best colored varieties; plant as soon as danger of frost is over. Price $\mathbf{5}$ cents each, 50 cents per dozen postpaid.

Ficus Elastica (Indian Rubber Tree) Nothing better for table or house deco ration. Its dark green, shiny foliage is al ways handsome, and its constitution is such that it is able to stand the excessive heat and dryness of the ordinary dwelling house withou

\section{Dahlias}

No garden is complete without a show of these brilliant and steady Autumn flowers, and nothing gives greater return for so little money and care. We have a fine pink, red, white and maroon. Price 20 cents each, 6 for $\$ 1.00$ postpaid. 


\section{Fuchsias}

For window pot plants or for partially shady spots in the garden, these plants with their gracefully drooping flowers, are held in high favor. We grow 6 varieties. Price 15 cents each, 4 for 50 cents postpaid.

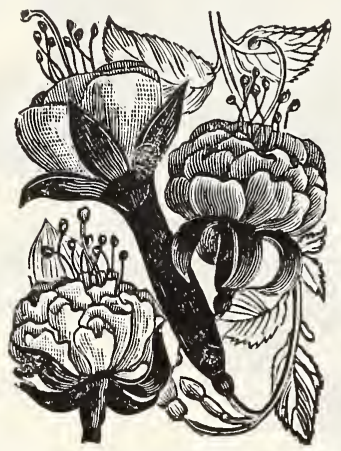

FUCHSIA.

\section{Ferns}

There are no more attractive plants, or plants that are more generally useful than Ferns. Their great beauty and diversity, together with their. adaptability in arrangement with all kind of flowering and ornamental plants make them an almost indispensable adjunct to the home and conservatory. Not requiring strong light they can be used to advantage in places the sun does not reach. Largely used also for cutting, as a few sprays serve to lighten and give an artistic finish to any bouquet or design. We list the most desirable varieties.

Whitman Fern. Similar to the Boston Fern only that the fronds are shorter and fringed. Prices same as Boston.

Boston. Sometimes called "Fountain Fern" on account of its gracefully drooping habit. Fully matured fronds often attain a length of four feet. Price 10 cents each.

\section{LARGE PLANTS BY EXPRESS.}

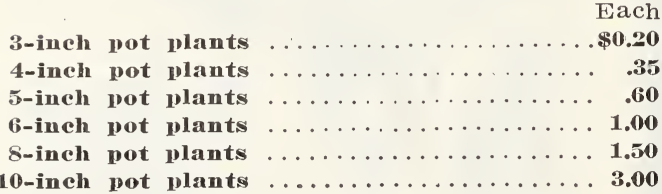

\section{Geraniums}

Throughout all the fluctuations of taste and requirements which popularize one class of plants and then another, Geraniums have held and still retain a foremost place in popular estimation, which seems impregnable. As pot plants, they are always serviceable and useful; while for summer bedding purposes they are almost indispensable.

\section{DOUBLE FLOWERING VARIETIES.}

Unless otherwise noted, price 10 cents each, \$1.00 per dozen postpaid. Geraniums in 4-inch pots for bedding out in May and June per dozen $\$ 1.75$, per $100 \$ 12.00$ by express at customer's expense.

Beauty Poitevine. One of the semi-doubles and has no equal in its color; trusses immense and of a fine shape; color beautiful rosy salmon, nicely shaded and tinted. Foliage thick, leathery; strong habit of growth.

Jean Viaud. A wonderful fine Geranium for winter or summer blooming. Flowers semidouble, of largest size, borne on immense stalks. Color fresh bright rose pink, the upper petals marked with white blotches, adding greatly to freshness of coloring; grand everbloomer, fine form.

La Favorite. Trusses very large; purest snow white, even when grown in the open ground.

Mrs. E. G. Hill. Large, single flowers; bright salmon, with a light shading at center.

S. A. Nutt. Rich crimson. The old standby.

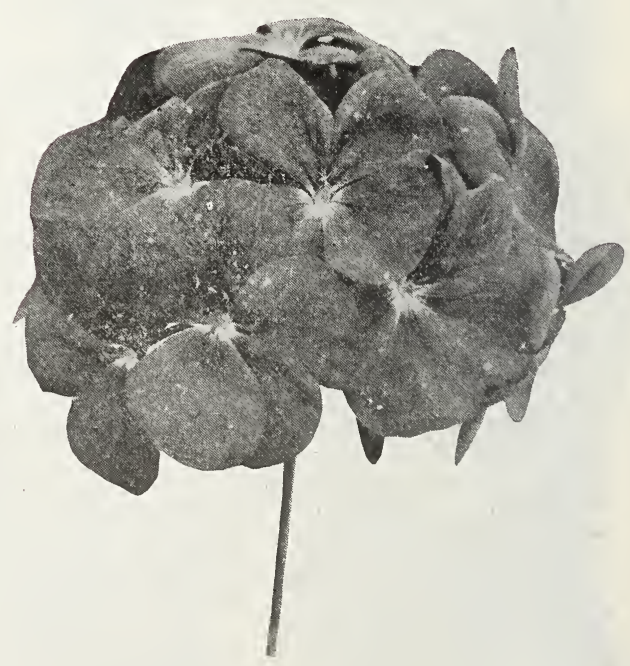

Geranium. 


\section{Heliotropes}

Heliotropes are great favorites, principally on account of their delicious fragrance; they grow freely under glass, and may be planted in the open border during the summer. Price 10 cents each, 6 for 50 cents postpaid.

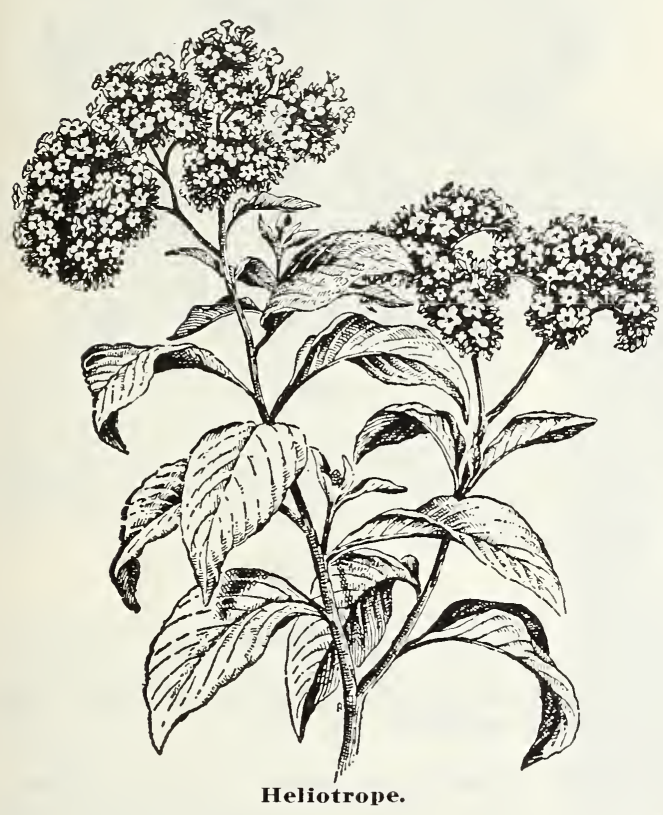

\section{Oleanders}

An old favorite, largely used for house, porch or lawn decorations Easily wintered in a cellar where it does not freeze. Pink and white. Double flowered. Price 20 cents each postpaid.

\section{Lantanas}

Lantanas. The Lantanas make fine bedding and basket plants and are increasing in favor They bloom continuously from spring until cut down by frost.

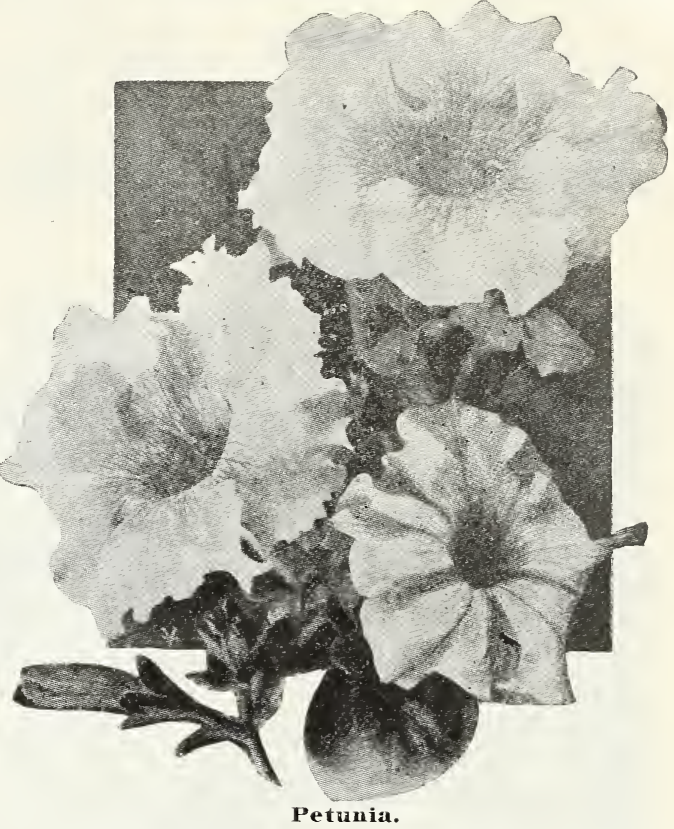

Weeping Lantanas. A most excellent plant for eeping Lantanas. A most excellent plant count of its bright colored bloom; flowers delicate rosy lilac, borne freely all over the.plant. Price 10 cents each.

Aurora. Pink and yellow center. Price 10 cents each.

Emily Bayard. Deep orange crimson, with yellow center. Price 10 cents each.

Favori. Light buff, changing to white. Price 10 cents each.

Harkett's Perfection. Golden variegated foliage; flowers, yellow and pink. Price 10 cents each, dozen $\$ 1.00$ postpaid.

\section{Petunias}

Very easily grown and truly satisfactory wherever placed.

Purity. A remarkable fine, double flower. Plant is strong and stock; flowers are very large and very double, also finely fringed. Color, pure white.

Double Pink. Double Crimson. Price 10 cents each, $S$ for 50 cents postpaici.

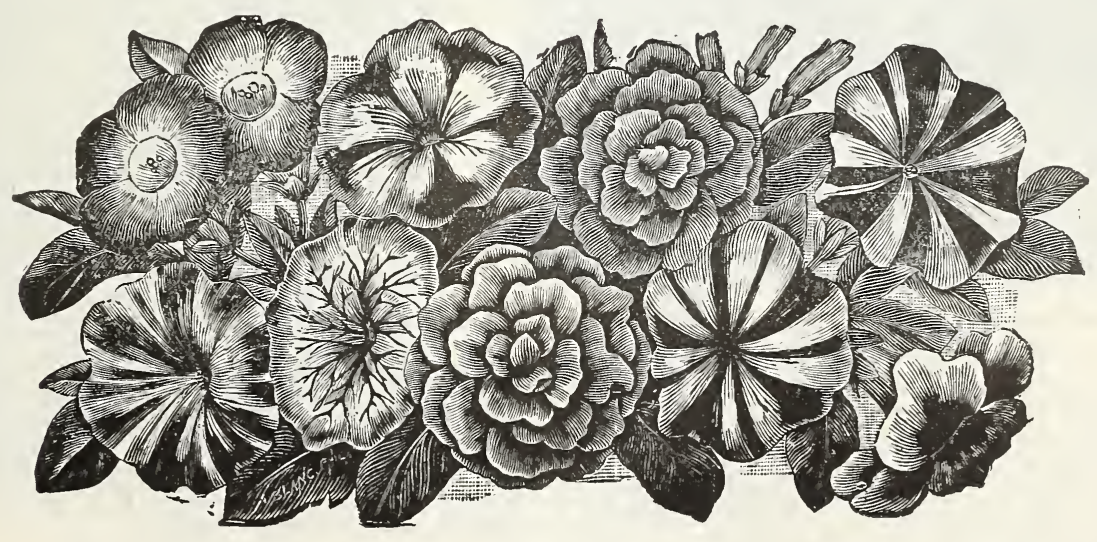




\section{Salvia}

Splendens. A remarkable fine bedding plant. The latter part of summer and early fall it is covered with great masses of dazzing scarlet flowers, which remain in bloom until cut down by frost. 10 cents each; 3 for 25 cents postpaid.

\section{Smilax}

Smilax. A very graceful climber, possessing the rare qualities of delicate and dense foliage and vining habit, admirably adapting it to climbing or drooping. It is fine as a parlor or window plant. 10 cents each postpaid.

\section{Moon Vine}

Moon Vine. One of the most rapid growing vines, often 40 feet in a single season, fine for trellises or screens, large white bloom. 10 cents each postpaid.

\section{Vinca Major Variegata}

Vinca Major Variegata. More of this used for baskets and vases than there is of any other two basket plants. Beautifully variegated green and white foliage, and strong trailing habit of growth. 15 cents each; 10 for $\$ 1.00$ postpaid.

\section{Tuberoses}

Excelsior Pearl. Double white, dwarf, seldom over 18 inches high. 5 cents each; 6 for 25 cents postpaid.

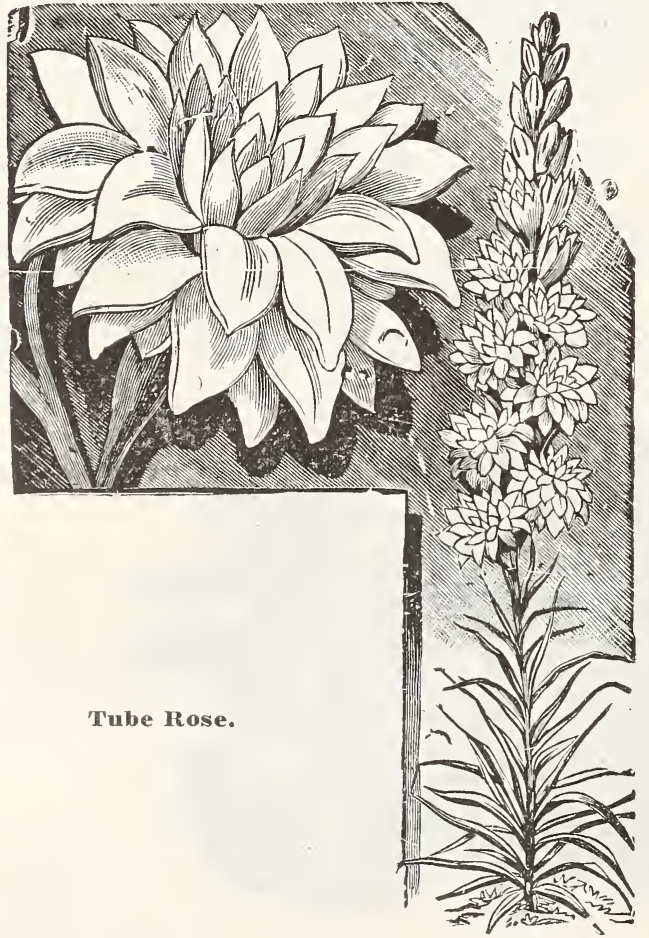

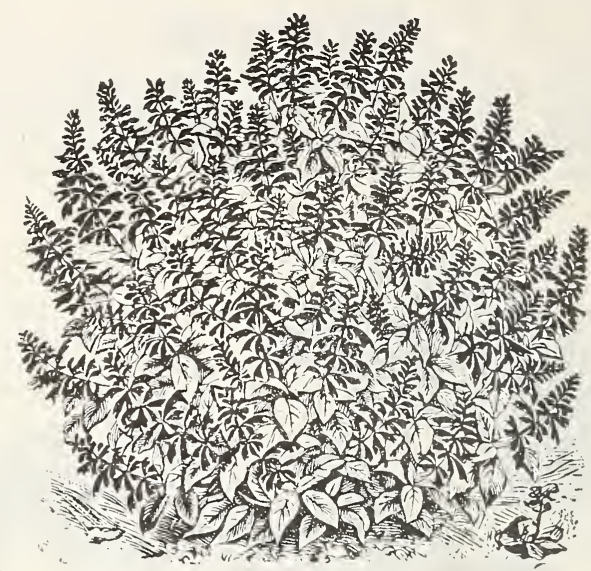

Salvia.

Mexican Tube Rose. Single white flower, very fragrant; blooms in July; will bloom anywhere in the United States. Each plant will send up two or more flower spikes. 5 cents each; 6 for 25 cents postpaid.

\section{Violets}

Violets, 10 cents each; 3 for 25 cents; $\$ 1.00$ per dozen postpaid.

Of all delightful perfumes, that of the Sweet Violet is the most delicate and pleasing. If grown in the house for winter flowers, they should be kept at a low temperature; they will not bloom freely where it is too warm. If left in the open ground during the winter, protect with a covering of leaves.

California. The plant is a robust grower and with dense, heavy foliage, entirely free from the disease that is so destructive to other sorts. Flowers single, intensely fragrant. Color, a clear, violet purple that does not fade. The flowers are very large and borne on stems ten to twelve inches long, giving them unusual value for cut flowers.

Princess of Wales. Broad Pansy-like flowers of a beautiful violet purple shade, with lighter center. A vigorous growing plant with clean, healthy foliage and stiff, long stems. One of the most beautiful and free flowering Violets.

\section{Hoyia}

Or Wax Plant. A fine climber, will grow best without sunlight; thick, shiny leaves and large, sweet scented waxy flowers. 25 cents each postpaid.

\section{Sultana}

Sultana, Charming plants for the decoration of the greenhouse or dinner table, producing bright, waxy-looking flowers profusely and al most continuously. The young seedlings should be carefully handled, as they are excedeingly brittle at the outset. Pink and white, 10 cents each; 5 for 50 cents postpaid. 


\section{Peonies}

That Herbaceous Peonies are as fine and effective in their way as Rhododendrons or Roses is now being generally recognized. They are hardier and more easily cultivated than either of their rivals andare being used in the same very lasting; some of them are finely finished and exquisitely colored. Plant in deep, wellprepared soil, covering the buds but an inch or two. Do not expect too much of them the first year. They are a little slow in establishing themselves.

Peonies are too large to be sent by mail. We can furnish red, white and pink, strong plants, 20 cents each; 6 for $\$ 1.00$.

\section{Delicatissima}

Delicatissima. This beautiful flower should be in every garden. Very large; delicate, clear pink, lighter in the center; very fragrant; free bloomer; exceptionally pretty in the bud; a quality flower in every sense. It is unexcelled as a cut flower. 35 cents each; $\$ 3.50$ per dozen.

\section{Festiva Maxima}

Festiva Maxima. About the largest and undoubtedly the most popular Peony of them all. High-built flowers borne on long, stiff stems; the purest white inner petals slightly tipped carmine. Early. 35 cents each; \$3.50 per dozen.

Edulis Superba. (Lemon.) Very large, bright rose flower; a beautiful early variety. 30 cents each.

Pottsii. Dark crimson; yellow stamens showing through the flower, early. 30 cents each.

Nigra. (Terry.) Full double flower; the darkest crimson of any; long, willowy stems; blooms late. 30 cents each.

Modest Guerin. Brilliant carmine-rose, with a high and stiff center full of rosy-pink petals 35 cents each; $\$ 3.50$ per dozen.

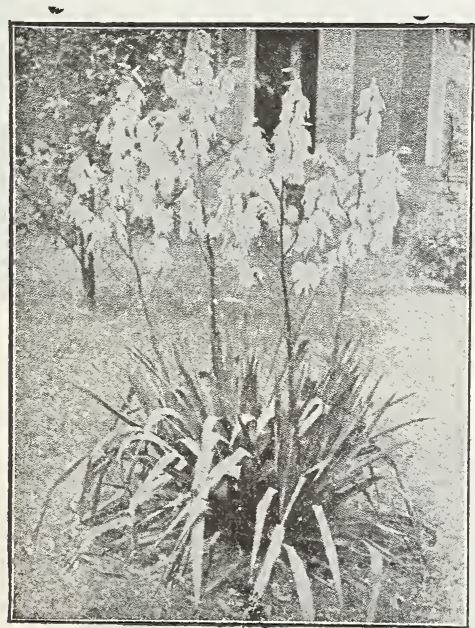

Yucea Filamentosa
Queen Victoria. The broad guard petals are a pretty bluish white; center slightly edged pink. Large. 30 cents.

\section{Feverfew}

Feverfew. A fine house plant with bright foliage and double pure white flowers. 10 cents each; 3 for 25 cents postpaid.

\section{Golden Glow}

Rudbeckia "Golden Glow." The most prolific and satisfactory hardy perennial of all yellow flowering sorts. Grows 5 to 7 feet and blooms



Festiva Maxima

from early summer until frost. Flowers are produced on long stems in enormous quantities and resemble golden-yellow Cactus Dahlias. 10 cents each: 75 cents per dozen postpaid.

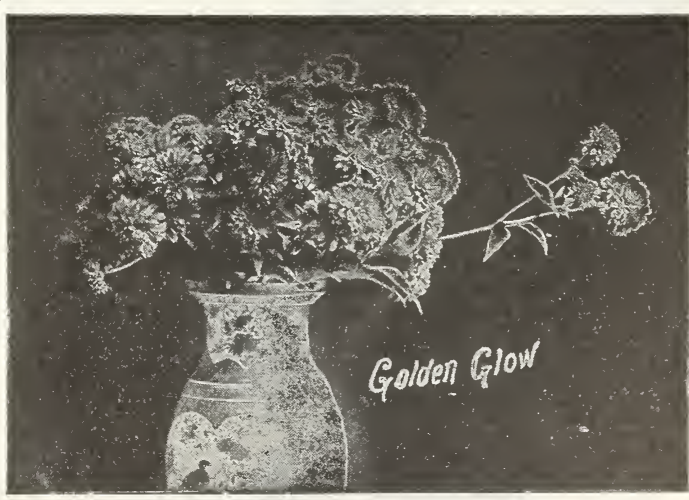

\section{Yucca Filamentosa}

Yucea Filamentosa (Adams' Neddle or Spanish Bayonet). A stately foliage and flowering plant equally imposing in solitary or group plantings, always conspicuous. The broad, sword-like foliage is evergreen; while midsummer shows great, erect branching stems bearing a showy display of pendant creamy-white bells, strong. 3 -year by express, 25 cents each; $\$ 2.50$ per dozen. 


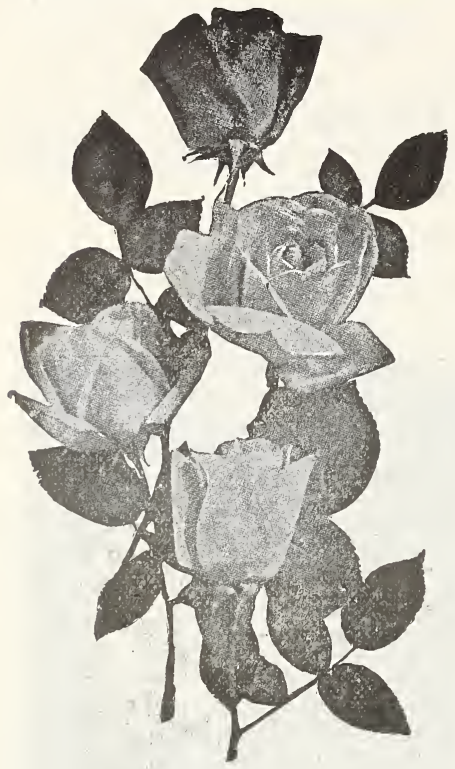

Killarney

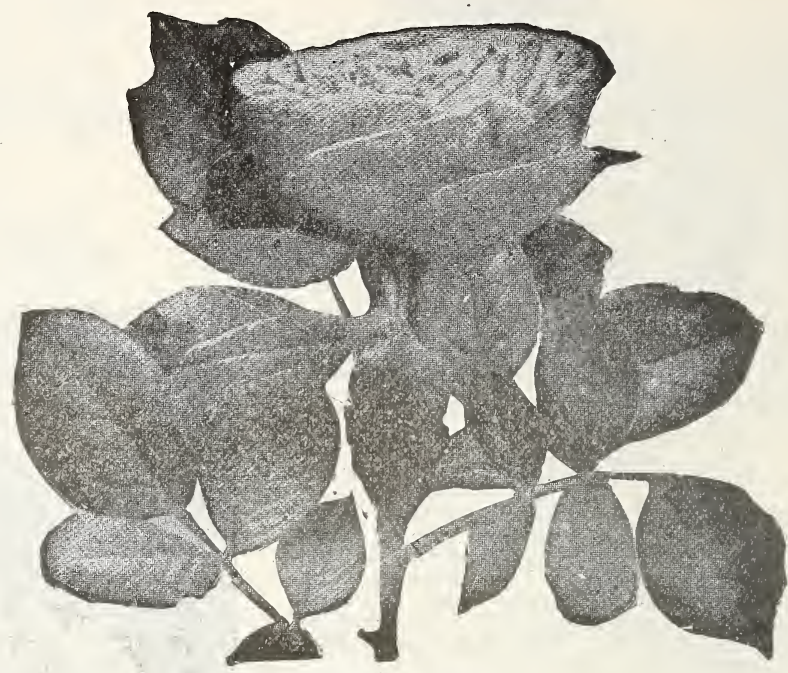

American Beauty

\section{Roses}

Roses thrive best in a good, well-drained clay soil where they can have plenty of sunlight Make the ground rich with well-rotted manure, and in the spring severely prune all varieties except climbers and Persian Yellow. Cover in the fall with some coarse, dry material. 15 cents each; 8 for \$1.00. These prices are for small plants, from $21 / 2$-inch pots. Postpaid.

American Beauty. Large, globular, deep pink, shaded with carmine; delicious fragrance; a most desirable variety of forcing.

Perle des Jardins. Beautiful clear yellow, flower large and fine form.

Killarney. Bright pink with lemon at base of petals. Large, long, pointed buds of great beauty and sweetly fragrant. A charming variety.

Richmond Beauty. Fine shape and brightly colored in pure dark scarlet crimson.

White Killarney. A pure white sport of the popular Killarney Rose, identical in every way with its parent, excepting in color, which is a pure white.

Kaiserin Augusta Victoria. The finest white everblooming hardy garden rose. Soft, pearly white, lightly tinted with lemon in the center, just enough to relieve the white. Remarkably fragrant buds and open flowers of elegant form. The plant is a strong grower, blooms freely, and the flowers are carried on long, stiff stems.

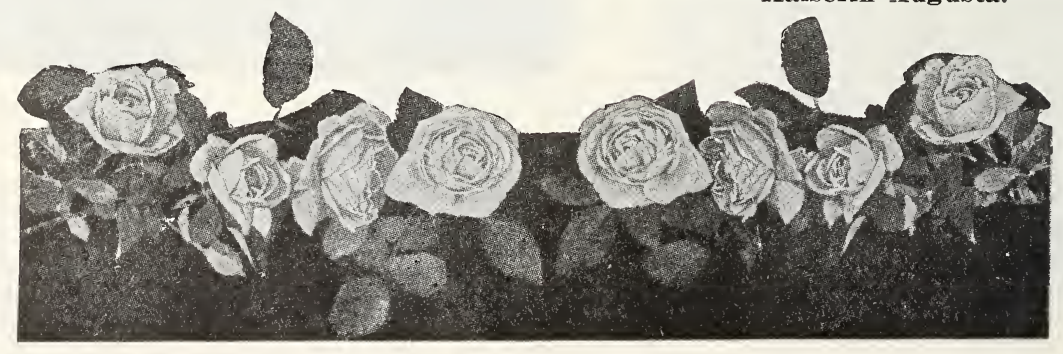

Kaiserin Augusta.

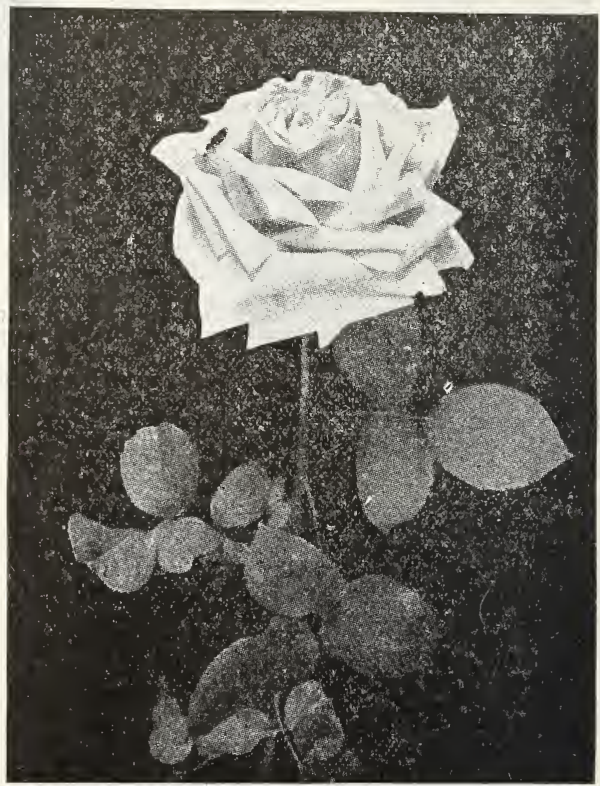




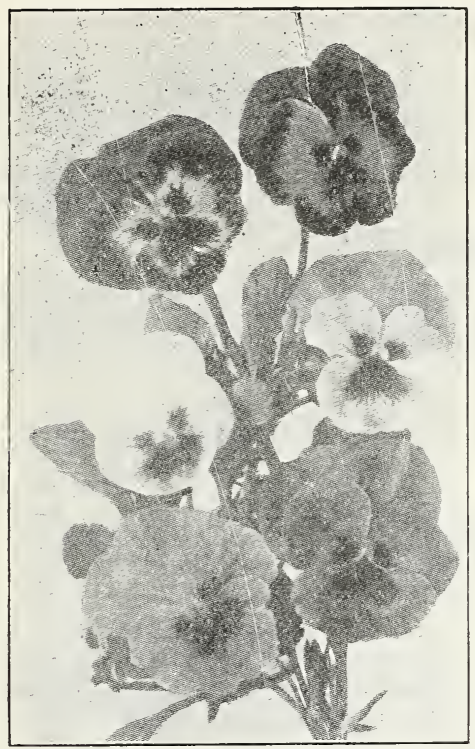

Pansy

\section{Umbrella Plant}

Umbrella Plant. An excellent plant for the house. Will thrive in any good soil and always presents a green and attractive appearance. It may be grown as a sub-aquatic, and in any case should never lack a liberal supply of water. 10 cents each; 6 for 50 cents postpaid.

\section{Phlox}

No class of hardy plants is more desirable than the Perennial Phloxes. They will thrive in any position and can be used to advantage in the hardy border, in large groups on the lawn. By judicious pinching back and removing faded flowers, a constant succession of bloom may be had until frost. Mixed colors: Red. white, pink and lavender. 15 cents each; $S$ for $\$ 1.00$.

\section{California Moss Pink}

A plant not well known, but we consider it among the very best for hanging baskets or planted in open ground. Postpaid, 10 cents each. $\$ 1.00$ per dozen.

\section{Assorted Plants}

We can furnish the following small plants postpaid at prices named below.

Snapdragon. Red, white and pink. 10 cents each; $\$ 1.00$ per dozen.

Asters. Assorted colors. 5 cents each; 40 cents per dozen.

Sweet Alyssum. 5 cents each; 40 cents per dozen.

Cosmos. Assorted colors. 5 cents each; 40 cents per dozen.

Marguerite Dais:. 10 cents each; $\$ 1.00$ per dozen.
German Ivy, 10 cents each; $\$ 1.00$ per dozen. Pansies. Assorted colors. 5 cents each; 50 cents per dozen.

Verbenas. White, red, pink and blue. 5 cents each; 50 cents per dozen.

Wandering Jew. Red and green. 5 cents each; 40 cents per dozen.

\section{Dicentra (Bleeding Heart)}

D. Spectabilis. A hardy perennial with heartshaped rose-colored flowers in drooping spikes. One of the best border plants. Perfectly hardy and easily cultivated; 2 feet high. Flowers in April or May. 25 cents each.

\section{Bulbs for Fall}

Hyacinths. Red, white and blue. 10 cents each; 3 for 25 cents.

Crocuses. Assorted colors. 5 cents each; 6 for 25 cents.

Narcissus. Pure white. 5 cents each; 6 for 25, cents.

Tulips. Assorted colors, single and double. 5 cents each; 50 cents per dozen.

\section{Bulbs for Spring}

L. Auratum. Gold-Banded Lily of Japan. Flowers very large, delicate ivory white, thickly dotted with rich chocolate spots. A bright, golden band runs through the center of each petal. The finest of all Lilies. 20 cents each; 3 for 50 cents.

L. Harrisii (Bermuda Easter Lily). Flowers large, trumpet-shaped, pure waxen white, gracefully formed and delightfully fragrant. The ease with which it can be forced into flower in winter has made it wonderfully popular for church decoration at Easter. 20 cents each; 3 for 50 cents.

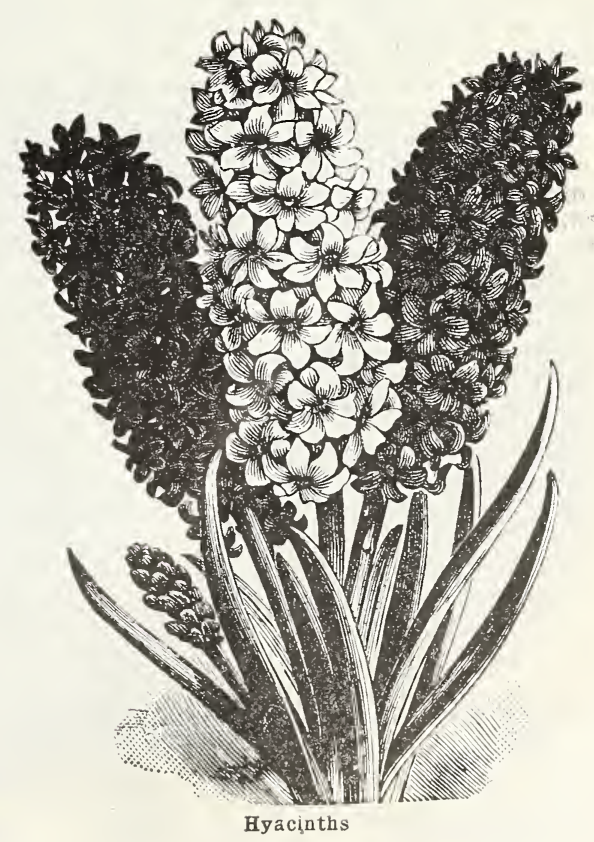




\section{Notice}

On the 1st day of September, 1914, we purchased the nursery business and good will of the Galbraith Nurseries, and of D. Hansen, the Nurseryman, and from then on the three nurseries will be run under the name of Fairbury Nurseries. Any orders received from their former patrons will be appreciated and shall receive our best attention in filling and shipping the same.

\section{Special Advertised Offers}

25 Grafted Apple Trees, $\$ 1.00$. These are trees 2 to 3 feet in height, well rooted and healthy.

25 Budded Peach Trees for $\$ 1.00$. These are 18 to 24 inches in height, well rooted and fine for transplanting. 50 Concorn Grape Vines for $\$ 1.00$. These vines are one year old with good root growth.

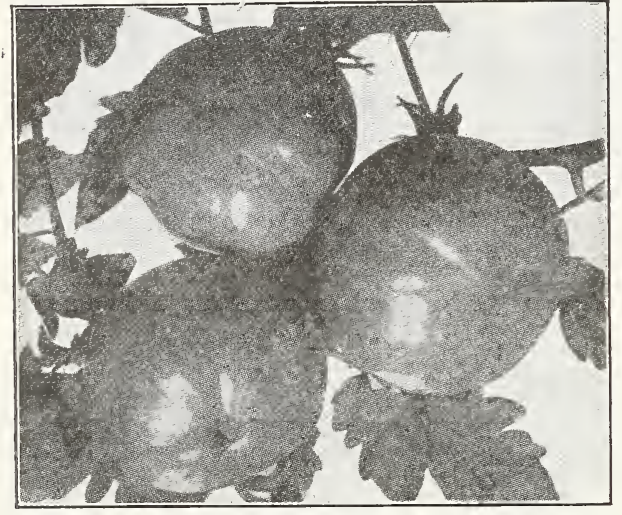

Earliana.

\section{Tree Protectors}

Price-2 Cents Each; $\$ 1.50$ per 100

Same are made of veneer and are the best and easiest applied of anything ever used. Two men can wrap 1,000 trees a day. They are 18 to 24 inches long, 9 to 12 inches width and one-twelfth inch thick, and are fastened with small wire around the center, and will last from three to five years.

Will protect your trees from rabbits, mice and borers; will also protect the stems from sunscald, and can be left on during the summer and will not injure the tree. They are furnished green, tied in bundles of 100 each, and are ready for use. Soak in water before applying.

\section{Plants}

In the spring of each year we grow large quantities of such plants as Sweet Potatoes, Tomatoes, Cabbage, Peppers and Celery. We ship by prepaid postage, or where sent by express the customer pays the expressage.

\section{Egg Plant}

20 cents per dozen Postpaid.

\section{Sweet Potatoes}

Yellow Nansemon and Yellow Jersey

Plants are usually ready for shipment May 10.

Per Per

By Mail, prepaid .....\$ \$0.50

$100 \quad 1,000$

By Express ............... .25

$\$ 2.00$

\section{Tomatoes}

Per 100 Per 1,000

Earlianna, Champion and Stone

By Mail ...............\$0.75

By Express ............. .50

$\$ 4.50$

\section{Cabbage}

Early Wakefield, Surehead and Holland Seed

By Mail ..............\$0.50

By Express .............. .30

By Express, Surehead after

June $1 \ldots \ldots \ldots \ldots \ldots \ldots .25$

$\$ 2.50$

\section{Celery}

Golden Self Blanching and Silver Plume

Celery grows very slowly when small and we cannot ship until June 1 .

By Mail ..............\$0.50

By Express ............... $35 \quad \$ 3.00$

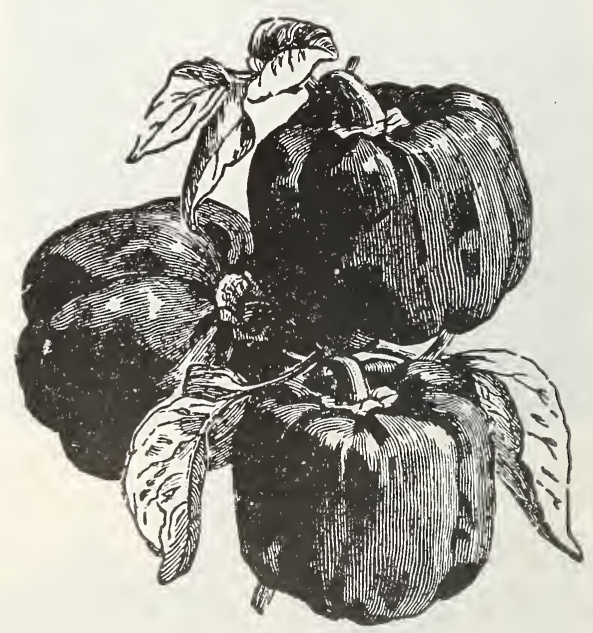

Giant Sweet.

\section{Pepper}

Giant Sweet, Mango and Cayenne

By Mail .................\$1.00

By Express ................. . . . 


\section{Seed Potatoes}

We are now prepared to furnish our customers with first-class seed potatoes and would be pleased to receive a trial order from you.

Extra Early Ohio-(Red River Grown)-This is without doubt the most popular early potato in the country. We have more calls for it than any other early. Everyone knows what it is and that it can be relied upon for an early market variety in almost every locality. They are smooth, clean and free from prongs and scab. They grow stronger and more vigorous, maturing the crop in shorter time and yielding much more than home-grown seed, so that there is the utmost satisfaction in planting them. Potato growers in the South will have their crop ready for the market from ten days to two weeks earlier if our Red River Valley Ohios are planted. This variety is sometimes sold under the name of Early Six Weeks Potato. It will pay to change your seed this year and plant a few acres of our selected stock of Ohios. Price, peck, 40 cents; bushel, $\$ 1.50$; three bushels, $\$ 4.00$.

Rural New Yorker-Is a large, white-skinned variety, oval in form, and rather flattish; flesh is white and close-grained, solid and of the very best quality; it cooks dry and floury; eyes are few and shallow. The tubers are large and the smoothest and cleanest of all potatoes grown. Although it is a large yielder, it grows but few and small vines. It is very hardy and will stand the heaviest manuring without getting rough or scabby. Price, peck, 30 cents; bushel, $\$ 1.00$; three bushels, $\$ 2.75$.

Early Irish Cobbler-In shape the Cobbler is round, with oval cross-section. Skin white, well netted. Flesh pure, pearly white. Eyes are very few and shallow. Its cooking qualities and flavor are first class. Tubers are of good size, no small ones, and very smooth and free from scab. It is one of the most reliable of the first early sorts. It ripens very evenly, every hill seeming to ripen at one time. Its strong growth, earliness, productiveness, fine eating quality and handsome appearance will always cause a good demand for the Early Irish Cobbler. Price, peck, 40 cents; bushel, $\$ 1.50$; three bushels, $\$ 4.00$.

\section{Seed Sweet Potatoes}

Yellow Jersey, 5 cents per pound by express. Do not order them shipped until you are ready to plant them. 12 cents per pound by mail postpaid.

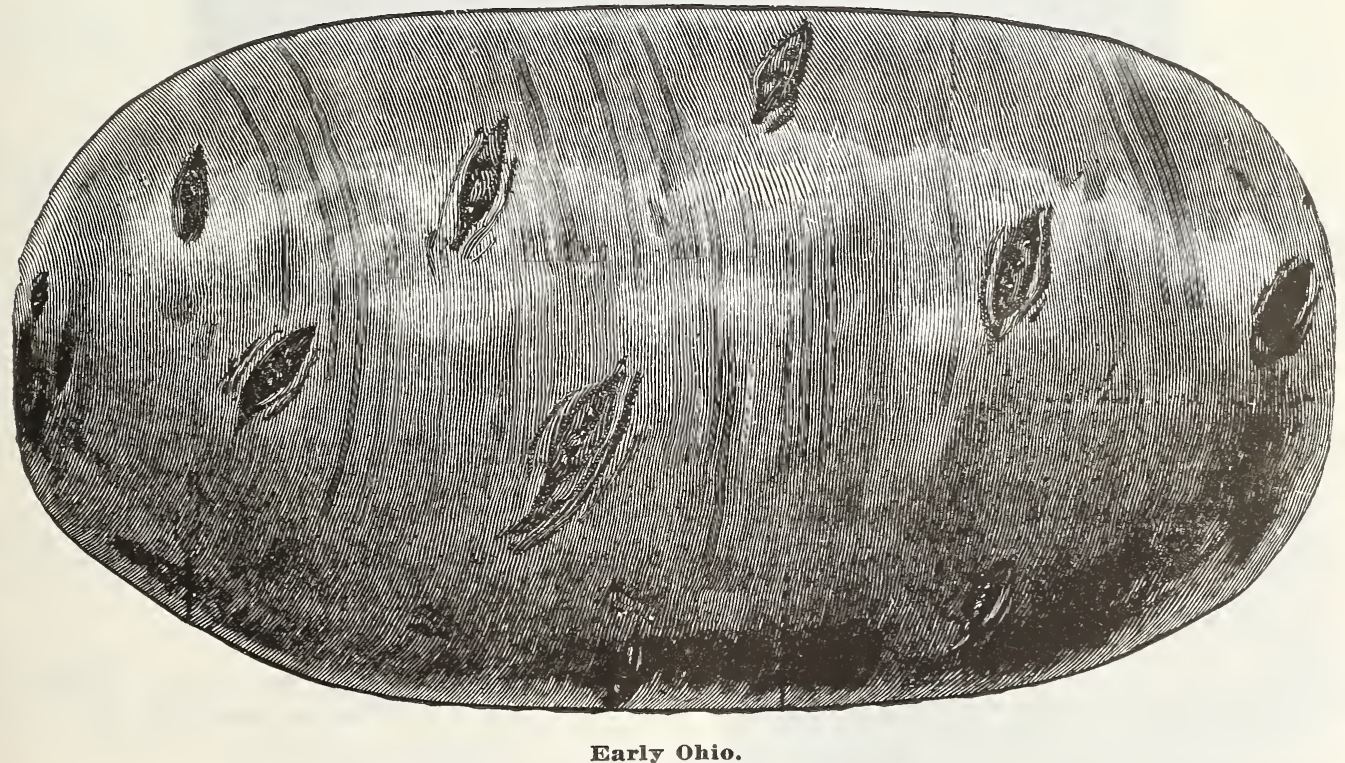

Customers pay the freight or express on potatoes. 


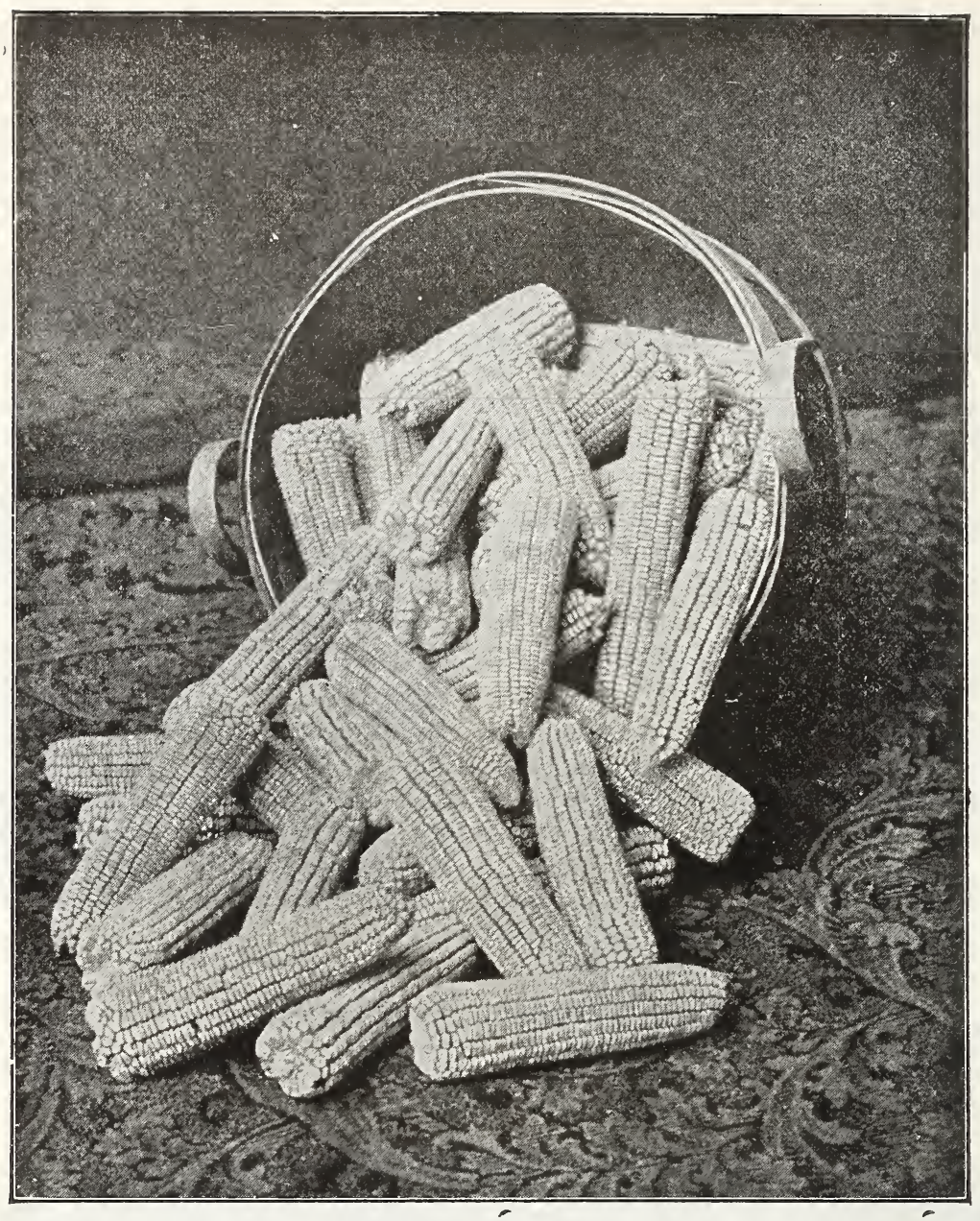

Johnson County White.

\section{Seed Corn}

Johnson's County White-A variety of large white corn wisich wins over all other varieties at state and national corn shows. We secured seed of this valuable variety from a man in Ohio who grows the pure Clore strain, and who purchased for $\$ 350$ the Grand Sweepstakes Prize ten ears of this variety at the National Corn Show, Columbus, Ohio. We recommend this variety to our customers. Price, for selected seed, peck, 40 cents; bushel, $\$ 1.50$; five bushels, $\$ 7.00$.

\section{Sweet Corn}

Stowell's Evergreen. The standard variety. Very productive; ears large; grain deep, exceptionally tender and sugary, and remains long in edible condiion. Thirty cents per quart,

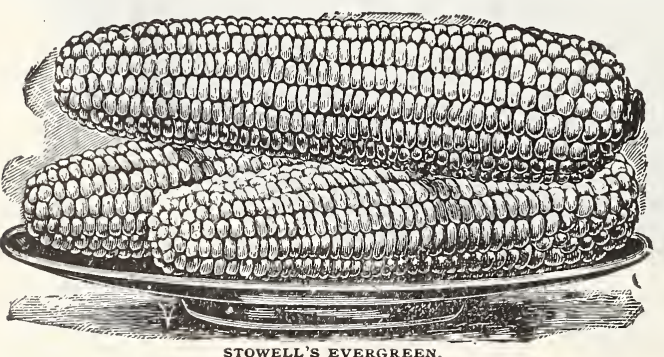
postpaid; peck, 80 cents; $1 / 2$ bushel, $\$ 1.50$; bushel, $\$ 2.75$. 


\section{Parcel Post-Trees and Plants by Mail-Parcel Post}

\section{ITEES OF SIZES LARGER THAN QUOTED BELOW CANNOT BE SENT BY MAIL.}

I can now send trees and plants of suitable sizes by Parcel Post, and they will be delivered right at your door. No need of going to town after them, and I know they will not cost you more than half as much as if you buy of an agent. I pay postage on all mail packages. The prices here below are for goods delivered at your door. Trees will be well rooted, sound and packed to reach destination in good condition. Two to three feet, three to four feet and four to five feet. Larger trees cannot go by parcel post, as the circumference and length of a package cannot exceed eighty-four inches. Always use prices given below if you wish trees by parcel post.

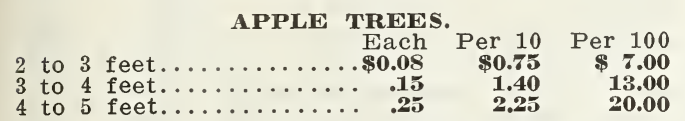

4 to 5 feet...................

SEEDLESS APPLE.

Each Per 10

to 3 feet....................

3 to 4 feet.................45 $\mathbf{4 . 0 0}$

4 to 5 feet.............. .50 $\mathbf{5 . 0 0}$

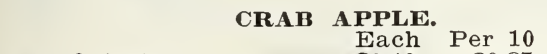

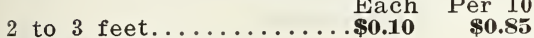

3 to 4 feet...............16

4 to 5 feet..................

PEAR STANDARD.

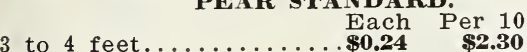

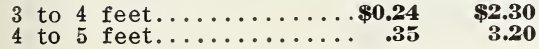

PEAR DWARF.

Each Per 10

2 to 3 feet..........\$0.20 P $\$$ \$1.75

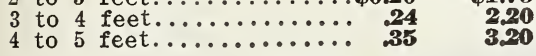

NECTARINE.

3 to 4 feet........... $\underset{\$ \$ 0.35}{\text { Each }} \underset{\$ \$ 2.25}{\operatorname{Per} 10}$

BUDDED PEACH.

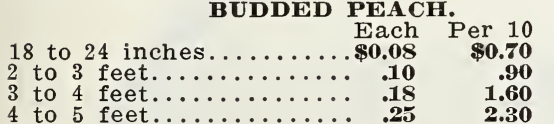

MAYFLOWER PEACH.

Each Per 10

2 to 3 feet........... $\$$ E0.16

er 10

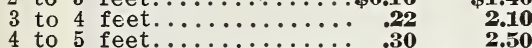

2.50

SEEDLING PEACH.

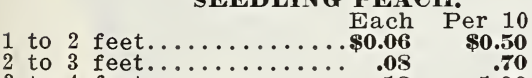

2 to 3 feet.............08

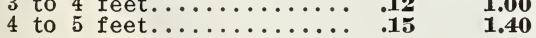

PLUM.

2 to 3 feet............ Each Per 10

3 to 4 feet .......................

4 to 5 feet................4

OPATA, SAPA AND HANSKA PLUM.

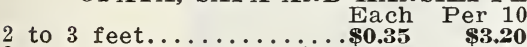

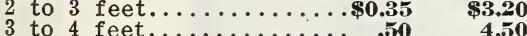

CHERRIES.

Each Per 10 Per 100

1 to 2 feet.........\$0.15 $\underset{\$ 1.30}{\$ 1.30}$

2 to 3 feet. $\ldots \ldots \ldots \ldots \ldots \ldots \ldots r . \mathbf{2 0} \quad \mathbf{1 . 8 0}$

4 to 5 feet.............

COMPASS CHERRY.

Each Per 10 Per 100

2 to 3 feet........... $\underset{\$ 0.22}{\text { Each }} \underset{\$ 2.00}{\text { Per } 10}$

3 to 4 feet................30

4 to 5 feet...........................

ROCKY MOUNTAIN CHERRY.

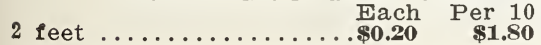

Per 100 $\mathbf{1 4 . 0 0}$
$\mathbf{8}$ $\mathbf{2 0 . 0 0}$

Per 100

Per 100

Per 100

Per 100
$\$ \mathbf{5 . 0 0}$
$\mathbf{8 . 5 0}$
$\mathbf{1 5 . 0 0}$

Per 100

$\$ 12.00$

18.00

Per 100

$\$ 4.00$

9.00

12.00

Per 100

Per 100

Per 100

100

Per 100

QUINCE.

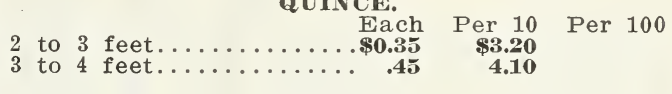

APRICO'T.

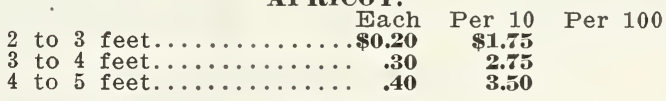

GRAPES.

Add 2 cents to catalog price for each vine

GOOSEBERRY.

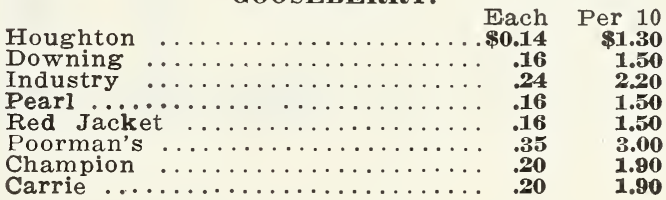

CURRANTS

Add 4 cents to catalog price for each one ordered.

RASPBERRIES.

Add 2 cents to catalog price on each plant ordered.

BLA CKBERRIES.

\begin{tabular}{|c|c|c|c|c|}
\hline \multicolumn{5}{|c|}{ 的 } \\
\hline & & Each & Per 10 & Per 100 \\
\hline ri & & $\$ 0.06$ & $\$ 0.50$ & $\$ 3.50$ \\
\hline $1 \mathrm{y} \mathrm{H}$ & Harves & .06 & .50 & $\mathbf{3 . 5 0}$ \\
\hline ler & $\cdots \cdots \cdots$ & .06 & .50 & \\
\hline e's & Hardy & .06 & .50 & 3.2 \\
\hline egon & $\ldots \ldots$ & $\ldots \ldots \ldots$ & 1.00 & 9.00 \\
\hline
\end{tabular}

Oregon .................... $\mathbf{. 1 5} \quad \mathbf{1 . 0 0} \quad \mathbf{9 . 0 0}$

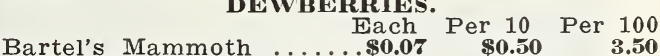

$\begin{array}{lcccc}\text { Bartel's Mammoth } \ldots \ldots \ldots . \$ 0.07 & \$ \mathbf{\$ 0 . 5 0} & \mathbf{3 . 5 0} \\ \text { Lucretia } & \ldots \ldots \ldots \ldots \ldots \ldots \ldots & \mathbf{. 0 7} & \mathbf{. 5 0} & \mathbf{3 . 5 0}\end{array}$

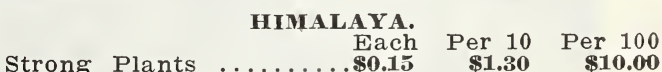

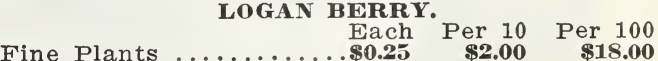

BUFFALO BERRY.

Each Per 10 Per 100

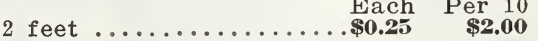

WINE BERRY

Fine Plants .........\$\$\$.20 $\underset{\$ \mathbf{\$ 1 . 7 5}}{\text { Each }}$ Per 10 Per 100

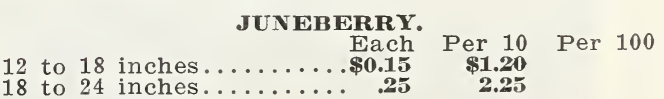

STRAWBERRIES.

All Varieties Except Progressive and Superb

25 plants ................... \$0.25

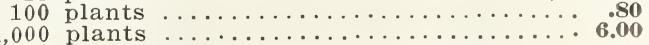

\section{PROGRESSIVE AND SUPERB.}

25 plants

$\$ 0.75$

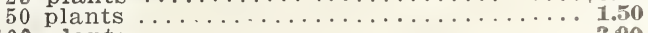

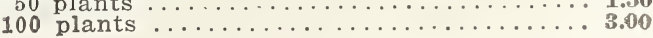




\section{TREES AND PLANTS BY MAIL-Continued}

MULBERRY.

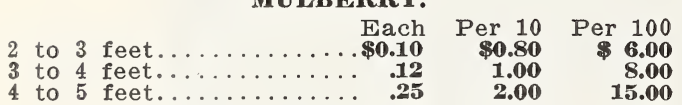

\section{EVERGREEN SEEDLINGS.}

\begin{tabular}{|c|c|c|c|}
\hline & & Per & Per \\
\hline Arbor Vita, 4 & $\begin{array}{l}\text { Each } \\
\text { So.07 }\end{array}$ & $\begin{array}{c}10 \\
80.50\end{array}$ & $\begin{array}{r}100 \\
\$ 130\end{array}$ \\
\hline Blue Spruce, 4 to 6 inches. & .07 & 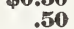 & $\$ 2.00$ \\
\hline Norway Spruce, 8 to 10 inche & .06 & .50 & $\mathbf{3 . 0 0}$ \\
\hline Aus. Pine, 6 to 10 inches.... & .06 & .50 & $\mathbf{3 . 0 0}$ \\
\hline Scotch Pine, 6 to 12 inches. & .06 & .50 & 2.75 \\
\hline White Pine, 4 to 8 inches.. & .05 & .30 & 2.00 \\
\hline Jack Pine, 6 to 12 inches. & .0 & .50 & 3.00 \\
\hline ed Cedar, 6 to 8 inches. & .10 & .90 & 8.00 \\
\hline
\end{tabular}

\section{FOREST SEEDLINGS.}

Per 100 Per 1,000

Ash, 6 to 10 inches..........\$0.35 $\$$ \$3.20

Ash, 10 to 15 inches................

Box Elder, 6 to 10 inches........

Box Elder, 10 to 15 inches..........

Black Locust, 5 to 8 inches...... $\mathbf{. 2 0}$

Black Locust, 8 to 12 inches........

Black Locust, 12 to 18 inch............35

Honey Locust, 6 to 12 inches . . .

Honey Locust, 12 to 18 inches....60

Thornless Honey Locust, 6 to 12 in. $\quad .60$

Thornless Honey Locust, 12 to 18 in. $\mathbf{. 7 5}$

4.20

5.40

5.40

7.00
Soft Maple, 6 to 12 inches.........35

Soft Maple, 12 to 18 inches........

Sugar Maple, 12 to 18 inches.... .75

White Elm, 6 to 12 inches..............

White Elm, 12 to 18 inches........45

Catalpa, 6 to 12 inches.............30

Catalpa, 12 to 18 inches............40

Cottonwood, 10 to 15 inches....... $\mathbf{. 3 0}$

Linden, 12 to 18 inches.......

Sycamore, 12 to 18 inches........

Mulberry, 6 to 12 inches...................

Mulberry, 12 to 18 inches........

HEDGE PLANTS.

Amoor Privet, 6 to 12 inches..... $\mathbf{. 3 5}$

Hardy Privet, 6 to 12 inches......

Osage, 6 to 12 inches..............30

APPLE GRAFTS.

Piece Root ............... 1.20 $\mathbf{1 0 . 0 0}$

16.00

\section{NUT TREES.}

$\mathbf{3 . 2 0}$
$\mathbf{4 . 5 0}$
$\mathbf{7 . 0 0}$
$\mathbf{3 . 2 0}$
$\mathbf{4 . 0 0}$
$\mathbf{2 . 5 0}$
$\mathbf{3 . 5 0}$
$\mathbf{2 . 5 0}$

$\mathbf{3 . 2 0}$
$\mathbf{4 . 2 0}$

$\mathbf{3 . 0 0}$
$\mathbf{2 . 5 0}$
$\mathbf{2 . 5 0}$

$\mathbf{1 0 . 0 0}$
$\mathbf{1 6 . 0 0}$

Per
100
$\$ 3.75$
1.35
1.70

1.70

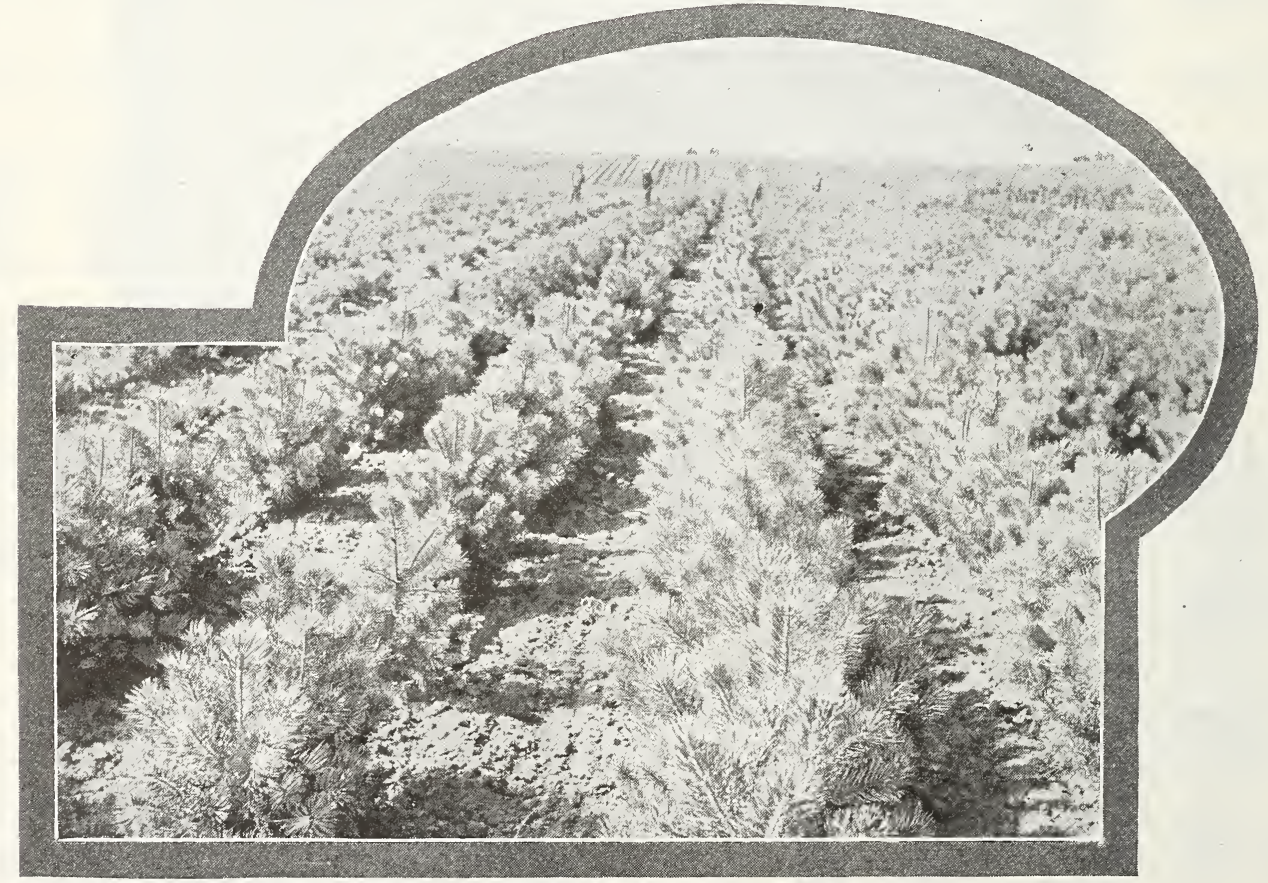

\section{Fairbury Nurseries \\ Fairbury, Nebraska}




\section{Barred Plymouth Rocks}

We have been breeding and showing Barred Plymouth Rocks for the past twelve years, not so much for the money there is in it for us (they are very profitable), but because they are a popular variety, hard to breed to the standard of perfection, and there is always such hot competition in this variety at our large shows that the breeder who can win a few first or second premiums has won something he may well be proud of.

Prices-Eggs from pens mated to produce exhibition cockerels and pullets, $\$ 2.50$ per 15 eggs; eggs from birds that have farm range, $\$ 1.00$ per 15 eggs; $\$ 3.00$ per 50 eggs.

Cockerels-At $\$ 2.00$ each. If you want show birds, write us for prices. ........

\section{Buff Cochin Bantams}

We also have a fine lot of Buff Cochin Bantams which are well-bred stock. They make fine pets and are good layers. No eggs for sale. We can furnish pairs for $\$ 2.00$, $\$ 3.00$ and $\$ 4.00$ per pair, according to their value as show birds.

\section{Angora Cats}

We are breeding long-haired Angora Cats. These make the finest of pets and are also good mousers. Colors are mostly white, some mixed with buff. Prices run from $\$ 5.00$ to $\$ 10.00$ each. If you are interested write us for prices on kittens we have on hand.

\section{State Entomologist's Certificate of Nursery Inspection}

THIS IS TO CERTIFY That on the 19th day of August, 1915, the growing stock and premises of the FAIRBURY NURSERIES, C. M. Hurlburt, Prop., of Fairbury, Neb., was inspected, and no San Jose scale was found nor any indication that it had ever been present in the nursery or its vicinity. The stock is apparently in a healthy condition and free from other dangerous insect pests and fungous diseases.

This certificate is good until July 1, 1916.

LAWRENCE BRUNER, State Entomologist.

By R. W. Dawson, Deputy. 


\section{Index}

Page

Page

Apple $\ldots \ldots \ldots \ldots \ldots \ldots \ldots \ldots \ldots \ldots$

June Berry ...................27

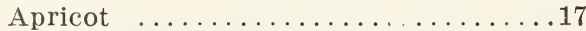

Japan Wineberry ................28

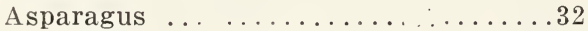

Blackberry ................26

Logan Berry ................27

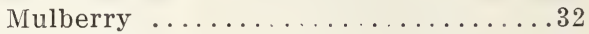

Buffalo Berry ...............28

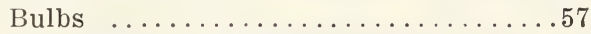

Nectarines ...................

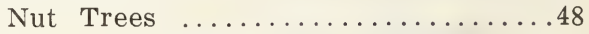

Crab Apple ............... 9

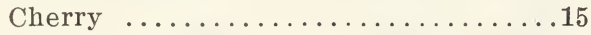

Compass Cherry ..............16

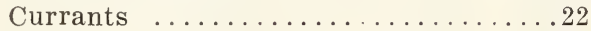

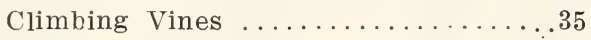

Cuttings $\ldots \ldots \ldots \ldots \ldots \ldots 4$

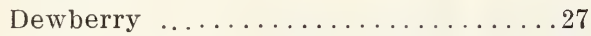

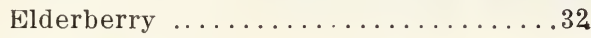

Evergreens .................44

Forest Tree Seedlings ............46

Grapes ....................18

Gooseberry ..................20

Grafts ................. 48

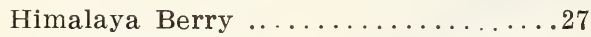

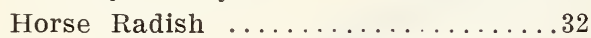

Hedge Plants ................47

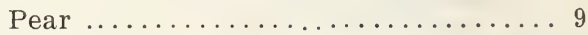

Peach ....................

Plum .....................

Plants ................... . . 49

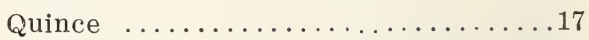

Rocky Mt. Cherry .............16

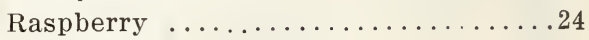

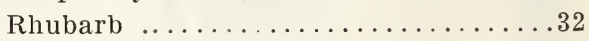

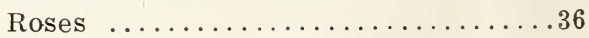

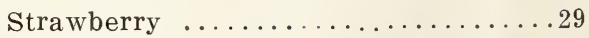

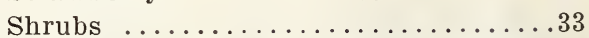

Shade Trees ................40

Seeds ...................448

Seed Potatoes .............660

Seed Corn .................60

Tree Protectors .............58

\section{FAIRBURY NURSERIES}

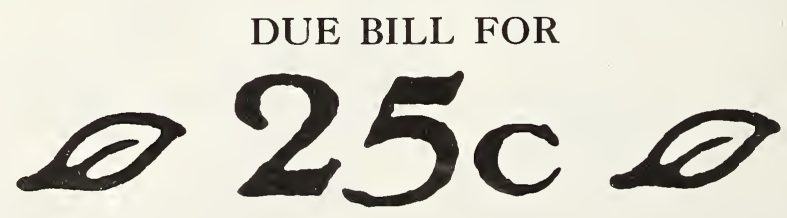

FAirbury, Neb. January 1, 1916.

This Due Bill will be accepted for Twenty-five Cents in Nursery Stock from any customer whose order amounts to One Dollar or more for Nursery Stock. $\quad$ C. M. Hurlburt.

\section{Not Good on Orders to be Sent by Mail One Only Good on Club Orders}

Address C. M. HURLBURT, Fairbury, Neb. 


\section{Ghoicest Gladiolus}

In All the Hues and Colors of the Rainbow

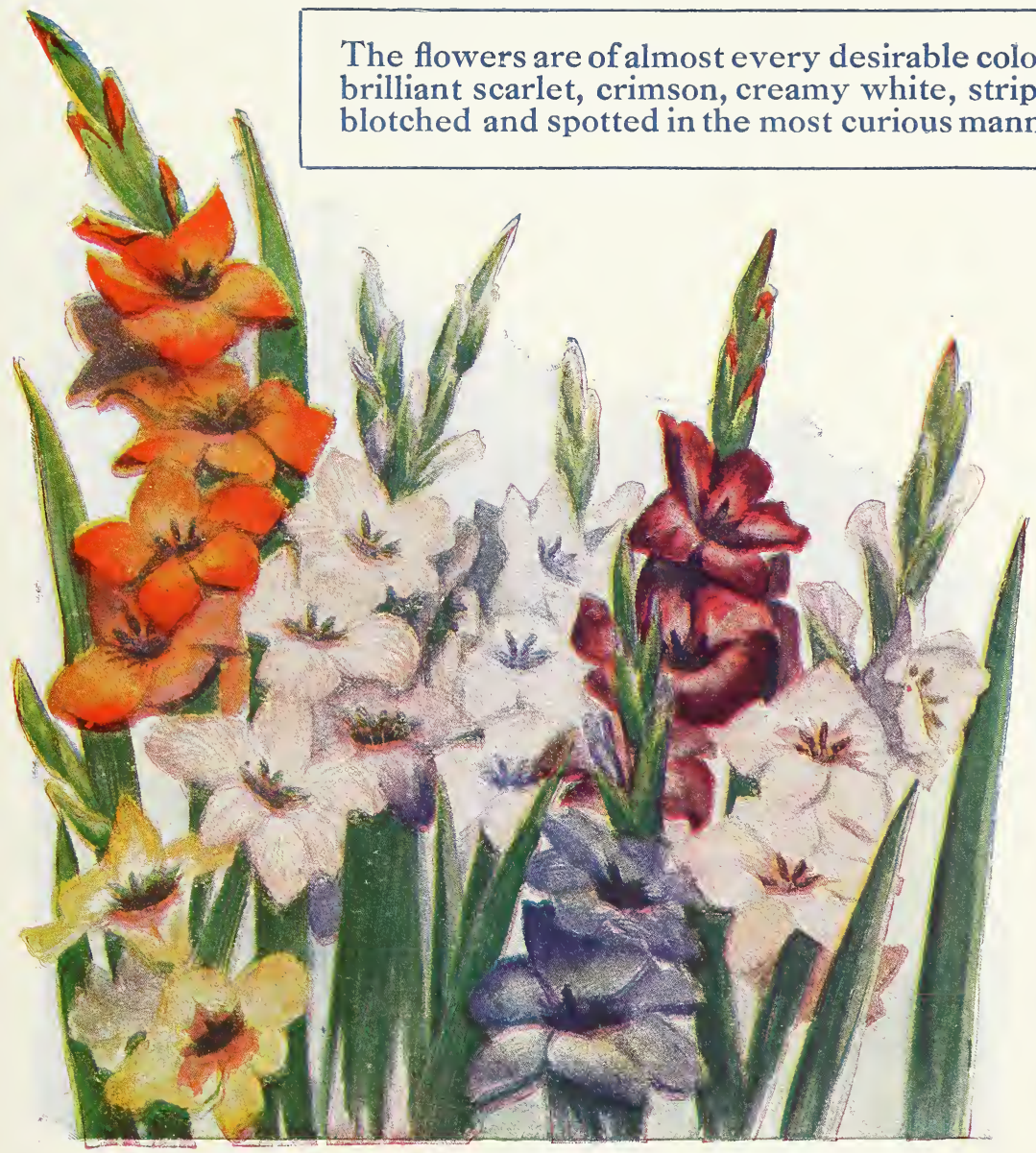

\section{Most Beautiful Flowering Summer Bulbs}

The Gladiolus, with its beautiful flowers clustered on tall spikes, which are two feet or more in height, and often several from the same root, is the most attractive of all the summer flowering bulbs, and deserves a place in every garden or lawn, as it is sure to flower and do well with very little care, and has no insect enemies or diseases.

We have been experimenting for years with Gladioli to obtain most distinct and showy varieties, and have now an assortment of these beautiful and popular summer flowering bulbs that is unrivaled for brilliancy and variety of coloring, strength and vigor of growth, flowers of exceptionally large size, and distinctive and attractive appearance.

Prices 5 cents each, 6 for 25 cents or 100 for $\$ 3.00$ post paid. 


\section{Spring and Fall 1916}

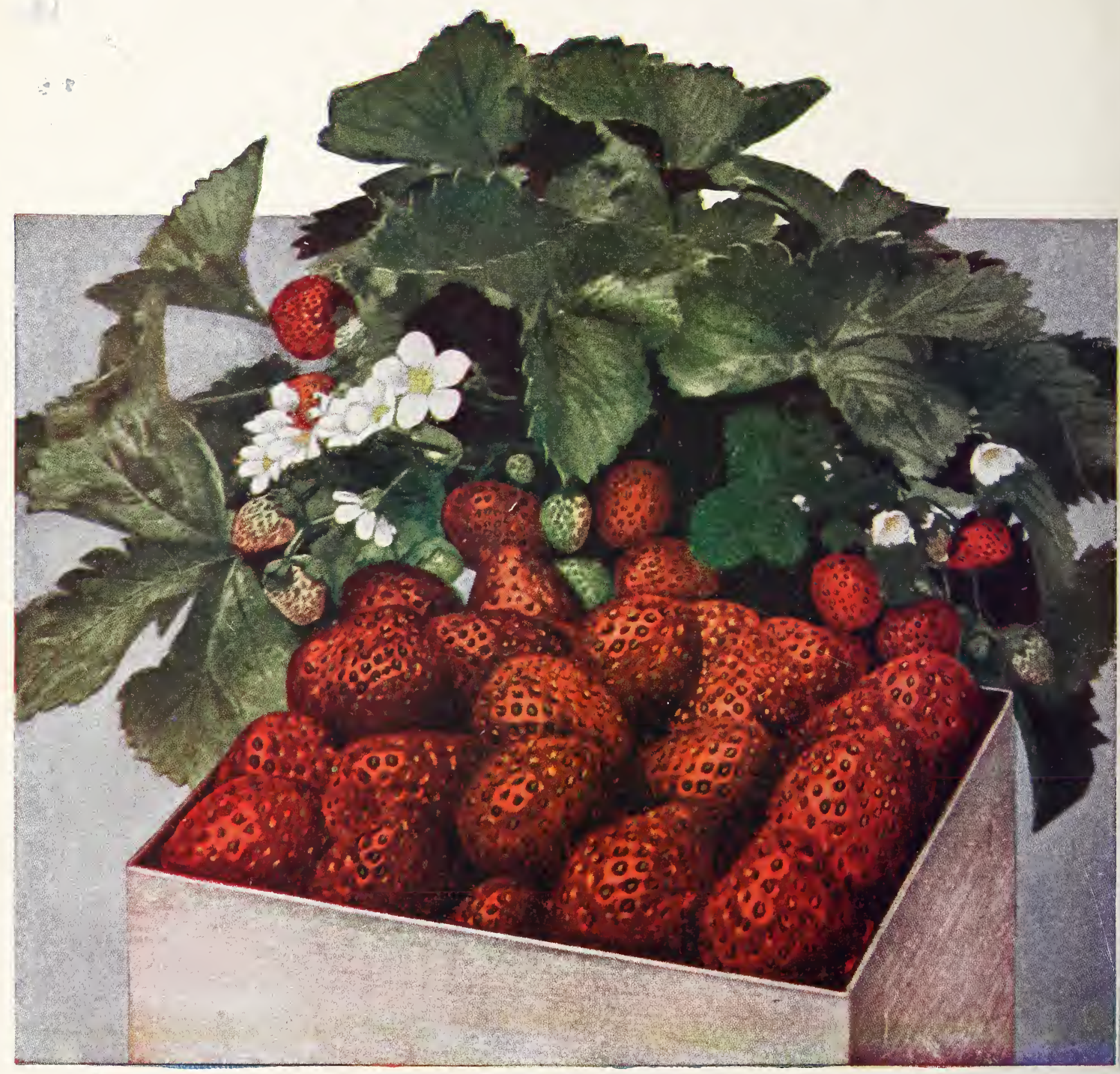

PROGRESSIVE EVERBEARING STRAWBERRY

\section{Fairbury Nurseries \\ C. M. HURLBURT, Prop.}

Fairbury, - Nebraska 